\title{
IMPACTOS DAS PRESSÕES AMBIENTAIS SOBRE A CONDUTA E O DESEMPENHO DA INDÚSTRIA BRASILEIRA DE CELULOSE
}

\author{
EMERSON MARTINS HILGEMBERG \\ Bacharel em Ciências Econômicas
}

Orientador: Prof. Dr. CARLOS JOSÉ CAETANO BACHA

Dissertação apresentada à Escola Superior de Agricultura "Luiz de Queiroz", Universidade de São Paulo, para obtenção do título de Mestre em Ciências, Área de Concentração: Economia Aplicada.

\author{
PIRACICABA \\ Estado de São Paulo - Brasil \\ Maio - 2000
}


Dados Internacionais de Catalogação na Publicação (CIP) DIVISÃO DE BIBLIOTECA E DOCUMENTAÇÃO - Campus “Luĩz de Queiroz"/USP

Hilgemberg, Emerson Martins

Impactos das pressões ambientais sobre a conduta e o desempenho da indústria brasileira de celulose / Emerson Martins Hilgemberg. - - Piracicaba, 2000.

$156 \mathrm{p}$.

Dissertaçāo (mestrado) - - Escola Superior de Agricultura Luiz de Queiroz, 2000. Bibliografia.

1. Comercializaçāo agricola 2. Exportação agricola 3. Impacto ambiental 4.

Indústria de celulose 5. Legislação ambiental 6. Mercado extemo 7. Oferta e demanda 1. Titulo

CDD 338.476762

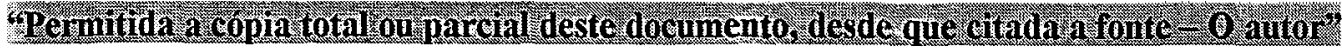


A meus pais, Gilberto (in memorian) e Teresinha e à minha esposa Cleise, amiga, companheira e grande amor da minha vida. 


\section{AGRADECIMENTOS}

Ao Prof. Carlos José Caetano Bacha, pela orientação competente e capacidade de organizar idéias, muitas vezes difusas, em um raciocínio coerente.

À minha esposa Cleise, pelo apoio em todos os momentos do Curso e da realização desta Dissertação. Minha gratidão e amor eternos.

Ao meu pai (in memorian) e à minha mãe, por ter cumprido de forma digna e responsável a difícil tarefa de educar, sozinha, seus dois filhos. À minha vó, pelo carinho e apoio. Ao Ricardo e à Patrícia, pelo incentivo e convívio sempre alegre.

Ao pessoal da República: ao Fábio, pelas partidas de basquete, invariavelmente por ele vencidas; ao Bruno, José, Marcelo e Fabiano pela paciência (!?) para suportar meus desafinados acordes.

Aos colegas do mestrado e do doutorado, em especial ao Paulo, pelos comentários e troca constante de idéias na fase de elaboração da disserțação.

À professora Heloísa Lee Burnquist, e aos professores Joaquim José Martins Guilhoto, Evaristo Marzabal Neves e Joaquim Bento de Souza Ferreira Filho, pelos úteis e precisos comentários, quando da apresentação do projeto de dissertação e da qualificação.

Aos funcionários do Departamento de Economia, Administração e Sociologia, em especial à Maielli, Luciane e Ligiane.

À CAPES e à UNICENTRO, por terem possibilitado o apoio financeiro para a realização deste trabalho.

Ao Prof. Fernando Franco Neto e à Prof. Sandra Mattos, do Departamento de Economia da UNICENTRO, pelo apoio e ajuda constante.

Aos colegas do Departamento de Economia da UEPG, em especial ao Prof. Hermes Higashi, pela troca de idéias e discussão de pontos importantes para $\circ$ desenvolvimento deste trabalho.

Finalmente, às empresas exportadoras de celulose, pelas informaçōes prestadas, as quais auxiliaram, em muito, a realização desta pesquisa. 


\section{SUMÁRIO}

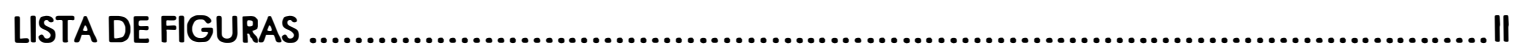

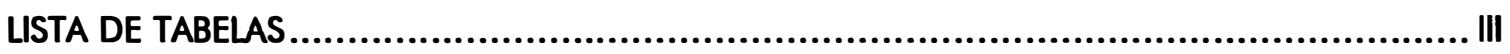

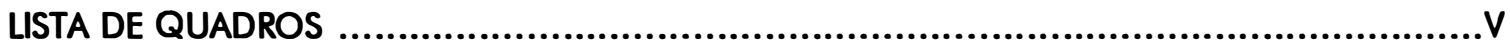

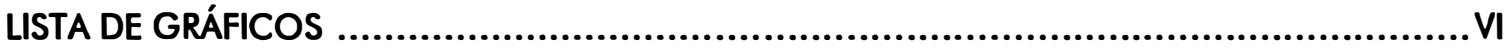

RESUMO

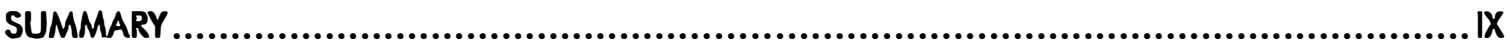

1 INTRODUÇĀO

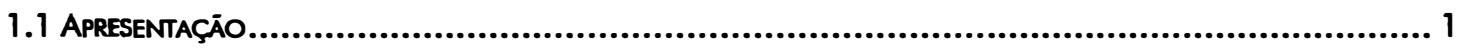

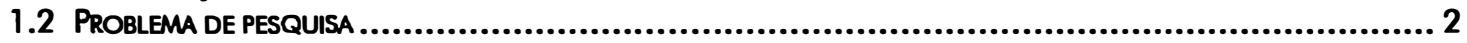

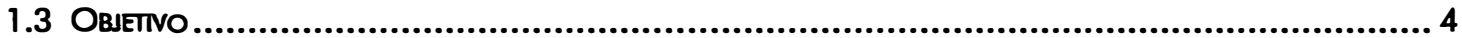

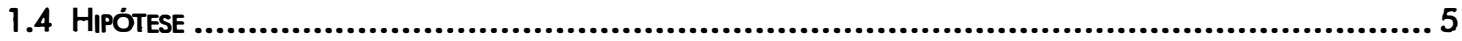

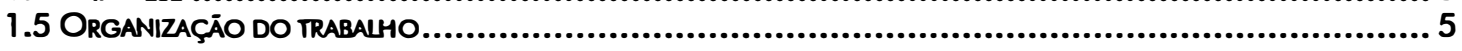

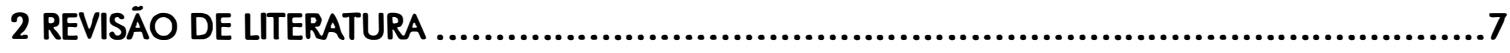

3 REFERENCIAL TEÓRICO E METODOLÓGICO .................................................14

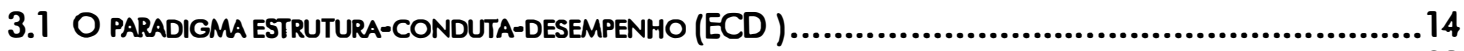

3.2 TEORIAS SOBRE COMÉRCIO INTERNACIONAL E SUAS UGAÇŌES COM A ORGANIZAÇĀO INDUSTRIAL ...................29

3.3 O CONCETO DE COMPETIIVIDADE ..................................................................................32

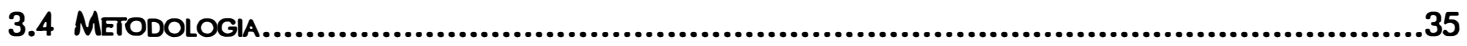

4 ALTERAÇŌES NAS CONDIÇŌES DE DEMANDA E OFERTA MUNDIAL DE CELULOSE ..........37

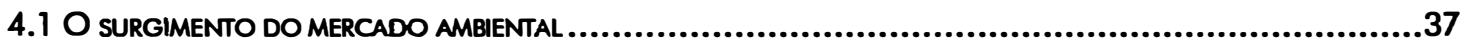

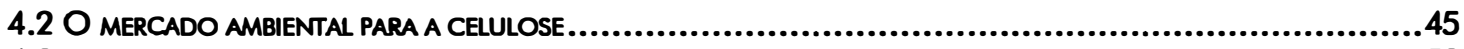

4.3 AS PRESSÖES AMBIENTAIS INCIDENTES SOBRE O PROCESSO DE PRODUÇĀO DA CELULOSE ................................53

5 EVOLUÇĀO DA INDÚSTRIA BRASILEIRA DE CELULOSE E A INSERÇĀO DO BRASIL NO

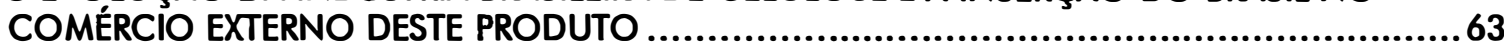

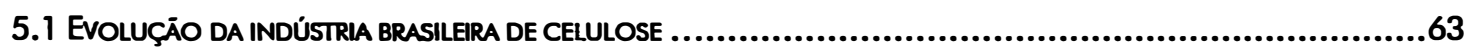

5.2 A PARTCIPAÇĀO DO BRASIL NO COMÉrCIO EXTERNO DE CELULOSE...............................................77

6 A ORGANIZAÇĀO ATUAL DA INDÚSTRIA BRASILEIRA DE CELULOSE ...........................86

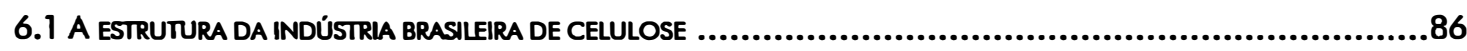

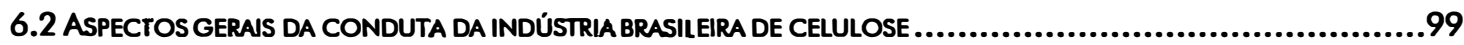

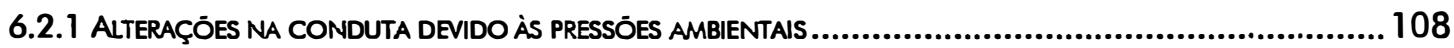

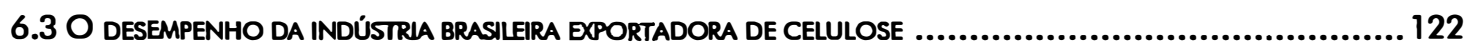

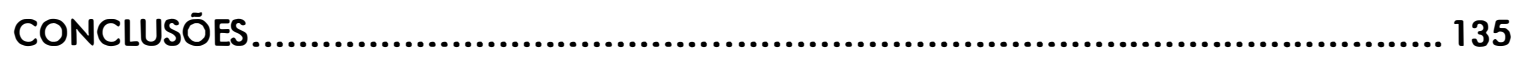

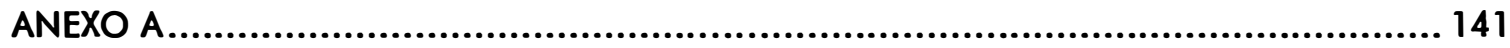

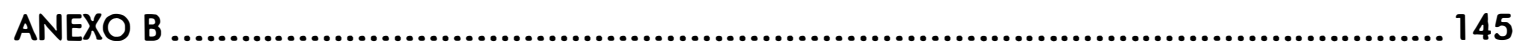

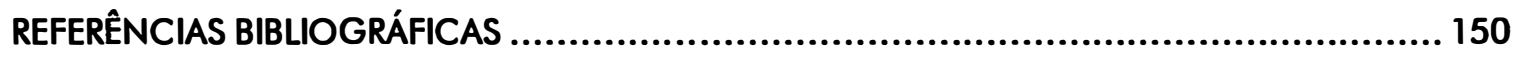




\section{LISTA DE FIGURAS}

Página

1 Relações entre estrutura, conduta e desempenho

2 Procedimento de seleção de produtos e desenvolvimento de critérios para o Ecolabel da União Européia

3 O processo de produção da celulose

4 Melhoramento contínuo sob a ISO 14001 


\section{LISTA DE TABELAS}

Página

1 Evolução da taxa de utilização de papel reciclado (TU) e dos índices de quantidade do consumo aparente de papel reciclado (CArec) e de celulose (CAcel) - índices com base em 1988

2 Evolução da produção de celulose (em milhões de ton.), segundo o processo de produção empregado. 1990 - 1998

3 Área aprovada para reflorestamento com recursos dos incentivos fiscais no período de 1967 - 1977

4 Principais produtores e exportadores de celulose de eucalipto no mundo em 1997

5 Maiores concorrentes das empresas brasileiras

6 Destino das exportações brasileiras de celulose (em mil toneladas) e participação percentual de cada país no total exportado pelo Brasil no período 1989 - 1999

7 Maiores compradores da celulose brasileira por empresa

8 Principais características dos maiores importadores de celulose do Brasil

9 Principais características da indústria de papel e papelão dos maiores importadores de celulose do Brasil

10 Evolução das principais características dos países exportadores de celulose

11 Principais produtores brasileiros de celulose - 1997

12 Segmentos de atuação dos principais grupos envolvidos na produção de celulose de mercado

13 Importância das preocupações ambientais na decisão de compra dos seus clientes

14 Importância relativa das pressões ambientais no comportamento estratégico das empresas

15 Importância das estratégias para enfrentar a questão ambiental

16 Áreas florestais certificadas pelo FSC 
17 Evoluçāo da distribuição percentual da produção segundo o processo de branqueamento utilizado

18 Capacidade de produção por tipo de celulose em 1999 (ton./ano)

19 Empresas brasileiras exportadoras de celulose certificadas no padrão ISO 14001 e data de obtenção do certificado

20 Desempenho ambiental típico das plantas de celulose química $(\mathrm{kg} / \mathrm{tsa})$

21 Participação percentual de celulose brasileira na quantidade total importada por países selecionados no período 1980 - 1998 


\section{LISTA DE QUADROS}

Página

1 Três etapas na formação do mercado ambiental global 38

2 Programas de Rotulagem Ambiental 43

3 Caracterização das empresas brasileiras exportadoras de celulose 89-90

4 Principais projetos de investimento em produção de papel e celulose no Brasil 105 


\section{LISTA DE GRÁFICOS}

Página

1 Produção de celulose e fibras recicladas (em ton.) no mundo. 1980 - 1998

48

2 Consumo aparente de fibras recicladas (CA) e valor unitário (VU) em US\$/ton. da celulose na União Européia. 1980 - 1998

3 Desembolsos do BNDES para o setor de celulose e papel em relação aos desembolsos totais do Banco (valores em \%). 1985 - 1994

4 Evolução da produção de celulose no Brasil no período de 1961 - 1998 (em toneladas) 76

5 Evolução das exportaçōes brasileiras de celulose no período de 1970 - 1998 (em toneladas)

6 Evolução da parcela de importaçōes de cada país sobre o total importado no mundo no período 1980 - 1998

7 Market share da exportação brasileira de celulose no ano de 1998

8 Tamanho médio das fábricas de celulose e pastas (capacidade média de produção anual) 104

9 Market share do Brasil na exportação de celulose no mundo

10 Comportamento do preços da celulose (US\$/ton.) no período de jan. 1990 a set. 1998

11 Evolução dos lucros da Aracruz (R\$) e do preço (R\$/ton.) da celulose. 1990 - 1998

12 Evolução dos lucros da Riocell (R\$) e do preço (R\$/ton.) da celulose. 1990 - 1998

13 Evolução dos lucros da Cenibra (R\$) e do preço (R\$/ton.) da celulose. 1990 - 1998

14 Evolução dos lucros da Jari (R\$) e do preço (R\$/ton.) da celulose. 1991 - 1998 


\title{
IMPACTOS DAS PRESSÕES AMBIENTAIS SOBRE A CONDUTA E 0 DESEMPENHO DA INDÚSTRIA BRASILEIRA DE CELULOSE
}

\author{
Autor: EMERSON MARTINS HILGEMBERG \\ Orientador: Prof. CARLOS JOSÉ CAETANO BACHA
}

\section{RESUMO}

O objetivo desta dissertação é analisar os impactos das pressōes ambientais sobre a conduta e o desempenho, especificamente sobre a competitividade, da Indústria Brasileira de Celulose. Embora existam estudos semelhantes, este trabalho apresenta o problema de uma forma mais "aplicada", isto é, não se limita a discutir a competitividade do setor tendo como ponto de referência apenas os modelos teóricos abstratos. Sempre que possível, apresentam-se dados estatísticos que dão base a determinadas idéias, uma vez que a metodologia empregada consiste, fundamentalmente, em uma análise tabular e gráfica de dados secundários e primários (estes últimos obtidos por meio de uma pesquisa de campo, realizada por intermédio de questionários). Assim, após estabelecer o referencial teórico, analisam-se as alteraçōes nas condiçōes de demanda e oferta mundial de celulose, enfocando-se, primeiramente, - surgimento do mercado ambiental e, em seguida, a sua especificidade para a celulose, bem como as pressōes ambientais sobre o processo de produção. Em seguida, analisa-se a evolução da indústria brasileira de celulose, mostrando que, desde sua gênese, o apoio governamental, por meio do BNDES, foi crucial para a realização do objetivo de criar no país uma indústria produtora de celulose competitiva em nível mundial. Atenção também é dedicada à participação do Brasil no comércio externo de celulose, enfocando-se as características principais dos outros grandes produtores mundiais, dos grandes países consumidores, bem como as principais características dos maiores compradores da celulose brasileira. 
Passa-se, então, à análise da organização atual da indústria brasileira de celulose e dos aspectos gerais da sua conduta, mostrando que ela é fortemente condicionada pelo mercado internacional. Neste particular, consideram-se o modo pelo qual os preços da celulose são estabelecidos, a busca por economias de escala cada vez maiores, por intermédio de aumentos de capacidade, os processos de reestruturação produtiva, por meio de fusões, e a política de pesquisa e desenvolvimento. Finalmente, atenção especial é dada à mudança na conduta das empresas diante das pressōes ambientais originadas dos principais mercados consumidores, as quais, dada a sua intensidade, acabaram por estabelecer uma nova best practice no mercado mundial de celulose, forçando todas as empresas que atuam neste mercado a se adequar a determinados padrōes de performance ambiental. A eficiência em alcançar tais padrões estabelece, por sua vez, o desempenho da indústria, o qual é avaliado pela sua capacidade de manter, ou até mesmo aumentar, seu market share nos principais mercados consumidores, que caracterizam-se por uma exigência de altos níveis de desempenho ambiental. Assim, o trabalho termina por concluir que as empresas brasileiras exportadoras de celulose foram capazes de responder às pressões ambientais, mantendo sua competitividade no mercado internacional logrando, até mesmo, aumentar sua participação nas regiōes onde as preocupações ambientais são maiores. 


\title{
IMPACTS OF THE ENVIRONMENTAL PRESSURES ON THE CONDUCT AND PERFORMANCE OF THE BRAZILIAN PULP INDUSTRY
}

\author{
Author: EMERSON MARTINS HILGEMBERG \\ Adviser: Prof. CARLOS JOSÉ CAETANO BACHA
}

\section{SUMMARY}

The aim of this research is to analyze the impacts of the environmental pressures on the Brazilian pulp industry conduct and performance, specifically on its competitiveness. Although similar studies exist, this work presents the problem in a more applied way, that is, it is not limited to discuss the competitiveness of the industry just using abstract models. Whenever possible, the statistical data that give base to certain ideas are presented, since the methodology adopted consists, fundamentally, in an tabular and graphical analysis, using published and primary data. The last ones were obtained from questionnaires. Thus, after establishing the theoretical framework, the changes in the world conditions of demand and supply for pulp are analyzed, being focused, first, the appearance of the environmental market and, soon after, its specificity for the world market of pulp, as well as the environmental pressures on the production process. In sequence, the evolution of the Brazilian industry of pulp is analyzed, showing that, from its genesis, the public support, provided by BNDES, was crucial for the accomplishment of the objective of creating at the country a competitive pulp industry in the world market. Attention is also dedicated to the evolution of the Brazilian exports of pulp, being also focused the main characteristics of the other major world producers, of the great consuming countries, as well as the main characteristics of the largest buyers of the Brazilian pulp. 
Following this, the work carries out an analysis of the current organization of the Brazilian pulp industry and the general aspects of its conduct, showing that the last have been conditioned strongly by the international market. In this matter, they are considered the way for which the pulp prices are established, the constant search for scale economies, through capacity increases, the processes of productive restructuring, by means of mergers and the R\&D policy. Finally, special attention is given to the change in the conduct of the companies as a reaction to the environmental pressures from the main consuming markets, the ones which given its intensity, ended for establishing a new best practice in the world market of pulp, forcing all the companies that act in this market to accomplish certain patterns of environmental performance. The efficiency in reaching such patterns establishes the conduct of the industry. The last one is evaluated by the capacity of the Brazilian pulp industry to maintain, or even increasing, its market share in the main consuming markets. These markets are characterized by high demand levels of environmental performance. Thus, the work ends up concluding that the Brazilian pulp exporters were capable to answer to the environmental pressures, maintaining its competitiveness in the market and achieving, even, to increase its participation in the countries where the environmental demands are larger. 


\section{INTRODUÇÃO}

\subsection{Apresentação}

A indústria brasileira de celulose é constituída pelo conjunto de empresas situadas no território nacional que elaboram pasta de madeira. Essa pasta pode ser obtida através do cozimento dos cavacos de madeira com produtos químicos (que dá origem à celulose, propriamente dita), através da fricção mecânica dos cavacos, ou através da combinação desses dois processos.

Pelo fato da celulose representar mais de $90 \%$ do total produzido de pasta de madeira no Brasil, é comum usar o termo celulose para se referir ao conjunto de todas as pastas de madeira produzidas. Daí a expressão Indústria Brasileira de Celulose englobar tanto as empresas produtoras de celulose como as que elaboram outros tipos de pastas de madeira. Além disso, há grande integração vertical entre a produção de celulose e de papel. Por conta disso, quando se considera a produção conjunta desses bens, utiliza-se o termo setor de papel e celulose.

O Brasil vem se tornando um dos principais países exportadores de celulose do mundo. Desde o final da década de 70, a produção e a exportação de celulose apresentam um crescimento significativo, graças, sobretudo, ao I Plano Nacional de Papel e Celulose (PNPC), concebido dentro da estratégia de busca da autosuficiência em vários setores da economia brasileira proposta no II Plano Nacional de Desenvolvimento. 
Não obstante, a indústria mundial de celulose vem enfrentando uma série de pressões ambientais tanto do lado de sua matéria-prima principal, no que diz respeito ao problema do desmatamento e da perda da biodiversidade, como no lado dos processos produtivos e impactos no meio ambiente causados pelos processos de branqueamento.

Esta pesquisa procura analisar como a indústria brasileira de celulose se viu obrigada, diante de tais pressões, a alterar sua conduta e como este processo alterou seu desempenho, particularmente, a sua competitividade.

\subsection{Problema de pesquisa}

A celulose e as demais pastas prestam-se não só para a fabricação de papel mas também para vários outros produtos. A celulose solúvel, por exemplo, possui aplicações na indústria química, farmacêutica e têxtil. Estas aplicações, no entanto, representam um volume pouco significativo em relação à sua utilização para a fabricação de papel.

A celulose de mercado, foco de análise deste trabalho, ao contrário da produzida pelas empresas integradas, é vendida a terceiros através de contratos ou no mercado spot. $O$ mercado de celulose engloba duas categorias principais, a saber, fibras virgens e celulose reciclada, manufaturada a partir do papel reciclado. Contudo, neste trabalho, o objeto de estudo é a celulose de fibras virgens.

O Brasil possui uma posição competitiva no mercado internacional graças, principalmente, à disponibilidade e velocidade de crescimento das plantações florestais.

Aqui, as plantações de eucalipto podem ser cortadas após, em média, sete anos da data do plantio. Na Indonésia, por exemplo, o corte de acácia e eucalipto se dá em oito anos. Na península ibérica, o corte de eucalipto é feito de doze a quinze anos após o plantio. Na América do Norte e Escandinávia, outras espécies equivalentes no uso (hardwood) só podem ser cortadas vinte a noventa anos após o plantio.

Além disso, o custo da terra é relativamente baixo no Brasil e a indústria investe em Pesquisa e Desenvolvimento (P\&D) na área de biotecnologia e manejo 
florestal. A oferta de energia (principalmente hidrelétrica) a custos competitivos, a escala de produção (fruto da estratégia de desenvolvimento governamental) e os baixos custos de mão-de-obra também contribuem para a competitividade da celulose brasileira no mercado externo.

No entanto, outro fator condicionante da competitividade de um país no mercado internacional de celulose é a questão ambiental.

Os problemas ambientais relacionados à indústria de celulose envolvem questões como a perda de biodiversidade nos plantios homogêneos e o desmatamento, além dos problemas de controle da polvição da água e do ar durante o processo industrial.

Diante da evidência crescente da temática ambiental, os produtores de celulose passaram, cada vez mais, a enfrentar pressōes por parte, inicialmente dos consumidores e das organizações não-governamentais, e, depois, por parte dos governos. Todos eles passaram a demandar uma série de práticas ambientais por parte da indústria, baseadas na idéia do desenvolvimento ambientalmente sustentável.

As exigências ambientais acabaram por evoluir para o estabelecimento de certos padrões de performance ou para a adoção de determinadas práticas que conferissem ao produtor um selo ou certificado capaz de informar ao consumidor que o produto fora produzido por intermédio de processos ambientalmente sustentáveis.

Especificamente quanto à celulose, os critérios básicos pelos quais o desempenho ambiental é avaliado dizem respeito, basicamente, à forma de manejo florestal, ao uso de cloro no branqueamento e, fundamentalmente, a padrões de emissões químicas e biológicas, principalmente no que diz respeito à presença, no efluente, de compostos orgânicos halogenados (AOX).

Além disso, frente aos critérios de certificação estabelecidos, a indústria de celulose de fibras virgens passou a enfrentar a competição crescente das fibras secundárias (recicladas) tidas, por alguns dos principais compradores, como ambientalmente mais saudáveis. 
Deste modo, todas essas pressões ambientais levaram nossa indústria a alterar sua conduta, visando gerar produtos ambientalmente corretos, sob o risco do país perder os principais mercados para o seu produto. A questão central, portanto, é saber o quão efetiva foi a mudança de conduta das empresas e quais os seus impactos sobre o desempenho da Indústria Brasileira de Celulose.

\subsection{Objetivo}

O objetivo geral desta pesquisa é analisar os impactos das pressões ambientais sobre a conduta e o desempenho, especificamente sobre a competitividade, da Indústria Brasileira de Celulose.

Como objetivos específicos procurar-se-á:

A. sintetizar e adaptar um referencial teórico e metodológico que permita analisar, de forma ordenada, as inter-relaçōes entre mudanças no comportamento da demanda por um produto e a resposta das empresas de uma determinada indústria, contemplando o fato de que essas empresas atuam num mercado mundial e têm de ser competitivas globalmente;

B. analisar as alteraçōes nas condiçōes mundiais de demanda e oferta da celulose, provocadas pelas pressões ambientais;

C. caracterizar a evolução da indústria brasileira de celulose e a inserção do Brasil no comércio internacional desse produto;

D. analisar a organização atual da indústria brasileira de celulose; e,

$\rightarrow$ E. caracterizar a influência das pressões ambientais sobre a conduta da indústria brasileira de celulose, bem como as modificações ocorridas no seu desempenho por conta de tais pressões. 


\subsection{Hipótese}

A hipótese deste trabalho é que as mudanças de atitudes dos consumidores em relação às práticas ambientais das empresas, o estabelecimento de esquemas de certificação e a tendência a uma maior utilização de fibras recicladas, acabam por estabelecer uma nova best practice no mercado internacional de celulose, definindo um novo padrão internacional de concorrência que atua de forma a pressionar todos os competidores no sentido de incorporar o progresso técnico, por intermédio de inovações, sob o risco de não serem capazes de manter sua participação no mercado.

\subsection{Organização do trabalho}

Este trabalho é dividido em seis capítulos, além desta introdução. $O$ segundo capítulo faz um revisão da literatura sobre o setor de papel e celulose, enfocando os trabalhos que trataram da evolução desse setor no Brasil, em especial, sua evolução tecnológica, tratando da relação entre a regulação ambiental e o desenvolvimento tecnológico. Consideram-se também os trabalhos que tratam da competitividade da indústria brasileira de celulose e a importância dos esquemas de certificação ambiental e sua possível utilização como barreira não tarifária às exportações do Brasil.

O capítulo três, por sua vez, estabelece o referencial teórico e metodológico que dará base a este estudo, operacionalizando o modelo estruturaconduta-desempenho para a análise da organização da indústria brasileira de celulose. Além do modelo propriamente dito, é considerado também o conceito de competitividade, o qual também será importante na avaliação do desempenho exportador da indústria. Neste capítulo, também, é exposta a metodologia utilizada para a realização desta dissertação.

O capítulo quatro trata das alterações nas condições mundiais de demanda e oferta por celulose, analisando a formação do mercado ambiental, sua especificidade no caso da celulose, a qual envolve uma tendência crescente à utilização 
de fibras recicladas e uma exigência, cada vez maior, da substituição do cloro elementar nos processos de branqueamento. $O$ intuito desse capítulo é ressaltar as novas condições de demanda e oferta que afetam a estrutura, conduta e desempenho da indústria brasileira de celulose.

O capítulo cinco mostra a evolução histórica da indústria brasileira de celulose, mostrando que seu desenvolvimento foi, em grande parte, condicionado pela alteração no cenário mundial de demanda e oferta pelo produto e pelas políticas públicas que tinham, desde o estabelecimento das primeiras empresas, o objetivo de torná-las competitivas em nível do mercado mundial. Considera-se também a inserção do Brasil no mercado internacional de celulose, analisando a evolução das exportações brasileiras de celulose, enfocando-se o mercado para as exportações de celulose, apresentando-se os principais países produtores e os principais países consumidores no mundo, além das características dos principais compradores da celulose brasileira.

O capítulo seis trata da estrutura atual da indústria brasileira de celulose, dos aspectos gerais de sua conduta, bem como das mudanças nesta conduta, causadas pelas pressões ambientais. Por fim, este capítulo mostra o desempenho da indústria brasileira de celulose.

O capítulo sete contém as conclusões do trabalho. 


\section{REVISÃO DE LITERATURA}

A produção de celulose e de outros tipos de pastas de madeira no Brasil é feita por empresas não-integradas e por empresas integradas. As empresas nãointegradas são aquelas que produzem celulose para ser vendida no mercado (a chamada celulose de mercado). As empresas integradas, por sua vez, produzem celulose para ser, prioritariamente, transformada em papel pela própria empresa.

Por conta da grande representatividade das empresas integradas de celulose e papel, vários estudos se direcionam para examinar o setor de papel e celulose no Brasil.

Alguns estudos já foram realizados sobre a evolução do setor de papel e celulose bem como dos fatores determinantes desta evolução, caso de Paladino (1985) e Soto (1992).

Paladino (1985) realizou um estudo sobre a evolução tecnológica dos processos de fabricação de papel desde a forma artesanal até a grande indústria automatizada contemporânea. Além disso, tratou também da estruturação da indústria do papel no Brasil.

Mendonça Jorge (1992) estudou o processo de constituição e as principais estratégias das empresas produtoras de celulose de mercado, utilizando, para tanto, a noção de "padrão eucalipto".

Segundo o autor, tal noção "procura abranger o padrão de concorrência vigente no setor de celulose de mercado, cuja estrutura de mercado predominante é do tipo oligopólio concentrado, [bem como] as particularidades do movimento concreto de 
constituição deste mercado no contexto da industrialização brasileira" (1992, p. 92). Ainda segundo ele, "embora não seja possível fazer uma analogia direta, é sugestiva também a idéia de pensar o conceito de 'Padrão Eucalipto' como a construção de paradigma tecnológico-econômico, onde determinados procedimentos são eleitos pelas empresas e passam a ser rotinizados. Em outras palavras, existe uma convergência das decisões empresariais para um padrão determinado" (1992, p. 92, rodapé).

As principais conclusões deste trabalho foram as seguintes:

I. " (...) a produção de celulose só se viabilizou no momento em que se desenvolveu a tecnologia de fabricação de celulose de fibra curta de eucalipto e quando o BNDES, através do financiamento aos investimentos, iniciou seu apoio ao setor" (1992, p. 149 - 150). Desta forma, "a consolidação da produção de celulose foi (...) fruto da articulação entre políticas públicas (fomento florestal, desenvolvimento de tecnologia de produção, programas de capacitação técnica, financiamentos), em um contexto de rápida expansão do mercado interno e em menor grau, das exportações"(1992, p. 150);

II. "No plano estratégico, as empresas souberam aproveitar as oportunidades oferecidas pelo Estado para estabelecerem condições vantajosas de operação (base florestal adequada, equipamentos atualizados, matriz energética baseada em recursos florestais) e para melhorar a qualidade de seus produtos e processos produtivos, em particular, quanto ao controle ambiental, formas de comercialização e construção de infra-estrutura nas áreas onde as empresas se instalaram" (1992, p. 151);

III. as principais desvantagens competitivas das empresas dizem respeito à (1) dificuldade de encontrar financiamento para investimentos que sejam compatíveis com o prazo de maturação dos projetos, o que implica numa concentração da demanda por crédito junto ao BNDES, (2) a crescente exigência de padrões de qualidade cada vez 
mais elevados no mercado internacional e, (3) o crescimento do protecionismo tecnológico dos países desenvolvidos, através das vendas de 'pacotes' tecnológicos aos países periféricos, o qual acarreta um aumento da dependência tecnológica e um baixo dinamismo e reduzida rentabilidade na indústria de celulose;

IV. as estratégias das empresas privilegiam a expansão de capacidade ao invés de uma maior preocupação com o desenvolvimento tecnológico e uma maior aproximação com institutos de pesquisa e empresas produtoras de bens de capital.

Soto (1992) propõe uma interpretação da constituição do Complexo Florestal no Brasil como sendo o resultado histórico de um padrão de relacionamento neocorporativista entre interesses privados e o Estado'. O autor procura demonstrar que o complexo não é regulado por mecanismos de mercado e sim por uma grande variedade de arranjos entre os interesses privados e o Estado. Desta forma, a estrutura e dinâmica do Complexo Florestal são o resultado histórico de um processo de concertación de interesses entre grupos privados e as agências governamentais, em particular o BNDES.

Outros estudos analisaram a organização do setor de papel e celulose no que se refere à sua organização. Zayen (1986) utilizou o paradigma estrutura-condutadesempenho para avaliar a estrutura e o desempenho do setor de papel e celulose no Brasil.

Higashi (1993), utilizando o arcabouço "incrementalista-evolucionista", estudou o comportamento estratégico das empresas líderes na indústria brasileira do papel, concluindo, dentre outras coisas, que:

\footnotetext{
'Segundo o autor, "o intercâmbio político neocorporativista envolve um processo de duplo sentido; num deles, a representação dos interesses privados procura influenciar as autoridades do governo com o propósito de provocar decisōes que the favoreçam. Mas também, no sentido inverso, as autoridades governamentais procuram influenciar na articulação dos interesses privados. Ambos os sentidos convergem para constituírem um processo de negociação das políticas públicas (1992, p. 14-5)."
} 
I. algumas indústrias buscam uma estratégia de desenvolvimento imitativa e outras um estratégia de desenvolvimento dependente;

II. o núcleo de progresso técnico localiza-se na indústria de bens de capital sob encomenda, pois são elas as firmas capazes de conceber, construir e testar os protótipos de plantas-piloto de equipamentos e processos; e

III. o aprendizado tecnológico local na área florestal e industrial resultou de um esforço conjunto das empresas componentes da indústria, por uma indústria nacional de bens de capital (Pilão) e pelas bridge institutions, com o Estado assumindo todos os custos e riscos do processo de inovação.

Mais recentemente, porém, observa-se o surgimento de trabalhos investigando a influência das pressōes ambientais sobre o desenvolvimento tecnológico do setor de papel e celulose.

Silva (1995) procura compreender a relação entre a regulação ambiental e o desenvolvimento tecnológico. Para tanto, faz uso do referencial teórico shumpteriano, segundo o qual a concorrência atua como um mecanismo indutor de desequilíbrios nos vários mercados, uma vez que a vantagem competitiva é obtida através das atividades de inovação, as quais procuram obter vantagens tecnológicas não-apropriáveis pelos concorrentes. Desta forma, a busca constante de valorização dos capitais exige uma multiplicidade de estratégias e formas de concorrência que atuam no sentido de promover a constante mudança técnica, reestruturando permanentemente os mercados, a base produtiva e suas inter-relaçōes.

Todo este processo de "destruição criativa" se processa dentro de um determinado paradigma tecnológico, o qual define quais são os problemas relevantes e quais os conhecimentos específicos relacionados à sua solução, sendo que a direção do avanço do paradigma tecnológico é chamada de "trajetória tecnológica".

No que se refere à indústria de celulose, o autor aponta quatro forças responsáveis pela reestruturação dos mercados, a saber: legislaçōes restritivas de 
mercado a determinados processos ou produtos, ou de incentivo a outras rivais; mudanças nas preferências dos consumidores; estratégias de empresas que visam antecipar-se às duas forças anteriores, buscando firmar uma imagem institucional favorável em relação ao meio ambiente; além da própria dinâmica intrínseca do paradigma tecnológico.

Estas mudanças representam a quebra de um determinado horizonte de regularidade nos padrōes técnico-produtivos e de consumo na indústria mundial de celulose. Por outro lado, o processo de concorrência intercapitalista faz com que as empresas busquem novos produtos, novos processos, novos mercados, novas fontes de matéria-prima ou novas formas organizacionais que possibilitam lucros extraordinários e uma redefinição do mercado em favor da empresa inovadora. É desta forma que o processo inovativo da indústria mundial de celulose se processa, com as empresas esforçando-se para se distanciar dos demais competidores.

Corazza (1996), fazendo uso do enfoque evolucionista, também analisa como a problemática ambiental repercute sobre as estratégias decisórias do setor de papel e celulose, particularmente no que se refere aos processos de inovação e capacitação tecnológica.

Tal como Silva (1995), a autora também argumenta que "a problemática ambiental tende a ser incorporada pelas estratégias inovativas e de capacitação não apenas como resposta a instrumentos coercitivos de controle ambiental, mas também como ação voluntária para o aproveitamento de oportunidades tecnológicas para a construção de vantagens competitivas" (Corazza, 1996, p. 127). No entanto, a contribuição principal desta autora vai no sentido da identificação dos vetores de demandas ambientais na indústria de celulose.

Castilho (1994), por sua vez, analisa as barreiras não-tarifárias impostas às exportações da celulose brasileira por conta do recrudescimento das pressōes ambientais. O objetivo desta política, segundo seus proponentes, seria induzir mudanças na gestão dos problemas ambientais de outros países, porém, em alguns casos, os argumentos ambientais são utilizados com fins protecionistas: "medidas que visam impor padrões nacionais a outros países ou que discriminam contra importações 
desconsideram as diferenças sociais, econômicas e geográficas. Os tratamentos dados ao produto doméstico e ao produto importado devem ser idênticos, impondo-se a estes últimos apenas restrições que digam respeito ao país importador, isto é, sobre os efeitos deletérios do consumo e disposição de bens" (Castilho, 1994, p. 96).

Há ainda trabalhos preocupados com a competitividade da indústria brasileira de celulose tais como BNDES (1993), Medeiros \& Fontes (1994), Fonseca (1995) e Pizzol \& Bacha (1998).

BNDES (1993) é um estudo abrangente que trata da competitividade do complexo celulose, papel e gráfica e propōe uma série de políticas para ele. Medeiros \& Fontes (1994) utilizaram o conceito de constant market share para determinar as principais fontes de crescimento das exportaçōes de celulose de cinco países selecionados $^{2}$ e concluíram que o crescimento das exportaçōes brasileiras de celulose no período de 1982 a 1991 se deveu a fatores internos que elevaram nossa competitividade, enquanto o crescimento das exportações de celulose dos outros países analisados foi determinado por elementos de natureza exógena (crescimento da renda nos mercados compradores e crescimento do comércio mundial de celulose).

Fonseca (1995) investiga como os novos processos e métodos de produção de celulose estão mudando o perfil tecnológico das plantas industriais, usando o Brasil como referência para o resto da América Latina.

Pizzol \& Bacha (1998) fazem um apanhado dos principais aspectos da indústria de celulose no Brasil, investigando sua evolução, a dinâmica da produção, consumo, importaçōes e exportaçōes. Esse artigo também compara os custos de produção de celulose entre o Brasil e seus concorrentes no mercado mundial, além de caracterizar a situação das pressões ambientais no mundo.

Contudo, os trabalhos acima comentados não avaliaram como as pressões ambientais acabaram por afetar o desempenho da indústria brasileira, em especial sua competitividade internacional, e restringiram-se a caracterizar a mudança

\footnotetext{
${ }^{2}$ Brasil, Canadá, EUA, Suécia e Finlândia.
} 
de conduta somente pelo aspecto da mudança do processo produtivo, sem considerar outras estratégias das empresas.

Desta forma, esta dissertação procurará contribuir no sentido de uma compreensão mais ampla do comportamento estratégico da indústria brasileira exportadora de celulose, particularmente diante das pressões ambientais existentes nos grandes mercados consumidores. 


\section{REFERENCIAL TEÓRICO E METODOLÓGICO}

Para que se torne possível a análise do impacto das pressōes ambientais sobre a conduta e o desempenho da indústria brasileira de celulose é necessário, em primeiro lugar, delimitar a teoria que servirá de referência a este estudo.

Para atender o propósito desta dissertação é preciso abordar como elementos das condiçōes básicas da demanda (por exemplo, métodos de compra) e de políticas governamentais (legislação ambiental, política de comércio, etc.), que expressam as pressōes ambientais, afetam a conduta das empresas. Para tanto, utilizase o paradigma estrutura-conduta-desempenho (ECD) para avaliar como as pressões ambientais levaram as empresas de celulose a alterar suas estratégias quanto a propaganda, P\&D, investimentos, entre outros. A partir desta mudança de estratégia e, por conseguinte, de comportamento, avaliam-se os impactos sobre a competitividade - avaliada pela eficiência produtiva e alocativa - da indústria. $O$ paradigma ECD é exposto no item 3.1.

Além disso, dado que este trabalho analisa a competitividade de uma indústria no mercado externo, é importante verificar como se estabelece a relação entre teorias de comércio internacional e organização internacional (item 3.2.) e como a competitividade no mercado internacional deve ser considerada (item 3.3).

\subsection{O paradigma estrutura-conduta-desempenho (ECD)}

A organização industrial (OI) consiste no estudo da estrutura das firmas e mercados e de suas interaçōes, preocupando-se em explicar como as atividades produtivas harmonizam-se com a demanda por bens e serviços através de mecanismos 
tais como o mercado, e como variações e imperfeições no mecanismo de organização afetam o sucesso em satisfazer as necessidades de uma economia (Carlton \& Perloff, 1994, p.2; Scherer \& Ross, 1990, p. 1).

Dito de outra forma, a proposição fundamental da Ol é que a sociedade deseja um bom desempenho dos produtores de bens e serviços. Assim, ela procura verificar como os mecanismos de mercado funcionam, procurando também identificar quando este mecanismo pode falhar e como ele se ajusta, ou pode se ajustar para atingir um desempenho que se aproxime de algum padrão ideal (Scherer \& Ross, 1990,* p. 2).

Por isso, Koch (1980, p.1) define a Ol como sendo um estudo teórico e empírico de como a estrutura da organização e a conduta dos vendedores e compradores afetam o desempenho e o bem-estar econômicos.

Tal definição deriva da abordagem estrutura-conduta-desempenho (ECD) concebida originalmente por Mason no final da década de 30 e que se constitui em uma importante ferramenta de análise da organização industrial.

\section{O SENTIDO DE DETERMINAÇĀO}

No modelo inicial do paradigma ECD, a hipótese era a de que a estrutura determinava a conduta da empresa e esta, por sua vez, definia o desempenho. A estrutura, por sua vez, dependia de condições básicas de oferta e demanda, tais como tecnologia e demanda por um produto. Para Mason (1939, p. 66), o problema econômico era explicar, através de um exame da estrutura dos mercados e da organização das firmas, diferenças em relação às práticas competitivas, incluindo políticas de preço, produção e investimento. Bain (1968, p.3) afirma que, em geral, o que determina o desempenho de uma empresa é, primeiro, a organização ou estrutura de uma indústria (ou grupo de empresas competidoras) que restringe e canaliza as atividades da empresa e seus resultados e, segundo, a conduta da empresa (suas políticas, práticas e mecanismos) para ajustar-se nos mercados em que ela participa. 
Embora no curto prazo a relação causal é da estrutura para o desempenho, passando pela conduta das empresas, existem importantes efeitos de realimentação entre essas categorias.

O esquema fundante da OI, presente nos textos de Koch (1980), Scherer \& Ross (1990), Carlton \& Perloff (1994), conforme adaptado, a partir destes autores e de Moraes (1996), é o seguinte (Figura 1): 
Figura 1 - Relações entre estrutura, conduta e desempenho

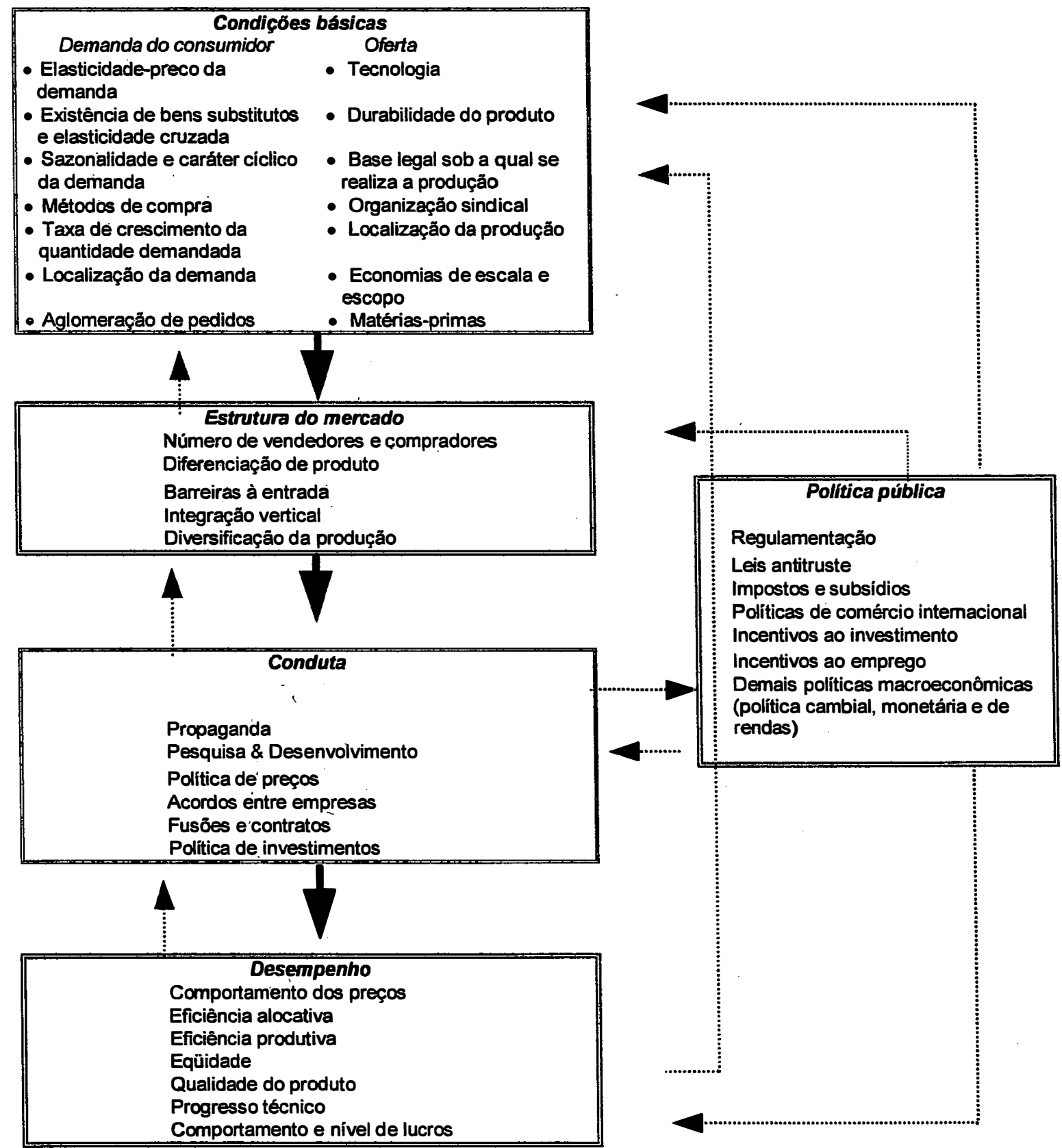

FONTE: Koch (1980), Scherer \& Ross (1990), Carlton \& Perloff (1994), Moraes (1996). 
Koch (1980, p. 4) afirma que é provável que a direção de causação no modelo tradicional seja, na verdade, uma via de duas mãos. Por exemplo, assume-se que em uma indústria ${ }^{3}$ onde existam barreiras à entrada, estas afetarão a conduta da empresa, por exemplo, sua política de preços. Ao mesmo tempo, no entanto, as táticas de estabelecimento de preços (pricing) podem, elas mesmas, resultar em barreiras à entrada. Da mesma forma, o comportamento dos preços pode influenciar as condições básicas de demanda, reduzindo o número potencial de bens substitutos disponíveis. Além disso, elementos da estrutura do mercado, tais como a diferenciação de produto, têm claramente o potencial de modificar condições básicas da demanda, como, por exemplo, a elasticidade-preço.

Neste sentido, conforme colocam Scherer \& Ross (1990, p. 6), as condições básicas e estrutura de mercado são endógenas, isto é, determinadas dentro do sistema de relações e não fixadas por forças externas a ele.

Por outro lado, de acordo com Porter (1991, p. 22), "a estrutura industrial tem uma forte influência na determinação das regras competitivas do jogo, assim como das estratégias potencialmente disponíveis para a empresa."

\section{A CONCORRÊNCIA NO MODELO ECD}

Do ponto de vista da empresa, a concorrência age no sentido de diminuir a taxa de retorno sobre o capital investido, pressionando no sentido de igualar a taxa de retorno à taxa básica competitiva ${ }^{4}$. Em outras palavras, quanto maior a concorrência, menores serão os lucros da empresa.

\footnotetext{
${ }^{3}$ As empresas (firmas) sāo freqüentemente agrupadas em setores. Todas as firmas de qualquer setor particular têm algumas funçōes comuns $\theta$, ao mesmo tempo, têm muitas diferenças, as quais geralmente sāo maiores que as semelhanças. Assim, os produtos ofertados por diferentes firmas do mesmo setor podem nāo ser substitutos próximos para os compradores $\theta$, por conseguinte, as firmas podem não competir diretamente umas com as outras. Por outro lado, denomina-se de indústria um subgrupo do setor no qual vendedores ou produtores ofertam bens e serviços que sāo considerados substitutos próximos para um grupo comum de compradores (Bain; 1968).

4 Segundo Porter (1991, p. 24), a taxa básica competitiva é "o retorno de 'mercado livre', é aproximadamente igual ao rendimento sobre títulos do governo a longo prazo ajustados para mais pelo risco de perda de capital."
} 
As forças competitivas que determinam a intensidade da concorrência na indústria e afetam sua rentabilidade são as seguintes (Porter, 1991):

I. a ameaça à entrada;

II. a ameaça de substituição;

III. o poder de negociação dos compradores;

IV. o poder de negociação dos fornecedores; 'e,

V. a rivalidade entre os atuais concorrentes:

Tais fatores dizem respeito não só à estrutura, mas também à conduta das empresas. É neste contexto que se desenham as estratégias das empresas frente às pressões ambientais e, por isso, torna-se necessário investigá-las.

A entrada de novas empresas na indústria pode causar queda nos preços ou aumento de custos para os players, na medida em que pode pressionar os custos das matérias-primas. No entanto, a entrada de um novo participante no mercado depende das barreiras à entrada que ele terá de superar.

Porter (1991) cita sete fontes principais de barreiras à entrada: economias de escala, diferenciação de produto, necessidades de capital, custos de mudança, acesso aos canais de distribuição, desvantagens de custo independentes de escala e aquelas estabelecidas pela política governamental. Destas, as fontes mais relevantes de barreiras à entrada na indústria de celulose são as seguịntes:

ECONOMIAS DE ESCALA: a presença de economias de escala atua como barreira na medida em que força a empresa a escolher entre duas opções indesejáveis: ingressar em larga escala, arriscando-se a sofrer uma vigorosa retaliação por parte das empresas existentes ou, alternativamente, ingressar no mercado em pequena escala, sujeitandose a uma desvantagem de custo. Por outro lado, caso existam economias de escala que ultrapassem os limites do mercado nacional, a empresa pode obter uma vantagem de custo produzindo de forma centralizada e vendendo no mercado mundial.

Além disso, há um outro tipo de barreira de entrada na forma de economias de escala quando existem vantagens econômicas na 
integração vertical. Nesta situação, a empresa que pretende entrar no mercado deve fazê-lo de forma integrada, principalmente se a maioria dos concorrentes estabelecidos já operam deste modo. Caso a empresa entrante considere operar de forma não-integrada, enfrentará uma situação difícil, pois não conseguirá preços competitivos para a aquisição de insumos. Os concorrentes integrados poderão oferecer 0 insumo no mercado em condições diferentes daquelas que são oferecidas às suas unidades interligadas ou, numa situação extrema, não irão considerar a venda deste no mercado. Por outro lado, as vantagens da integração vertical podem levar a empresa a competir na economia global, dado que a escala eficiente do sistema integrado verticalmente pode ultrapassar a capacidade de absorção pelos mercados nacionais.

NeCESSIDADES DE CAPITAL: naturalmente, a necessidade de investir grandes volumes de capital é uma barreira à entrada em determinada indústria. $O$ capital pode ser necessário não apenas para a instalação da planta industrial, mas também para suportar prejuízos iniciais de operação, despesas com publicidade inicial ou custos da constituição de estoques.

Ademais, mesmo que o capital esteja disponível nos mercados de capitais, a entrada em um determinado mercado representa sempre um risco, tal que os pretendentes à entrada deverão pagar um "prêmio de risco" pela utilização deste capital, o que representa uma vantagem para as empresas já estabelecidas.

DESVANTAGENS DE CUSTO INDEPENDENTES DE ESCALA: algumas vantagens de custos das empresas estabelecidas podem simplesmente ser impossíveis de serem igualadas pelas empresas entrantes, independentemente de seu tamanho e das economias de escala obtidas. As empresas já estabelecidas podem ter acesso privilegiado às fontes de matérias-primas, controlando-as. Podem ocupar localizações mais favoráveis, próximas às fontes de matérias-primas ou mercados consumidores. Podem também ser (ou terem sido) beneficiadas com 
subsídios oficiais, capazes de alavancar as empresas, proporcionando a elas vantagens competitivas duradouras. Este é o caso dos incentivos fiscais ao reflorestamento, concedidos entre 1966 e 1988, e que ajudaram as empresas do setor de celulose e papel na montagem de sua base florestal.

Política governamental: o governo tem o poder de dificultar, ou até mesmo impedir, a entrada em determinadas indústrias por intermédio de licenças de funcionamento ou limites ao acesso a matérias-primas. Pode ainda estabelecer padrōes para $\circ$ produto e para $\bigcirc$ processo de fabricação, tal que a necessidade de capital necessário à entrada aumente por conta da tecnologia requerida e/ou por conta da escala ótima das instalações necessárias ao cumprimento de tais exigências.

Quanto à ameaça de substituição, é importante notar que "os [produtos] substitutos reduzem os retornos potenciais de uma indústria, colocando um teto nos preços que as empresas podem fixar com lucro. Quanto mais atrativa a alternativa de preço-desempenho oferecida pelos produtos substitutos, mais firme será a pressão sobre os lucros da indústria" (Porter, 1991, p. 39).

No caso da indústria de celulose, o produto substituto próximo da fibra virgem é a fibra reciclada, que vem ganhando importância graças às pressōes ambientais.

O terceiro fator importante na análise da estrutura da indústria, segundo Porter, é o poder de negociação dos compradores.

"Os compradores competem com a indústria forçando os preços para baixo, barganhando por melhor qualidade ou mais serviços e jogando os concorrentes uns contra os outros - tudo à custa da rentabilidade da indústria. $O$ poder de cada grupo importante de compradores da indústria depende de certas características quanto à sua situação no mercado e da importância relativa de suas compras da indústria em comparação com seus negócios totais" (Porter, 1991, p. 40 - 41). 
Dentre todos os fatores importantes para este estudo e que motivam o comprador a negociar, com mais intensidade, o preço com o vendedor, são (Porter, 1991):

I. o comprador adquire grandes volumes em relação às vendas do vendedor;

II. os produtos que ele adquire representam uma fração significativa de seus próprios custos, tornando o comprador muito sensível em relação aos preços;

III. os produtos que ele compra são padronizados ou não diferenciados, de modo que o comprador possa pressionar as empresas, na certeza de sempre dispor de fornecedores alternativos;

IV. o comprador tem lucros baixos, criando-se, deste modo, grandes incentivos para a procura por redução de custos; $e$,

V. o comprador dispõe de informação total a respeito das condições de demanda, preços reais de mercado, custos dos fornecedores, etc.

Por outro lado, os fornecedores também podem exercer poder de negociação, particularmente quando o seu produto é um insumo importante para $\circ$ negócio do comprador. Não obstante, este poder pode ser diluído na medida em que o comprador pode ter acesso a produtos substitutos, ou a fornecedores alternativos para 0 mesmo produto.

Finalmente, o aspecto diretamente ligado à conduta das empresas é a intensidade da rivalidade entre os concorrentes. Esta é uma conseqüência da interação de vários fatores relacionados à estrutura da indústria. Dos apontados por Porter (1991), destacam-se:

Número de participantes: quando o número de participantes no mercado é grande, algumas empresas podem acreditar que seus movimentos não serão notados pelos demais players. De outro lado, quando a indústria é concentrada ou dominada por poucas empresas, os líderes ou a líder pode desempenhar um papel coordenador na indústria, dos quais a liderança-preço é um exemplo. 
DinÂMiCA de CRESCIMENTO NA INDÚSTRIA: o crescimento lento na indústria transforma o processo de concorrência na simples busca por uma fatia do mercado. Neste caso, a concorrência por uma parcela do mercado é mais intensa do que quando se observa um rápido crescimento na indústria.

AUSÊNCIA DE DIFERENCIAÇÃO: quando o produto é considerado um artigo de primeira necessidade a escolha do comprador é baseada em grande parte no preço do produto. Esta atitude pressiona os produtores a concorrer intensamente por meio de preços.

BARREIRAS DE SAídA ELEVADAS: tais barreiras mantêm as empresas competindo mesmo que elas estejam obtendo retornos baixos, ou mesmo negativos, sobre o capital investido. A existência dessas barreiras faz com que 0 excesso de capacidade na indústria não desapareça facilmente, afetando a rentabilidade de toda a indústria. Tais barreiras podem advir de ativos especializados, os quais apresentam valores baixos de liquidação ou altos custos de conversão. Interessante também é notar que, muitas vezes, as barreiras de entrada e de saída são freqüentemente relacionadas entre si. A obtenção de economias de escala, por exemplo, pode estar associada a ativos especializados, os quais dificultam a saída do mercado.

Capacidade aumentada em grandes incrementos: quando as economias de escala estabelecem a necessidade de um aumento de capacidade por meio de saltos, o equilíbrio entre a oferta e a demanda pode ser rompido. Os aumentos excessivos de oferta podem levar a indústria a enfrentar períodos de supercapacidade e de reduções de preço.

Quanto a este último fator, dois pontos importantes devem ser considerados. O primeiro diz respeito à expectativa da evolução da demanda futura. No caso da indústria de celulose, estima-se que o tempo médio para o start up de uma fábrica seja de, em média, três anos. Desta forma, as empresas muitas vezes tomam a 
decisão de aumentar a capacidade com base em expectativas do que ocorrerá num futuro razoavelmente distante. Em segundo lugar, há que se considerar a reação dos concorrentes. Se vários concorrentes adicionarem capacidade ao mesmo tempo, todos sofrerão com a supercapacidade na indústria.

\section{A QUESTĀO DO EXCESSO DE CAPACIDADE}

Frente a este último ponto, a questão estratégica para a empresa é como adicionar capacidade de modo a aumentar seu market share sem provocar um excesso de capacidade na indústria. Um método para se alcançar este objetivo é a estratégia preemptiva ${ }^{5}$. Segundo Porter (1991, p. 302),

"Conhecendo a demanda futura, as empresas irão competir entre si tendo como meta conseguir a capacidade suficiente para suprir a demanda e, uma vez que consigam, não será racional que outras acrescentem ainda mais capacidade, este jogo de preempção será geralmente acompanhado de intensa sinalização de mercado para tentar impedir que as outras empresas façam investimentos."

Quanto às razōes para o excesso de capacidade produtiva em uma indústria, Porter (1991) aponta, em primeiro lugar, o caráter cíclico da demanda, o qual pode provocar expectativas demasiado otimistas nas fases de crescimento em contraste com o excesso de capacidade nas fases de baixa procura.

Muitas vezes, a tecnologia de produção pode determinar a adição de capacidade em grandes lotes. Assim, o risco de grandes excessos de capacidade é considerável se várias empresas decidem investir ao mesmo tempo. Por outro lado, economias de escala significativas tornam maior a possibilidade de comportamento preemptivo, pois a empresa que adicionar capacidade em primeiro lugar terá uma

\footnotetext{
${ }^{5}$ De acordo com Porter (1991, p. 309), uma estratégia preemptiva é aquela "na qual a empresa procura apossarse de uma parte maior do mercado a fím de desencorajar os seus concorrentes quanto às suas intençōes de se expandirem e a fim de deter entradas. (...) A estratégia preemptiva é inerentemente arriscada porque envolve o comprometimento logo de início dos principais recursos com um mercado antes de os resultados deste mercado serem conhecidos. Além do mais, se não conseguir desencorajar a concorrência, isto pode conduzir a uma guerra desastrosa, uma vez que ocorre excesso de capacidade em ampla escala e as outras empresas que estão tentando
} 
vantagem de custo, pressionando todas a reagir de forma rápida e agressiva. Além disso, a decisão de aumento de capacidade logo de início pode proporcionar vantagens competitivas consideráveis, tais como menor tempo de entrega de pedidos e custo mais baixos de equipamentos e a oportunidade de capturar os desequilíbrios entre oferta e demanda.

Adicionalmente, quando os tempos de espera para aumento de capacidade são longos, as empresas baseiam suas decisōes em projeçōes de demanda e de comportamento num horizonte de tempo igualmente longo; pois a empresa pode ser penalizada por não ter aproveitado a oportunidade, caso a demanda prevista realmente se obsenve. Em outras palavras, o risco de ficar para trás, perdendo mercado, por falta de capacidade faz com que as empresas menos aversas ao risco fiquem mais propensas a investir.

No entanto, caso um grande número de empresas possua forças e recursos para adicionar capacidade significativa no mercado e as empresas individuais estejam tentando, preemptivamente, ganhar posiçōes, isto pode acarretar excesso de capacidade. Ademais, a existência de barreiras de saída significativas pode fazer com que o excesso de capacidade ineficiente não seja retirado do mercado com facilidade.

Em segundo lugar, ainda segundo Porter (1991), outra razão para o excesso de capacidade, é a ausência de diferenciação do produto da indústria, aliado à sua grande importância para os custos dos compradores. Nesta situação, estes últimos irão decidir pela compra olhando, fundamentalmente, para os preços. Desta forma, os vendedores são constantemente pressionados a operar com fábricas modernas e amplas para que possam ser competitivos. Se a escala eficiente mínima (EEM) estiver se elevando e as novas fábricas mais amplas que estiverem sendo construídas forem mais eficientes poderá ocorrer excesso de capacidade. No entanto, isto não ocorrerá caso a demanda esteja crescendo rapidamente ou o número de fábricas na indústria esteja diminuindo.

a preempção assumiram com o mercado grandes compromissos estrotégicos dos quais pode ser muito difícil recuar." 


\section{O PAPEL DAS POLÍTICAS PÚBLICAS}

Em uma perspectiva mais ampla, que transcende o horizonte da empresa isolada, é importante considerar o papel desempenhado pela política pública no que se refere ao desempenho econômico, pois os mercados podem falhar, fazendo com que o desempenho se torne inferior ao aceitável.

De acordo com Koch (1980, p. 436), as principais razões para a intervenção por intermédio de políticas públicas surgem:

I. quando existem estruturas de mercado indesejáveis;

II. quando se percebe uma necessidade de conservar um recurso natural que pode ou não ser de propriedade pública;

III. quando existem externalidades econômicas significativas associadas com a atividade das firmas em um mercado;

IV. quando a conduta de mercado das firmas causa indignação pública; e,

V. quando existe o desejo de diluir ou controlar o poder econômico de grandes empresas.

As possibilidades de intervenção são várias. O governo, como já mencionado, pode determinar quem pode e quem não pode operar em determinado mercado, delineando, assim, sua estrutura; pode também controlar o estabelecimento de preços e outras dimensões da conduta; pode afetar o comércio internacional, através de tarifas, cotas de importação e outros mecanismos, enfim, pode adotar uma série de medidas capazes de afetar tanto a estrutura de mercado quanto a conduta das empresas (Scherer \& Ross, 1990, p. 7).

Entretanto, a intervenção do governo pode ser vista de dois diferentes ângulos. Por um lado, pode-se considerar a hipótese do interesse público, a qual afirma que a atuação do governo beneficia de forma consistente os consumidores de bens e serviços. Por outro lado, pode-se considerar a hipótese da "captura", que sugere que os 
maiores beneficiários da regulação governamental são, na verdade, os produtores de bens e serviços.

\section{A AVALIAÇĀO DO DESEMPENHO}

De acordo com Bain (1968, p. 2), o desempenho das empresas se processa em três habilidades distintas:

I. como compradoras de trabalho e recursos naturais nos mercados de fatores de produção;

II. como unidades administrativas que organizam os meios de produção, materiais e trabalho, gerenciam seus usos, escolhem técnicas e métodos de produção, obtêm financiamento, assim por diante;

III. como vendedores e compradores nos mercados de bens e serviços que elas produzem ou usam. Nesta esfera, determinam a produção, preços, design do produto, preços de venda ao consumidor final, entre outras coisas. Numa palavra, fazem ajustamentos complexos, em vista das condiçōes de oferta e demanda, no mercado do produto em que atuam.

O conceito de "bom desempenho", no entanto, é multidimensional e, de acordo com Scherer \& Ross (1990, p. 4), engloba os seguintes objetivos:

I. eficiência nas decisōes econômicas que dizem respeito às questōes básicas da economia (o que, quanto e como produzir), de forma que os recursos escassos não sejam desperdiçados e, simultaneamente, que as demandas dos consumidores sejam satisfeitas;

II. eficiência na produção, de forma que os produtores façam uso das oportunidades abertas pela ciência e tecnologia para aumentar a produção por unidade de insumo e fornecer novos e superiores 
produtos aos consumidores, contribuindo para o crescimento da renda per capita no longo prazo;

III. uma operação por parte dos produtores que venha a facilitar o pleno emprego de recursos, especialmente os humanos ou, no mínimo, que não torne a manutenção do pleno emprego excessivamente difícil através de políticas macroeconômicas;

IV. uma distribuição de renda eqüitativa, implicando, no mínimo, que os produtores não obtenham recompensas em excesso em relação ao montante de serviços ofertados. Há aqui o desejo de alcançar a estabilidade de preços, pois a inflação distorce a distribuição de renda de vários modos.

\section{A APLICABILIDADE DA ECD AO TEMA DA DISSERTAÇĀO}

Especificamente no que concerne ao mercado mundial de celulose, podese observar que o paradigma da ECD é bastante adequado para a análise da indústria brasileira.

Em certos países, a política pública influencia, através da legislação ambiental, as condiçōes básicas do mercado. Do lado da demanda, os métodos de compra passam a se guiar por questōes como o processo de fabricação da celulose e a certificação das empresas. Do lado da oferta, a questão da obtenção de matéria-prima passa a ser importante, bem como a localização da produção.

Estas condiçōes básicas, por sua vez, influenciam a estrutura de mercado, impondo barreiras à entrada de competidores que não sejam ambientalmente corretos e possibilitando a diferenciação do produto de acordo com a obediência ou não a determinados padrōes ambientais.

A partir daí, a conduta também se modifica. Através da propaganda a indústria busca firmar uma imagem de "plantadora de florestas" em contraposição à de polvidora e destruidora do meio-ambiente e a política de investimentos, bem como a 
pesquisa e desenvolvimento direcionam-se a processos que não agridam $\circ$ meioambiente.

Por fim, graças a todas estas mudanças, o desempenho da indústria também se altera.

\subsection{Teorias sobre comércio internacional e suas ligações com a organização industrial}

Ainda dentro do paradigma ECD, algumas consideraçōes sobre as ligaçōes entre a organização internacional e a teoria do comércio podem ser úteis para analisar a indústria brasileira de celulose.

De acordo com Krugman (1992), a literatura que une a teoria do comércio à organização industrial é recente e divide-se em dois ramos de investigação principais. $O$ primeiro procura explicar o comércio internacional através das economias de escala e o segundo vê a competição imperfeita como o cerne do comércio internacional.

No modelo tradicional de comércio (Heckscher-Ohlin-Samuelson) as trocas deveriam acontecer entre países com diferentes dotaçōes de fatores e cada país exportaria bens intensivos no recurso que dispusesse em maior quantidade. Desse modo, o comércio se efetivaria entre países "complementares": países com abundância de capital versus países com abundância de trabalho, de forma que a composição do comércio seria o reflexo das vantagens comparativas de cada país.

Não obstante, nos anos 60 observou-se que o comércio que mais cresceu foi aquele entre países industrializados, muito semelhantes na sua dotação de fatores, além do que o comércio entre os países industrializados foi grandemente composto de trocas entre bens muito semelhantes (comércio intra-indústria). Isto levou os pesquisadores a argumentar que o comércio entre países industriais não era devido às vantagens comparativas, mas aos ganhos de escala, os quais explicavam o fato de que países com dotaçōes de fatores similares trocavam produtos similares. A partir daí, modelos de competição monopolística passaram a ser desenvolvidos de forma a tornar explícita a ligação entre a teoria do comércio e a organização industrial. 
O segundo ramo de investigação da teoria do comércio vê a competição imperfeita como o cerne do comércio internacional e preocupa-se, basicamente, com a relação entre a política de comércio do país e o poder de mercado das firmas domésticas; com o papel da discriminação de preços e dumping nos mercados internacionais; com a possibilidade de que a ação governamental possa desempenhar um papel estratégico proporcionando vantagens para as firmas domésticas na competição oligopolista internacional; e, finalmente, com possíveis novos argumentos a favor do protecionismo derivados da teoria da organização industrial.

Por outro lado, alguns trabalhos na linha organização industrial/teoria do comércio também demonstram que quanto maior o tamanho da firma, maior a probabilidade de que ela seja exportadora, dada sua capacidade de produzir 0 alto volume requerido pelos contratos de exportação e de arcar com os altos custos fixos do processo de exportação - os quais envolvem a obtenção de informações e o desenvolvimento de canais de exportação (Porcile, 1989).

Além disso, o volume exigido para a exportação se constitui numa dificuldade estratégica para as firmas menores que conseguem ter acesso ao mercado externo, pois elas acabam por exportar uma parcela maior de sua produção, em relação às firmas maiores, para determinados mercados. Tal fato as impede de diluir os impactos de flutuações econômicas localizadas sobre a demanda de seu produto.

Outros autores levam também em consideração outros fatores que podem influenciar o comércio internacional e que estão ligados à teoria da organização industrial, tais como a renda per capita, a distribuição de renda entre os países (dado que ela explica a estrutura da demanda), o tamanho relativo e absoluto dos países (importante na determinação das possíveis economias de escala) e também os "fatores gravitacionais", tais como existência de uma fronteira comum, importância das tarifas e barreiras comerciais e importância dos vínculos culturais (Porcile, 1989).

Especificamente no caso da indústria de celulose, a questão do tamanho da firma versus exportação possui também um outro aspecto relevante: é justamente o alto volume de produção o fator que torna possível à firma atingir ganhos de escala capazes de torná-la competitiva externamente. Os ganhos de escala são muito 
importantes para a indústria de celulose como um todo, uma vez que a competição internacional se dá, basicamente, por meio das vantagens competitivas oriundas de custos menores. A escala ideal que proporciona condiçōes de se atingir um preço internacional competitivo é considerável, tal que a luta pelos mercados é bastante intensa.

Frente a isto, as firmas também buscam mercados com um tamanho compatível com esta necessidade de escala, procurando também diversificar seus consumidores no sentido de diminuir sua exposição a um mercado específico.

Os "fatores gravitacionais" também são relevantes, na medida que os custos de transporte são parte importante do preço final do produto e a proximidade física, tanto das fontes de matéria-prima, quanto dos mercados consumidores é uma vantagem competitiva importante no comércio.

Ademais, a influência das barreiras ao comércio está intimamente ligada ao papel estratégico do governo. A política governamental poderia cumprir o papel estratégico de criar vantagens competitivas para as empresas de um determinado país ou eliminar as vantagens de outro no comércio internacional. Desta forma, a política governamental poderia barrar a entrada - ou dificultar a permanência - de determinadas empresas no mercado. Neste sentido, há o temor dos produtores nacionais de celulose de que os critérios de certificação acabem por proteger os produtores domésticos em cada um dos mercados importadores.

Não obstante, deve-se levar em conta a possibilidade de reação por parte dos outros governos. De uma perspectiva da teoria dos jogos, se ambos os países adotarem políticas protecionistas de comércio é bem possível que eles caiam na armadilha do dilema dos prisioneiros, ficando em uma posição pior do que estavam no início. 


\subsection{O conceito de competitividade}

Outros fatores importantes para a análise da indústria brasileira de celulose no mercado mundial são também revelados a partir de uma análise do conceito de competitividade.

A noção tradicional - e mais simples - de competitividade concentra-se no conceito de competitividade-preço e avalia a competitividade baseando-se na diferença entre a evolução de preços de exportação relativos entre $\circ$ país e seus concorrentes e a evolução do market share do país no mercado mundial do produto.

Este conceito é, basicamente, uma avaliação ex post, pois mede a competitividade através do desempenho das exportaçōes, isto é, são competitivas as indústrias que ampliam seu market share. É ainda o conceito mais amplo de competitividade, na medida em que abrange não só as condiçōes de produção, mas todos os fatores que inibem ou ampliam as exportaçōes de produtos e/ou países determinados, tais como as políticas cambial e comercial, eficiência dos canais de comercialização, dos sistemas de financiamento, acordos internacionais, estratégias de firmas transnacionais, etc. (Haguenauer, 1989, p. 1).

Este conceito, no entanto, é passível de algumas críticas. Primeiramente, há o caráter tautológico da definição: Kupfer, citado por Leiva (1994, p. 27), afirma que "se é competitiva a firma que domina ou cresce no mercado, é igualmente correto que irá dominar ou crescer no mercado justamente a firma que é competitiva."

Em segundo lugar, tal conceito não explicita os fatores responsáveis pela competitividade, é influenciado por variáveis externas à economia em questão e, por ser uma avaliação ex post, não torna possível o estabelecimento de relaçōes causais entre competitividade e outras varióveis também ex post, tais como market share, lucratividade ou taxa de crescimento. Além disso, alguns autores assumem que 0 desempenho é uma provável consequeência da competitividade e não sua expressão (Leiva, 1994, p. 27). 
A associação da competitividade com o comportamento dos preços apresenta, também, outros problemas, tais como a instabilidade do sistema financeiro internacional, que torna as taxas de câmbio irreais e dificulta a avaliação da paridade real entre diferentes moedas; e o fato de que parcelas crescentes do comércio internacional são realizadas por firmas transnacionais, de forma que os preços praticados constituem-se, na verdade, preços de transferência, que podem ser sub ou superfaturados e, assim, não guardam nenhuma relação com os preços praticados em mercados locais (Haguenauer, 1989).

Por outro lado, na medida em que as opções para aumentar a competitividade, dentro dessa abordagem, se reduzem, basicamente, à redução de salários e desvalorização do câmbio, surgem críticas quanto à utilização do dumping social.

Estabelece-se, por conta disto, uma diferença entre a competitividade "espúria" e a competitividade "autêntica". A primeira manifesta-se de três formas principais (Schwarzer, 1994, p. 41):

I. a competitividade é obtida às expensas da remuneração da mão-deobra, prejudicando a eqüidade social;

II. a competitividade é obtida pela exploração extensiva e predatória do meio ambiente e dos recursos naturais abundantemente disponiveis;

III. a competitividade é obtida pela baixa tributação direta de longo prazo da atividade exportadora, de forma a substituir aquela oriunda do progresso tecnológico.

A competitividade "autêntica", por sua vez, está baseada na eficiência, tal que o conceito de "competitividade-eficiência" pode ser considerado um sinônimo. Este conceito, ao contrário da competitividade-preço, é uma avaliação ex ante das condiçōes de produção, refletindo, portanto, o potencial competitivo de um participante de determinado mercado.

Desta forma, o conceito de "competitividade-eficiência" vê a competitividade como conseqüência da escolha adequada das técnicas de produção, 
capazes de alcançar, ou superar, os níveis de eficiência observados em um mercado particular.

Segundo Schwarzer (1994, p. 39),

"considera-se que exista um best practice internacional, vigente no mercado de cada produto individual, quanto à utilização de recursos na sua produção e à qualidade apresentada. Este best practice define um padrão internacional que precisa ser alcançado ou suplantado por quem queira ser competitivo. Isto somente pode ser obtido mediante incorporação de progresso técnico, ou seja inovações que permitam às empresas manterem ou aumentarem sua participação de mercado, gerando uma contínua pressão inovativa sobre os competidores."

Para que um país ou uma indústria específica atinja este best practice, há a necessidade de que exista um ambiente de cooperação contínua entre os centros de pesquisa pura e aplicada e as empresas, além da disponibilidade de uma infraestrutura adequada de equipamentos e comunicaçōes (Coutinho, 1992).

Além disso, a atividade de pesquisa \& desenvolvimento deve estar voltada à construção de vantagens comparativas no comércio internacional e isto é possível quando a indústria é capaz de identificar, imitar e adaptar novas tecnologias, pois de acordo com Coutinho (1992, p. 81), "... a competitividade não advém simplesmente da 'dotação de fatores e recursos' e dos seus preços relativos, muito embora esta possa (e deva) valer-se dessas condições, mas resulta de estratégias empresariais deliberadas de investimento, baseadas na capacitação tecnológica endógena e sistêmica, para produzir com eficiência máxima e para introduzir novos processos e produtos."

A própria incorporação do progresso técnico, porém, exige um certo grau de capacitação tecnológica, tócita e específica por parte do receptor e, neste sentido, a tecnologia é ao mesmo tempo um insumo e um produto do exercício de capacidades tecnológicas (Canuto, 1993).

Finalmente, são fatores também importantes para o conceito de "competitividade-eficiência" os aumentos relativos de produtividade, os quais estão 
relacionados, basicamente, com incorporação do progresso técnico, obtenção de economias de escala e de escopo e à maior capacitação técnica da mão-de-obra.

Portanto, tendo em vista o exposto acima, este trabalho não irá analisar a competitividade da indústria brasileira de celulose apenas pela evolução de seu market share no mercado mundial. Diferentemente disto, privilegiará o conceito de "competitividade-eficiência" que, como se viu, considera competitiva a indústria capaz de atingir um determinado padrão internacional definido pelo mercado, contemplando aspectos como exploração não predatória dos recursos naturais, progresso tecnológico e capacidade, senão de inovação, ao menos de imitação e adaptação às novas tecnologias.

\subsection{Metodologia}

Alguns dos trabalhos que utilizam o paradigma ECD estruturam-se de forma mais ou menos semelhante, caso de Moraes (1996), Santos (1996), Garcia (1997) e Marion Filho (1997). Caracteriza-se a indústria ou o mercado em análise e, após definir a estrutura teórico-metodológica, são utilizados dados secundários e de pesquisa de campo para, por intermédio da análise tabular e gráfica, ilustrar os fenômenos avaliados.

No caso do presente trabalho, para avaliar como as pressões ambientais afetam a conduta e desempenho da indústria brasileira de celulose procurou-se, da mesma forma que os trabalhos anteriores, efetuar uma análise da organização industrial do setor exportador de celulose, utilizando-se, basicamente, de dados secundários analisados nas formas tabular e gráfica.

Além disso, foi realizada também uma pesquisa de campo, sob a forma de questionários (ver Anexo A) enviados aos exportadores de celulose, a saber, Aracruz, Cenibra, Bahia Sul, Jari Celulose, Votorantim e Riocell. Estas são as empresas que exportam celulose no Brasil e são, portanto, alvo de pressões ambientais externas. 
O envio de questionários, como indicam os estudos anteriormente citados, constituem-se numa prática convencional em pesquisas que utilizam $\circ$ paradigma ECD e vêm apresentando resultados satisfatórios.

Dos seis questionários enviados em março de 2000, $2 / 3$ foram respondidos ${ }^{6}$. Não obstante, as empresas que retornaram os formulários representam, em conjunto, 79,48\% da capacidade instalada da indústria exportadora de celulose ${ }^{7}$, de tal sorte que a análise das respostas pode ser estendida para o restante da indústria sem maiores problemas.

Além dos questionários, foram realizados contatos, pessoalmente ou por telefone, com técnicos de algumas empresas aqui analisadas. Essas conversas serviram para esclarecer ou levantar pontos não contemplados nos questionários. Nessas conversas pôde-se, inclusive, obter informações sobre as empresas que não responderam os questionários.

\footnotetext{
- Apesar dos vários contatos estabelecidos, a Bahia Sul e a Jari nāo responderam aos questionários.

${ }^{7}$ A saber, Aracruz (32,42\%), VCP (20,92\%), Cenibra (18,30\%) e Riocell $(7,84 \%)$.
} 


\section{ALTERAÇÕES NAS CONDIÇÕES DE DEMANDA E OFERTA MUNDIAL DE CELULOSE}

Este capítulo analisa as alterações que ocorreram, nas últimas décadas, nas condições de demanda e oferta mundial de celulose. Essas alterações explicam, em parte, a evolução e a estrutura da indústria brasileira de celulose.

Inicialmente, avalia-se o surgimento de mercados demandantes de produtos ambientalmente corretos (o mercado ambiental) e sua extensão para o caso da celulose. A seguir, avalia-se como o processo de produção de celulose pode ser alterado de modo a contemplar essas pressões ambientais.

\subsection{O surgimento do mercado ambiental}

De acordo com Micheli (2000), a globalizaçāo é uma nova etapa do desenvolvimento econômico e político das sociedades nacionais e locais e o "mercado ambiental" é um dos vetores mais importantes desta nova etapa. A característica essencial deste "mercado ambiental" é sua força para integrar as diferentes sociedades nacionais a um mesmo processo, guiado ou regulado pelos mesmos valores e com a participação de atores globais.

O surgimento deste mercado se deu em três etapas principais, conforme mostra o quadro 1 (Micheli, 2000). 


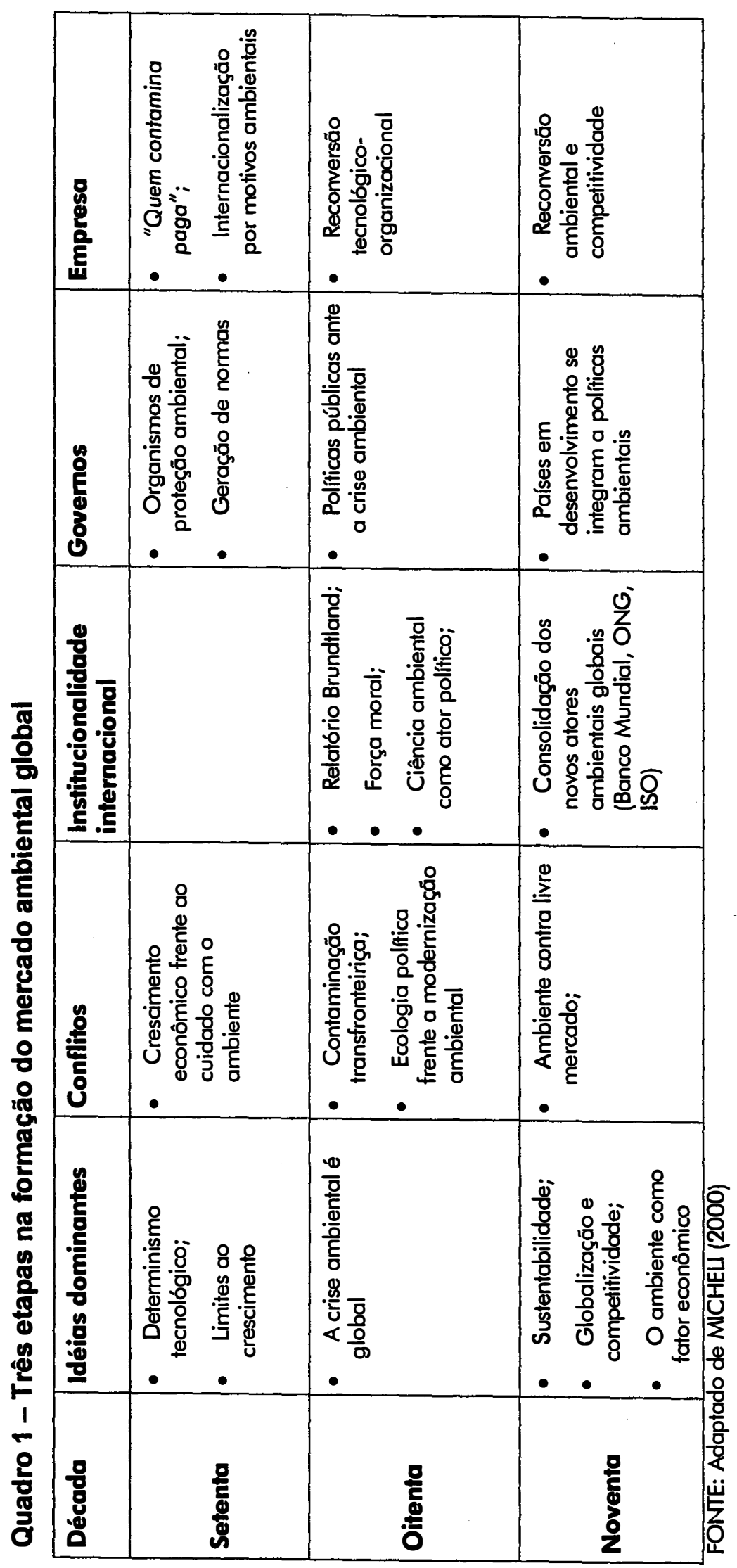


Os anos 70 marcam o início da mobilização de agentes econômicos e políticos a partir da crescente percepção de uma disfuncionalidade na relação economia-ambiente. Supunha-se, na época, que se poderia eliminar e remediar as "exceções ambientais" com os instrumentos tecnológicos e administrativos do processo de industrialização. O debate nestes anos estabelecia uma oposição de resultados entre crescimento econômico e cuidado ambiental. Qualquer mescla de ambos implicava um conflito: maior qualidade ambiental implicava num menor crescimento econômico e vice-versa e a única alternativa que se levantava frente a crise ambiental provinha da nascente aplicação do princípio "quem contamina paga", adotado como paradigma de política ambiental pela Conferência das Naçōes Unidas sobre ○ Meio Ambiente Humano (1972). Nesta década os países industrializados se dotaram de instrumentos com visão estratégica: os EUA criaram a Agência de Proteção Ambiental (EPA) como primeiro intento de uma política compreensiva frente à crise ambiental e, na Europa Ocidental, começavam a surgir as primeiras manifestações de uma política supranacional.

Nesta primeira fase da criação do mercado ambiental nas economias industrializadas, a ação empresarial adotou basicamente duas vias: a inversão em equipamentos para reduzir as emissões no final do processo (end of pipe) e a transferência das plantas contaminadoras dos países industrializados para as nações de menor desenvolvimento que não apresentavam restrições ambientais e tinham salários notoriamente inferiores. A atuação das empresas era reativa e ocupava um papel secundário na construção do mercado ambiental.

Nos anos 80, a crise ambiental se torna mundial e a tendência aberta na década passada, que propunha uma trajetória baseada em adaptações tecnológicas e na continuidade da expansão comercial e nos investimentos produtivos, enfrentou grandes questionamentos por parte de diversos atores políticos e sociais. Os anos 80 também foram os anos em que se desenvolveu a militância ecológica. Nascida nos EUA com organizações sociais como Os Amigos da Terra no final dos anos 60, a corrente crítica se implantou também na Europa, onde alcançou manifestações significativas com os partidos verdes. Em 1984 a ONU criou a Comissão para o Meio Ambiente e Desenvolvimento (Comissão Brundtland) que apresentou, em 1987, um relatório que 
propunha o desenvolvimento sustentável à comunidade internacional ${ }^{8}$. Em consonância com este Relatório, o Banco Mundial anunciou em 1987 que o ambiente e o princípio do desenvolvimento sustentável se constituíam em campos de financiamento fundamentais.

É importante salientar que, nesta mesma década, ganharam destaque temas como a perda da biodiversidade, o fenômeno do aquecimento global, a chuva ácida, a destruição da camada de ozônio, o problema da destinação do lixo tóxico, a contaminação radioativa e os acidentes com risco ambiental. Isto tudo culminou na visão atual de que os problemas ambientais possuem três elementos independentes: caráter global, intertemporariedade e dimensão extra-econômica (Corazza, 1996).

Segundo a autora,

"O caráter global dos problemas ambientais é devido ao fato de que as complexas inter-relações e sinergias ecossistêmicas fazem com que grande parte dos danos ambientais se difundam globalmente, dispersando seus efeitos para além des fronteiras administrativas e sócioeconômicas. Uma vez que $\circ$ [sic] problemas ambientais têm caráter cumulativo, seus efeitos podem ser irreversíveis e não completamente conhecidos. Cumulatividade, irreversibilidade e incerteza são elementos que tornam os problemas relevantes para as geraçōes futuras, daí sua propriedade intertemporal. Finalmente, a dimensão extra-econômica dos problemas ambientais pode ser compreendida pelo fato de que os danos provocados sobre o meio ambiente podem nâo ser completamente, e certamente não são, inscritos dentro do conjunto de preocupações normais da atividade econômica dos agentes (Corazza, 1996, p. 32-3)"

Finalmente, nos anos 90, o mercado ambiental já havia estabelecido suas regras e instituiçōes que assinalam os limites, os condicionamentos e as tendências da ação econômica e política ao redor da crise ambiental. Estas instituições são de dois tipos:

\footnotetext{
${ }^{8}$ O Relatório Brundtland ilustra a passagem do marco conceitual no qual o desenvolvimento e sustentabilidade ambiental eram vistos como metas conflitantes para a idéia de complementaridade entre as duas instâncias. 0 discurso sobre "moratória" do crescimento dá lugar à proposta de desenvolvimento sustentável, segundo a qual a satisfaçāo das necessidades das geraçōes presentes nāo deve prejudicar a possibilidade de que as futuras geraçôes satisfaçam as suas próprias necessidades (Corazza, 1996).
} 
A) as claramente integradas à economia política internacional: organismos financeiros, governos e ONG's que, em conjunto, constituem os pilares de um ordenamento internacional do mercado ambiental, de tal sorte que suas decisões e ações têm um caráter global e impõem limites a outros atores no mercado ambiental; $e$,

B) as normas e valores pertencentes ao âmbito da reconversão da empresa: a modernização ambiental que atua como força formal e informal indicando uma trajetória para a transformação tecnológica e organizacional da empresa.

O reflexo disto no comércio internacional é que hoje, embora a Organização Mundial do Comércio' (OMC) considere que cabe a cada país a prerrogativa de escolher o processo produtivo e o nível de degradação ambiental aceitável em seu território, a noção de que os problemas ambientais têm um caráter global, levou ao estabelecimento de acordos que tratam de processos e métodos de produção, tais como o Protocolo de Montreal, sobre substâncias prejudiciais à camada de ozônio, e a Convenção da Basiléia ${ }^{10}$, que prevê restrições à importação de países não signatários, contrariando a regra da OMC que não permite discriminações (Silva \& Bravo, 1994).

Não obstante, é importante lembrar que, no âmbito da Organização Mundial do Comércio (OMC), ao mesmo tempo que há o princípio fundamental da não-discriminação - expresso nas cláusulas da nação mais favorecida (artigo l) - existe, também, no seu artigo III, a regra do tratamento nacional, a qual estabelece que, após

\footnotetext{
${ }^{9}$ A OMC entrou em funcionamento em $1^{\circ}$ de janeiro de 1995, substituindo o Gatt. Este último foi assinado por 23 países, entre eles o Brasil, durante a Rodada Genebra, em 1947. O Acordo deveria ser provisório e vigir apenas até a criação da Organizaçāo Internacional do Comércio (OIT). No entanto, esta última terminou não sendo criada em razäo da recusa do Congresso norte-americano em ratificar o Acordo. Desta forma, o Gatt permaneceu, até 1995, apenas como um acordo multilateral de caráter provisório e sem base institucional. A OMC, ao contrário, é uma organização permanente, com personalidade jurídica própria e com o mesmo status do Banco Mundial e FMI, e que tem como missäo administror o sistema multilateral de comércio resultante da Rodada Uruguai. (Rêgo, 1996).

${ }^{10}$ A Convenção da Basiléia trata da importaçāo e exportação de resíduos tóxicos. Por intermédio dela, cada país se compromete a assegurar que a geração de resíduos tóxicos e outros resíduos seja reduzida a um mínimo, levando-se em consideração aspectos sociais, tecnológicos e econômicos. A Convençāo também tem como meta, dentre outras coisas, reduzir a um mínimo a movimentação transfronteira de resíduos, tóxicos ou não, e proíbe a sua exportação, particularmente para países em desenvolvimento (http//:www.unep.ch/basel).
} 
entrar em um mercado, o produto importado deve receber um tratamento eqüitativo em relação ao produto nacional, não podendo estar sujeito a impostos ou qualquer outra restrição que não seja também imposta, em igual teor, ao produto nacional (Rêgo, 1996).

Além disso, o artigo $X X$, que trata das exceções gerais, estabelece as circunstâncias que podem levar um país, ou países, a abandonar temporariamente seus compromissos multilaterais. Uma delas é a proteção da saúde e da vida das pessoas e dos animais ou a preservação dos vegetais. A questão polêmica, contudo, é se a proteção ao meio ambiente, contemplada no artigo $X X$, deve ou não estar restrita às fronteiras do país que impõe as restrições ambientais, ou se deve ou não considerar processos e métodos produtivos que tenham efeitos perversos sobre o meio ambiente em outro país (Castilho, 1994).

Por outro lado, uma outra forma de contornar o problema ambiental, e que vem se transformando na tendência predominante, é o estabelecimento de mecanismos "voluntários" de aceitação de determinados padrões.

De acordo com Silva \& Bravo (1994, p. 17),

"As políticas ambientais mais recentes dos países desenvolvidos têm enfatizado o papel da informação, visando influenciar as decisões de compra dos consumidores para estimular as empresas a atuarem de forma ambientalmente segura. [...] Utiliza-se o selo ecológico para informar ao público que em determinada categoria de produtos alguns são mais saudáveis ao meio ambiente que outros. Trata-se de um instrumento que permite às empresas demonstrarem a qualidade ambiental dos produtos e diferenciá-los no mercado, representando, portanto, uma vantagem competitiva. Para os consumidores, o selo é um instrumento que possibilita a redução do impacto ambiental através do consumo de produtos menos prejudiciais ao meio ambiente."

É importante notar, contudo, que o selo ecológico atesta muito mais que a simples "conformidade" de um produto. Um "certificado de conformidade" é dado a determinado produto que atende a requisitos mínimos estabelecidos por alguma norma e atestados por um laboratório credenciado, no que diz respeito unicamente ao uso do produto. A "certificação ambiental", por outro lado, tem caráter mais amplo e o "selo 
verde" pode ser visto com o grau mais alto de conformidade. Ele atesta que o produto e seu processo de fabricação não impactam - ou o fazem minimamente - o meio ambiente em relação a outros produtos similares disponíveis no mercado (Nahuz, 1995).

O Quadro 2 mostra os diversos "selos verdes" existentes, evidenciando a vanguarda alemã na questão ambiental.

\section{Quadro 2 - Programas de Rotulagem Ambiental}

\begin{tabular}{|lc|}
\hline PROGRAMA & DATA DE INÍCIO \\
\hline German Blue Angel & 1978 \\
Swedish Society for Nature Conservation & 1987 \\
Canadian Environmental Choice & 1989 \\
Japanese Ecomark & 1989 \\
Nordic White Swan & 1989 \\
Australia/New Zealand Green Spot & 1990 \\
US Green Seal & 1990 \\
Brand Paper (UK) Eco-Check & 1992 \\
Taiwan eco-label & 1992 \\
Norme Français Environnement & 1992 \\
Dutch Eco-Label & 1992 \\
EU Eco-Label & 1993 \\
Austrian Eco-Label & 1994 \\
\hline
\end{tabular}

Fonte: Webb (1994)

Todos os labels têm como característica serem obtidos por intermédio de um processo voluntário (não-mandatório), aplicado segundo critérios bastante específicos. Cabe, no entanto, uma qualificação quanto à questão de nãoobrigatoriedade de certificação, pois em vários países, principalmente os europeus, onde a legislação de meio ambiente é mais rigorosa, a certificação é condição sine qua non para a entrada de certos produtos no mercado.

Justamente por isto, o label da União Européia (UE) é o que tem recebido maior atenção. Embora cada um dos países membros possa continuar utilizando seu próprio selo ambiental de forma paralela ao da UE, a harmonização das legislações 
sobre meio ambiente deverá resultar em exigências ainda mais restritivas que as praticadas isoladamente pelos países da região, pois o Tratado de Maastricht eliminou a exigência de unanimidade em qualquer questão ambiental (Silva \& Bravo, 1994).

O Eco-label europeu é operacionalizado conforme a Figura 2.

Figura 2 - Procedimento de seleção de produtos e desenvolvimento de critérios para o Eco-label da União Européia

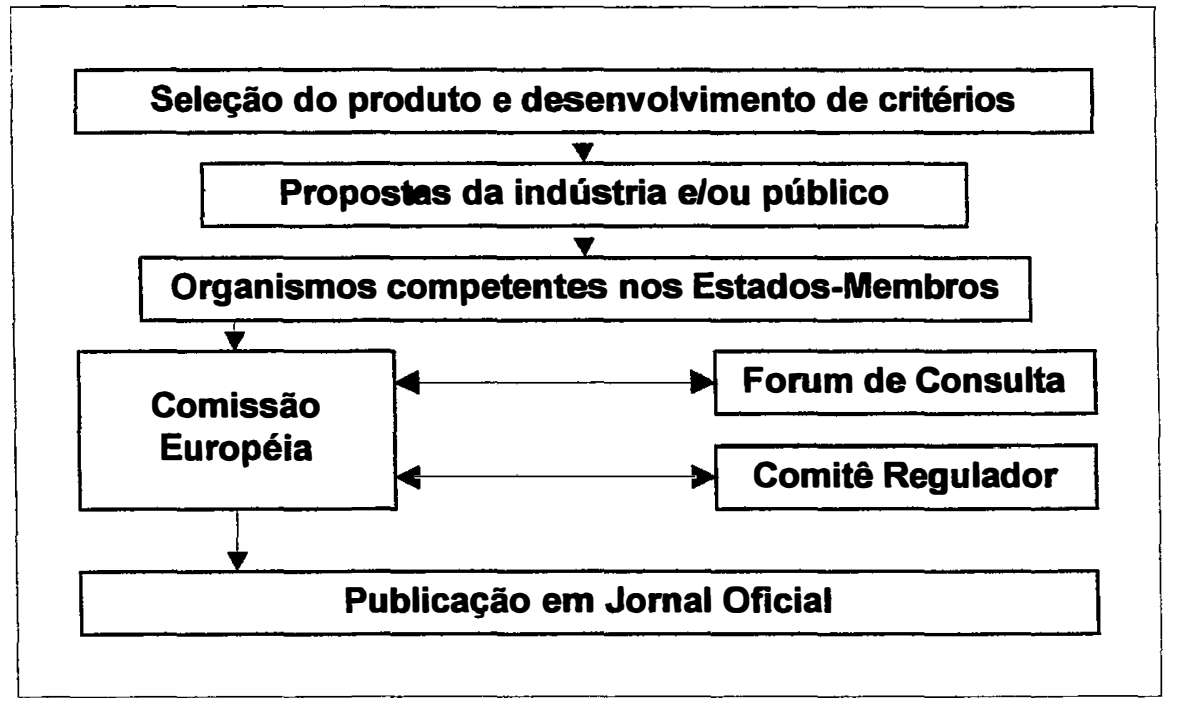

FONTE: Webb (1994)

É importante também notar que os critérios ecológicos são definidos com base no conceito "do berço ao túmulo". Desta forma, para que se verifique o impacto ambiental de um grupo de produtos, todo o processo produtivo é analisado, desde a extração da matéria-prima até a disposição do produto após o uso.

A decisão sobre se determinado produto deve ou não receber o Eco-label da UE é feito pelo organismo competente de cada país onde o produto é fabricado, ou através do qual o produto seja importado e, embora os critérios de atribuição sejam definidos por grupo de produtos, o selo é atribuído a produtos individuais e não a grupos de produtos, companhias ou organizações. 
Se determinado produto é aprovado, o interessado precisa assinar um contrato para o uso do Eco-label durante um período de tempo específico (três anos), no qual o solicitante deve pagar cerca de $0,15 \%$ das vendas anuais para ter direito de usar o Selo.

\subsection{O mercado ambiental para a celulose}

No âmbito do mercado mundial de celulose, como de resto, diante da forma com que problemas ambientais são caracterizados atualmente, a intervenção do governo, por intermédio de políticas públicas passou a ser justificada. Conforme visto no capítulo 3, algumas das razões para a intervenção são a necessidade de conservar um recurso natural que pode ou não ser de propriedade pública, a existência de externalidades econômicas significativas associadas com a atividade das firmas em um mercado ou quando a conduta de mercado das firmas causa indignação pública (Koch, 1980, p. 436).

Assim, nos países desenvolvidos, as modificaçōes no comportamento dos consumidores foram acompanhadas por uma legislação çada vez mais rígida em relação ao meio ambiente.

Desse modo, as pressões dos consumidores" acabaram por afetar toda a cadieia produtiva e a proteção ambiental acabou por adquirir uma nova dimensão, transformando-se num fator de competição estratégica entre empresas e até entre países (Roxo, 1999).

Ademais, deve-se levar em consideração que os grandes mercados mundiais de celulose concentram-se na União Européia. A região importou, em média, no período 1988 a 1998, algo em torno de $43 \%$ do total importado no mundo. Além disso, nesses países há maior preocupação, por parte dos consumidores, com as questōes ambientais.

\footnotetext{
"De acordo com Nahuz (1995, p. 15), "os movimentos ambientais reúnem hoje no mundo mais de 50 milhöes de afiliados. Como exemplo, apenas aqueles mais conhecidos, como o Greenpeace, o WWF - World Wide Fund for Nature e o FOE - Friends of the Earth, reúnem cerca de 11 milhöes de membros e movimentam entre si um orçamento de aproximadamente US\$ 400 milhōes."
} 
Como a legislação mais restritiva se aplicava também aos produtos importados, havia, por um lado, a preocupação dos exportadores de que estas leis se tornassem, na verdade, barreiras não-tarifárias e, por outro, a crença dos ambientalistas que a utilização de instrumentos de política comercial com fins ambientais seria um mecanismo poderoso de indução à adoção de políticas ambientalmente saudáveis em termos internacionais (Castilho, 1994).

Do ponto de vista dos exportadores de celulose, no entanto, levantavamse as seguintes questōes (Roxo, 1999):

i. como julgar a qualidade ambiental de um produto?

ii. que critérios utilizar?

iii. quem toma a decisão?

iv. como evitar distorções comerciais criadas por decisões tendenciosas?

Especificamente quanto à celulose, os critérios básicos utilizados para julgar sua qualidade ambiental dizem respeito à utilização sustentável das florestas, ao conteúdo de fibras recicladas, ao uso de cloro no branqueamento, aos padrões de emissões químicas e biológicas e à presença final de compostos orgânicos halogenados (AOX).

A este respeito, Fonseca (1995, p. 12) afirma que

"a grande - e nem sempre declarada - motivação ambientalista, especialmente dos governos de países europeus, é a escassez crescente de fonte de água no velho continente. É a partir deste fato que a pressão contra as empresas de papel e celulose, grandes consumidoras (e polvidoras) de água, aumenta consideravelmente acelerando o processo de busca de tecnologias livres de compostos e rejeitos tóxicos".

Frente a isto, o Eco-label encoraja embalagens "ecologicamente amigáveis" para todos os produtos comercializados dentro da UE, de sorte que, para receber o label, os produtores devem usar material reciclado e material reciclável nas embalagens.

A preferência dada à fibra reciclada pelo Eco-label deriva da premissa de que a utilização deste tipo de fibra é a melhor maneira de minimizar os impactos ambientais dos produtos de papel.

Segundo Castilho (1994, p. 71), 
"a tendência a um maior reaproveitamento dos materiais aparece como decorrência dos problemas de disposição do lixo, abrangendo tanto os bens utilizados, como os vasilhames e embalagens. A indústria de papel e celulose, assim, é duplamente afetada, tanto pelo lado dos produtos finais, que são muitas vezes utilizados como embalagem, quanto pelo lado da matéria prima, uma vez que as fibras virgens podem ser substituídas pelas recicladas. Existe, entretanto, um limite técnico em termos de qualidade do papel, para o uso de fibras recicladas - e sua reutilização exige crescentes porções de substâncias químicas."

Todas as categorias de papel (imprensa, imprimir \& escrever, embalagem e cartões) constituem-se em matérias-primas para reciclagem. Apenas os papéis sanitários, devido à contaminação a que são submetidos, e os papéis especiais, em função dos processamentos industriais a que são sujeitos, não podem ser reaproveitados (Macedo \& Valença, 1995).

Os objetivos de longo prazo da UE são alcançar cerca de $90 \%$ de recuperação (coleta) de papéis de embalagem, $60 \%$ de reciclagem de cada material de embalagem e o envio somente do resíduo do processo de coleta e seleção para aterros.

Desta forma, à medida que os organismos responsáveis pela certificação e os consumidores passam ver na reciclagem um processo ambientalmente sadio, a crescente demanda por fibras secundárias tende a reduzir o mercado para a fibra virgem.

A diferença entre a evolução da produção de fibras recicladas e a de celulose, mostrada no gráfico 1, ilustra este fato. 


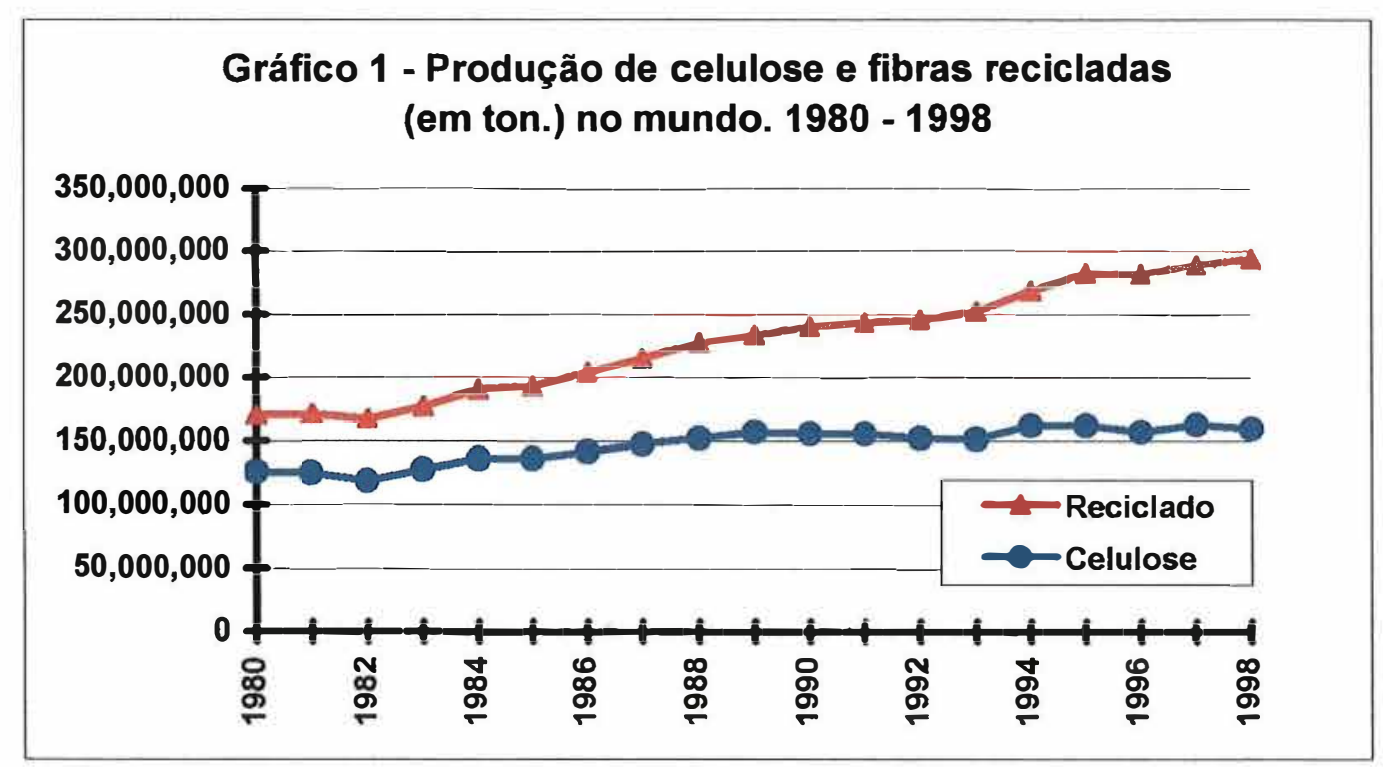

FONTE: hHp://www.fao.org

Nos principais mercados para a celulose brasileira, o impacto desta tendência de uma maior utilização da fibra secundária sobre o mercado de celulose de fibras virgens é significativo. A fim de avaliá-lo, pode-se fazer uso de dois critérios, que são os mais utilizados para medir os efeitos da reciclagem: a taxa de recuperação (TR) e a taxa de utilização (TU). A TR mede a relação entre a massa de papel coletado e a massa de papel consumido, considerando-se como tal o consumo aparente de papel. A TU, por sua vez, mede a relação entre a massa de aparas utilizada pelas empresas recicladoras e a massa de papel produzida ${ }^{12}$ (Macedo \& Valença, 1995).

Seguindo a tendência mundial, mostrada no gráfico 1 , todos os principais compradores da celulose brasileira vêm apresentando um consumo crescente de fibras recicladas. Mais que isso, conforme demonstra a Tabela 1, o consumo de papel reciclado vem crescendo a taxas maiores que o consumo de celulose.

\footnotetext{
${ }^{12}$ Normalmente, o critério da taxa de utilização tende a ser mais usado que o da taxa de recuperação, pois, de acordo com Macedo \& Valença (1995, p. 7), "alguns especialistas argumentam que boa parte do papel de imprimir e escrever consumido em todo o mundo se realiza sob a forma de livros e documentos, que tendem a ser retidos pelos consumidores por longo tempo, razão pela qual o simples cálculo da taxa de recuperação, [...] não conseguiria medir esse efeito de defasagem entre a data de consumo do papel e de sua possível reciclagem."
} 
Todos os países considerados apresentam uma sólida tendência de aumento nas taxas de utilização (TU) de fibras secundárias. Com exceção dos EUA e de Bélgica-Luxemburgo, todos os países apresentam, em 1998, taxas de utilização acima de $50 \%$, com destaque para a Coréia do Sul e Reino Unido, que chegam a mais de $70 \%$.

No caso de Bélgica-Luxemburgo, Reino Unido e Alemanha, ao contrário dos outros países, observa-se até mesmo uma queda no consumo aparente de celulose nos anos recentes. 


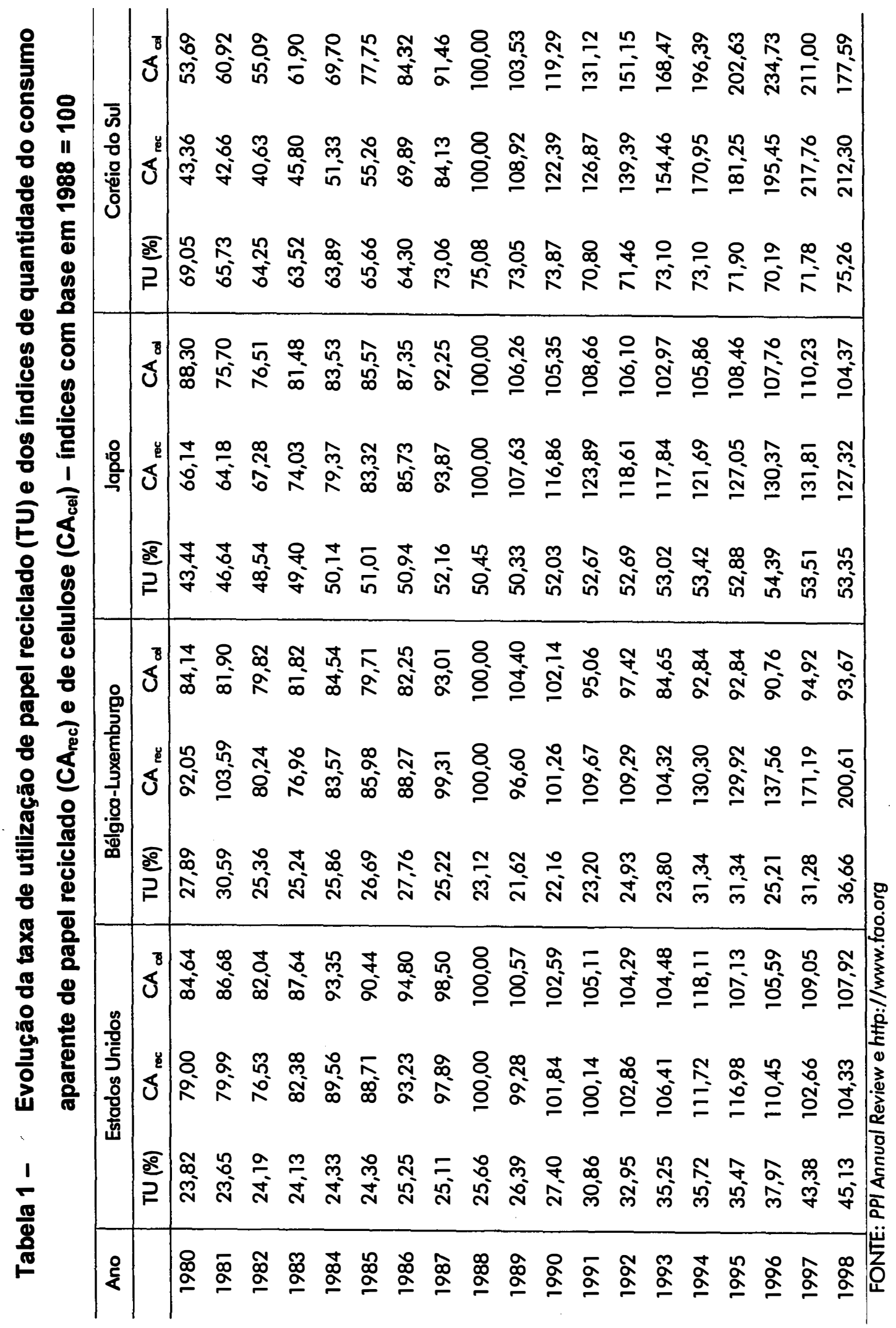




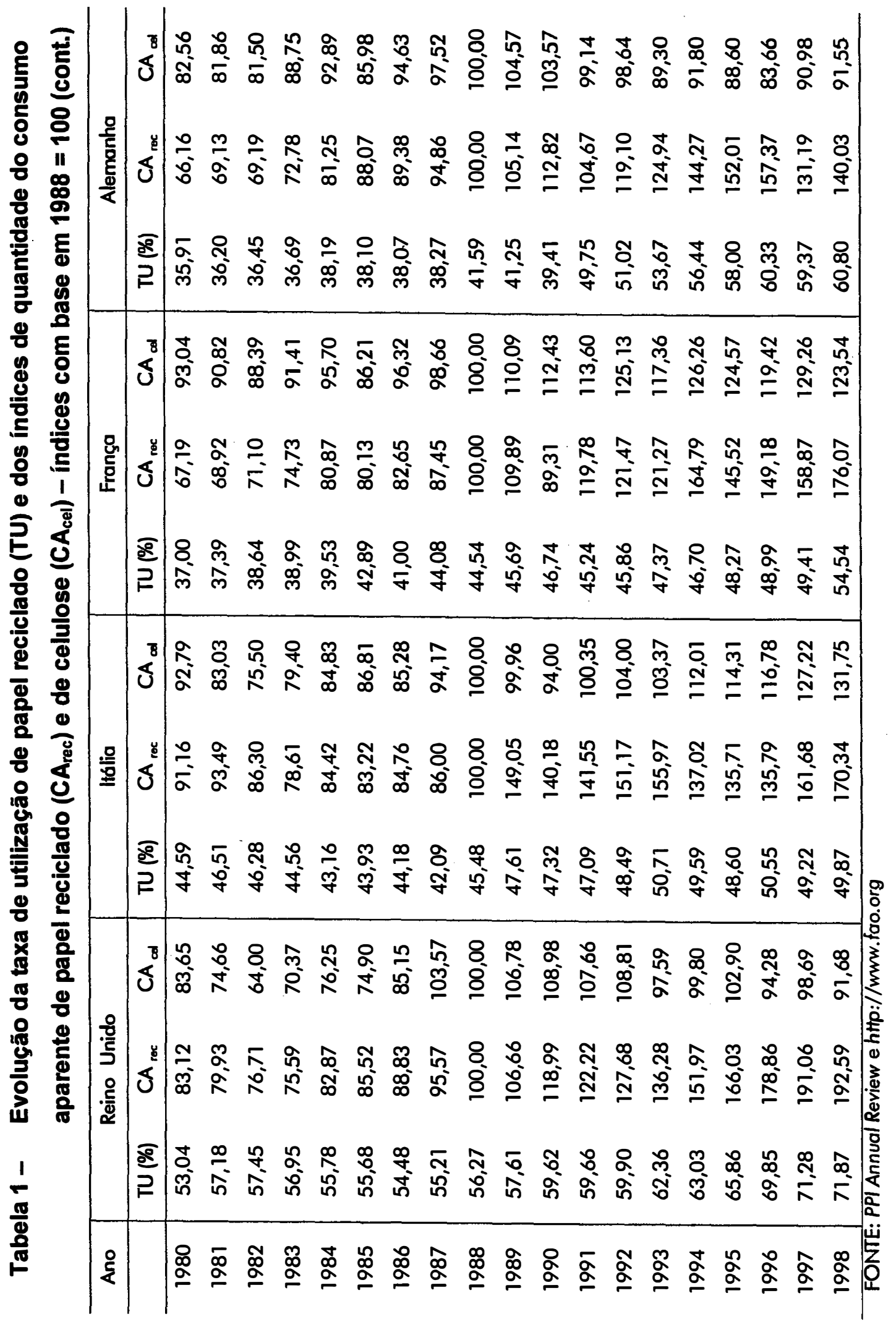


De igual modo, também é importante mencionar a dissociação existente entre o preço da celulose e a demanda por fibras recicladas, conforme mostra o gráfico 2. Nota-se que não há uma relação definida para essas duas variáveis, pois, caso houvesse apenas um processo de substituição causado pelas variações no preço da celulose, deveria ser esperado que o aumento do preço da celulose implicasse num aumento do consumo de fibras recicladas. No entanto, isto não se mantém ao longo de todo o período analisado neste gráfico. Nos subperíodos de 1980 a 1985, 1989 a 1993 e 1995 a 1998, há redução do preço da celulose e aumento no consumo de fibras recicladas.

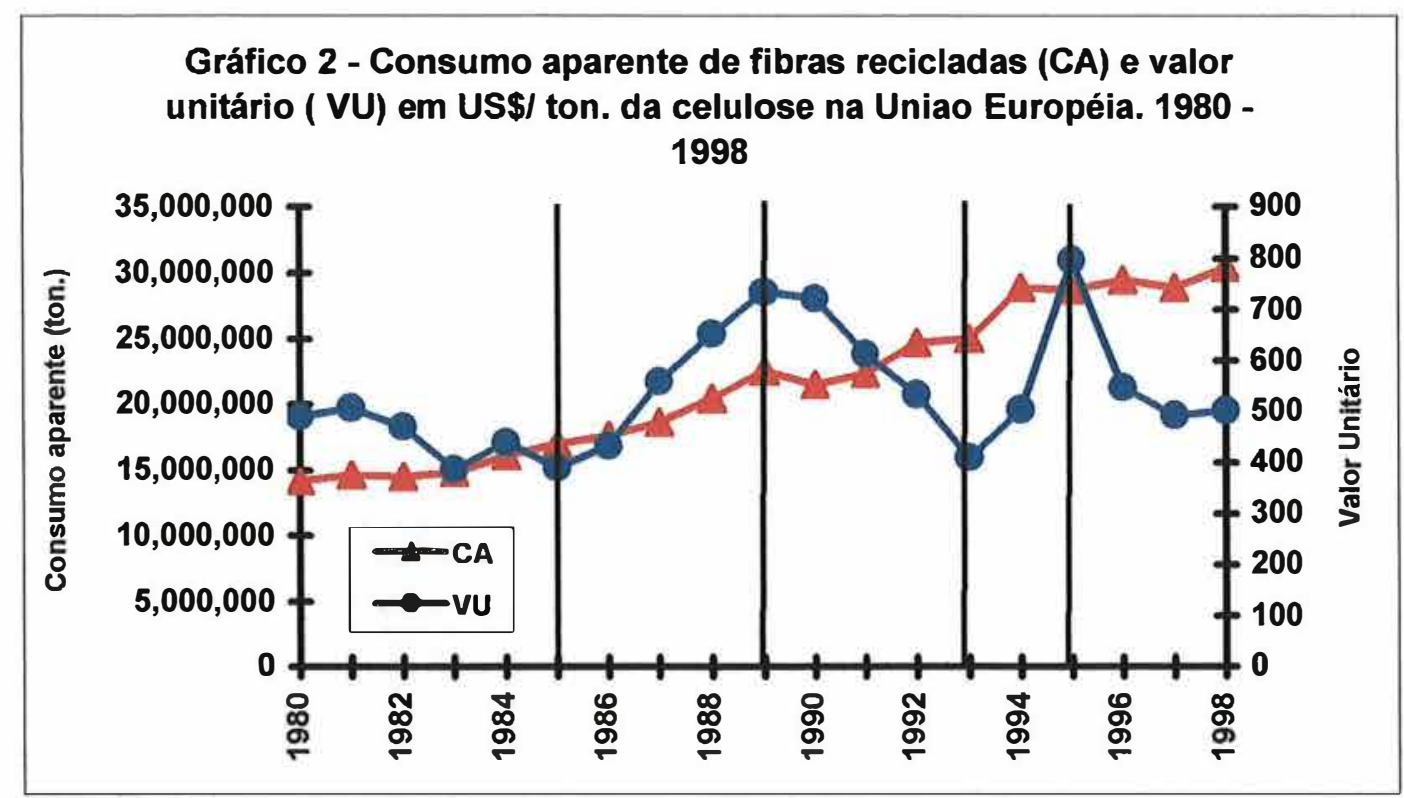

FONTE: $\quad h$ ttp://www.fao.org

NOTA: o valor unitário, em US $\$$ corrente, das importações da UE foi tomado como proxy do preço da celulose neste mercado.

Tal fato apenas reforça o que foi dito anteriormente, pois caso não houvesse uma tendência mais sólida de substituição da celulose por fibras recicladas, dever-se-ia observar um comportamento cíclico no consumo aparente de fibras secundárias que acompanharia o comportamento cíclico do preço da celulose. 


\subsection{As pressões ambientais incidentes sobre o processo de produção da celulose}

Para que se torne possível compreender a natureza e importância das pressões ambientais para a indústria de celulose e como ela pode adaptar-se a tais pressões, faz-se necessário descrever, ainda que de modo sumário, o processo de fabricação da celulose. Este processo envolve quatro etapas principais: etapa florestal, preparação da madeira, obtenção de celulose e secagem e acabamento, conforme mostra a Figura 3.

O tipo de celulose produzido é conseqüência da espécie de matériaprima vegetal utilizada. A celulose de fibra longa, mais resistente ao rasgo e à tração, é obtida a partir de espécies de madeira conhecidas como softwood, a celulose de fibra curta é obtida a partir de espécies de madeira dura, ou hardwood.

A celulose de fibra longa é constituída por fibras de comprimento médio superior a 2,5 mm. e a celulose de fibra curta por fibras de tamanho inferior a 2,5 mm.

O grande número de fibras por grama, característica da celulose feita a partir de espécies de madeira dura, contribui para um alto grau de opacidade do papel, bem como para seu volume e rigidez. Além disso, este tipo de celulose proporciona papéis com elevado grau de maciez e grande capacidade de absorção (ARACRUZ, 2000).

O processo de produção de celulose inicia com o recebimento das toras de madeira pela fábrica. Elas são primeiramente descascadas e levadas até picadores, para serem transformadas em cavacos que são, posteriormente, transportados até os digestores, onde se inicia o cozimento ou polpação.

A polpação objetiva amolecer a madeira, tornando possível o desfibramento e a deslignificação, que consiste em separar a lignina - responsável pela cor e resistência da madeira - das fibras de madeira. Estas fibras são, na realidade, a celulose industrial. 
Figura 3 - 0 processo de produção da celulose

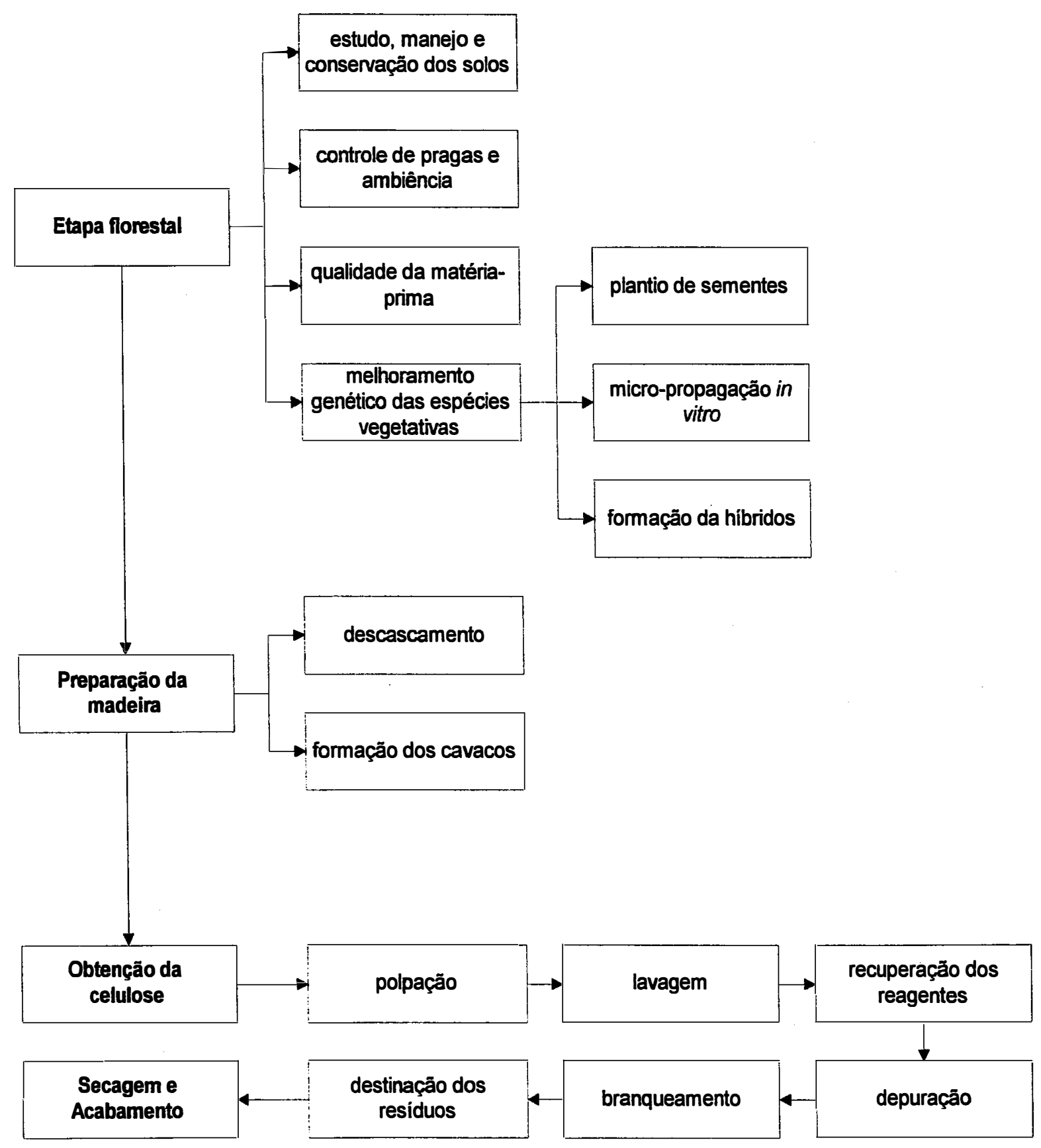


O processo de desfibramento (polpação) pode ser químico ou mecânico. No processo mecânico a trituração da madeira proporciona um rendimento bastante elevado, pois o aproveitamento chega a algo em torno de 90 a $95 \%$ da madeira. No entanto, a madeira triturada produz uma polpa com alto teor de lignina e a maciez e resistência do papel são afetadas. Por conta disso, a pasta mecânica é conhecida por apresentar alto rendimento e baixa performance (Corazza, 1996).

No processo químico, utiliza-se um digestor (vaso de pressão no qual os cavacos e o chamado "licor branco forte" são introduzidos continuamente pela parte superior) para a polpação. "O tempo total de cozimento da madeira é de 120 minutos, e realiza-se do topo até o centro do digestor. Do centro até a parte inferior, realiza-se uma operação de lavagem, a fim de se retirar a solução residual - o licor preto fraco (licor branco forte usado no cozimento mais lignina dissociada da madeira), que será utilizado como combustível na caldeira de recuperação" (ARACRUZ, 2000).

Este primeiro processo de lavagem objetiva retirar as impurezas solúveis da celulose. Em seguida, a celulose é retirada do digestor, sendo submetida a outro processo de lavagem nos difusores para ser, em seguida, depurada. $O$ processo de depuração consiste em submeter as fibras liberadas no cozimento (celulose industrial) a um processo de peneiramento com a finalidade de se retirar as impurezas sólidas (ARACRUZ, 2000).

O material residual da queima do licor preto fraco passa por uma série de reações químicas a fim de transformá-lo novamente em licor branco forte, empregado novamente no processo de cozimento dos cavacos de madeira.

Após o peneiramento, a celulose é submetida a um processo de branqueamento, que consiste em tratar a celulose com determinados reagentes químicos visando melhorar sua alvura, limpeza e pureza química. Quanto mais eficiente for o processo de deslignificação, menor será a necessidade de reagentes no branqueamento. Há assim, um trade off entre estas duas fases.

O branqueamento é o processo químico que separa a lignina das fibras e pode ser feito por dois métodos principais: método ácido ou sulfito e método alcalino ou kraft, que é o mais utilizado no Brasil. 
No caso do processo standard a seqüência utilizada para o branqueamento é iniciada com gás cloro (ou cloro elementar). A presença do cloro e de substâncias orgânicas, entre as quais a lignina, representa a maior parte no efluente de branqueamento e contribui para a formação dos compostos organoclorados, por intermédio da adsorção destas substâncias ao cloro. A grande dificuldade do processo standard é que a presença destes organoclorados, de cloretos e o baixo teor de sólidos no efluente o tornam impróprio para o envio ao ciclo de recuperação, tomando necessário, então, o tratamento dos efluentes líquidos no final do circuito produtivo (Corazza, 1996).

Após o branqueamento, a celulose é enviada para a secagem. $O$ objetivo é retirar a água da celulose até que ela atinja o ponto de equilíbrio com a umidade relativa do ambiente. Na parte final da máquina secadora fica a cortadeira, que reduz a folha contínua a um formato determinado (ARACRUZ, 2000).

As etapas deste processo mais sujeitas às pressões ambientais são a etapa florestal, o branqueamento e a destinação dos resíduos.

No caso brasileiro, a matéria-prima da celulose provém de florestas inteiramente plantadas. Já nos países escandinavos e no Canadá, ela é obtida de florestas nativas de propriedade estatal, o que torna os fabricantes destes países mais sujeitos à pressão de grupos ambientais contrários ao desmatamento, pois as espécies nativas são de crescimento lento.

Por outro lado, no caso das florestas plantadas, as pressões dirigem-se principalmente à perda da biodiversidade (tanto da flora quanto da fauna), causada pela monocultura, a exaustão do solo, a invasão de pragas e a contaminação dos recursos hídricos, causada pelos pesticidas (Corazza, 1996).

A etapa de polpação não apresenta problemas ao meio-ambiente, uma vez que os reagentes são recuperados e empregados novamente no ciclo produtivo. É a etapa de branqueamento da celulose que tem aparecido com mais freqüência nas discussões a respeito da preservação do meio ambiente. 
Neste particular, o branqueamento com cloro elementar tem sido alvo de pressões crescentes.

De acordo com Corazza (1996, p. 96),

"A campanha contra o uso do cloro no branqueamento da celulose começou em meados dos anos 80 quando traços de dioxina (organoclorado) foram descobertos em produtos como embalagens de leite, papel higiênico, filtros de café, toalhas de cozinha, fraldas descartáveis, etc. Na Suécia, a mídia e o grupo ambientalista Greenpeace responderam lançando ataque ao uso de cloro para o branqueamento da celulose. A campanha se difundiu amplamente, espalhando-se por toda a Europa."

No tocante ao tratamento de polventes e destinação dos resíduos os maiores problemas dizem respeito à polvição hídrica e atmosférica.

Segundo Higashi (1993, p. 12),

"O mais grave é o primeiro caso [rejeitos líquidos], porque uma infinidade de pedaços de fibras de madeira não aproveitados no processo produtivo são escoados nos rios. A decomposição desses rejeitos constituídos de fragmentos de fibras, lignina e hemicelulose, utilizam oxigênio da água, reduzindo a possibilidade de sobrevivência da fauna e flora aquática. [...] No caso da produção de pastas químicas, também é lançada, junto com os rejeitos líquidos, parte dos reagentes químicos utilizados no processo de polpação, branqueamento, [...] que não foram aproveitados. A polvição química é a mais prejudicial para a fauna e flora aquática e para os indivíduos que se servem dessas águas. O pior reagente químico é o cloro e os compostos organo-clorados que podem provocar o câncer."

Os parâmetros comumente utilizados para avaliar a carga de polventes no efluente são: (1) a Demanda Bioquímica de Oxigênio (DBO), que indica a quantidade de oxigênio necessária para a biodecomposição da matéria orgânica presente nas águas; (2) a Demanda Química por Oxigênio (DQO), que permite a mensuração rápida de material redutor, orgânico e inorgânico, presente no efluente; (3) o Total de Sólidos em Suspensão (TSS) que é o resíduo obtido na evaporação de uma determinada amostra do efluente a uma determinada temperatura; e, mais recentemente, (4) os Adsordable Organic Halides (AOX), que serve para designar a 
presença do cloro e de substâncias orgânicas responsáveis pela formação dos organoclorados, por intermédio da adsorção dessas substâncias ao cloro (Corazza, 1996).

No caso da polvição do ar, o problema são as emissōes particuladas, particularmente as de compostos reduzidos de enxofre, causadores do mal cheiro característico nas proximidades das fábricas. No entanto, a emissão destes gases, no nível atualmente observado, não é considerada nociva ao meio ambiente, constituindose num problema de bem-estar e não de saúde pública (Corazza, 1996).

Não obstante, convém salientar que a fibra reciclada, embora seja preferida pelos países europeus também apresenta problemas de tratamento de polventes e destinação dos resíduos. Os efluentes do processo de destintagem (deinking) são completamente diferentes dos efluentes da produção de papel e celulose. Eles requerem o controle de dejetos plásticos e uma configuração específica para $\circ$ tratamento de efluentes que leve em conta a natureza da DBO no ambiente. Além disso, o aumento da demanda por fibras recicladas significa, de outro lado, o aumento do uso de papel reciclado de baixa qualidade como matéria-prima, pois o limite de reciclagem varia de 5 a 10 vezes, dependendo do tipo de papel reciclado e de seu uso final.

Por outro lado, pode-se dizer que, dentre todas as preocupaçōes com o ambiente na fase industrial de produção da celulose, a principal é a questão da utilização de cloro elementar no branqueamento, devido ao problema da presença de dioxina no efluente.

Segundo Corazza (1996, p. 99),

"Não seria exagero dizer que o desenho das demandas ambientais em torno da questão da dioxina fez com que a redução e mesmo a eliminação completa do uso de cloro se tornasse uma das maiores preocupaçōes ambiental-mercadológicas da indústria de papel e celulose nos anos 90. Este fato fez com que o foco da mudança tecnológica no estágio de branqueamento fosse a redução de organoclorados, tanto na polpa celulósica quanto nos efluentes líquidos." 
Ainda segundo a autora, as alternativas disponíveis para a redução de organoclorados consistem em (1) trazer menos lignina para a etapa de branqueamento, (2) substituir o cloro na fase de branqueamento, e (3) destruir as substâncias cloradas tão logo elas sejam formadas. As duas primeiras opções consistem no emprego de tecnologias conhecidas como processo-integradas e a última em tecnologia de final de circuito (end-of-pipe). As opções para a substituição do uso de cloro elementar, por sua vez, envolvem duas possibilidades: (1) pré-branqueamento com oxigênio, e (2) substituição do cloro elementar por dióxido de cloro (Corazza, 1996, p. 100).

O pré-branqueamento com oxigênio permite a remoção de cerca de $50 \%$ da lignina, possibilitando uma grande redução da carga de efluentes. A outra possibilidade é a utilização de dióxido de cloro, em substituição ao gás cloro, na primeira etapa do branqueamento da celulose dando origem ao processo conhecido como ECF (Elemental Chlorine Free). Há ainda outra possibilidade tecnológica que é o branqueamento com peróxido de hidrogênio, originando o processo conhecido como TCF (Totally Chlorine Free).

Na segunda metade da década de 80 , a deslignificação por oxigênio e o branqueamento por dióxido de cloro tiveram um impacto significativo sobre a indústria na Europa em contraste com a situação na América do Norte. No início da década de 90 a principal discussão na Europa Ocidental era a eliminação do branqueamento com cloro. O novo foco era o branqueamento TCF, eliminando-se o dióxido de cloro. No entanto, em 1996, a produção TCF teve uma parada brusca. Em seguida ao pico no final de 1995, os preços da celulose despencaram e a situação do mercado na Europa não admitia mais os preços mais altos da celulose TCF, de forma que o prêmio em relação à celulose ECF foi caindo até não mais existir (Beal, 1997).

Desta forma, conforme demonstra a Tabela 2, a falta de disposição do mercado consumidor em pagar mais pela celulose TCF, de um lado, e as pressões ambientais, de outro, contribuíram para a consolidação do processo ECF como a tendência predominante na produção de celulose no mundo. Some-se a isto, a recente decisão da Agência de Proteção Ambiental (EPA) dos EUA que reconheceu a 
deslignificação com $100 \%$ de substituição do cloro por dióxido de cloro como a BAT (Best Technology Available) para as indústrias já existentes.

Tabela 2 - Evolução da produção de celulose (em milhões de ton.), segundo 0 processo de produção empregado. 1990 - 1998

\begin{tabular}{|c|c|c|c|c|c|c|c|c|c|c|c|c|c|c|c|}
\hline \multirow[t]{2}{*}{ Ano } & \multicolumn{3}{|c|}{ Escandinávia } & \multicolumn{3}{|c|}{ Estados Unidos } & \multicolumn{3}{|c|}{ Canadá } & \multicolumn{3}{|c|}{$\begin{array}{l}\text { Resto do } \\
\text { Mundo* }\end{array}$} & \multicolumn{3}{|c|}{ Mundo } \\
\hline & ECF & TCF & Outro & ECF & TCF & Outro & ECF & TCF & Outro & ECF & TCF & Outro & ECF & TCF & Outro \\
\hline 1990 & 2,3 & 0,1 & 6,5 & 0,5 & 0,0 & 26,8 & 0,7 & 0,0 & 10,3 & 0,0 & 0,0 & 19,2 & 3,5 & 0,1 & 62,7 \\
\hline 1991 & 4,0 & 0,3 & 4,7 & 1,6 & 0,01 & 25,6 & 1,3 & 0,0 & 9,7 & 1,4 & 0,1 & 18,2 & 8,2 & 0,4 & 58,2 \\
\hline 1992 & 6,6 & 0,6 & 2,0 & 2,8 & 0,01 & 24,4 & 2,6 & 0,04 & 8,4 & 2,9 & 0,6 & 17,0 & 15,0 & 1,2 & 51,8 \\
\hline 1993 & 7,7 & 1,3 & 1,1 & 4,0 & 0,2 & 23,0 & 3,9 & 0,05 & 7,0 & 4,4 & 1,1 & 15,7 & 20,0 & 2,6 & 46,8 \\
\hline 1994 & 8,5 & 2,2 & 0,0 & 6,0 & 0,2 & 21,0 & 5,5 & 0,05 & 5,5 & 5,8 & 1,6 & 14,3 & 25,8 & 4,1 & 40,8 \\
\hline 1995 & 8,3 & 2,8 & 0,0 & 9,1 & 0,3 & 17,9 & 7,3 & 0,04 & 4,2 & 6,4 & 1,6 & 14,7 & 31,2 & 4,7 & 36,8 \\
\hline 1996 & 7,6 & 2,6 & 0,0 & 10,4 & 0,2 & 16,6 & 8,1 & 0,04 & 4,0 & 7,9 & 1,7 & 14,4 & 34,0 & 4,5 & 35,0 \\
\hline 1997 & 8,3 & 3,1 & 0,0 & 13,3 & 0,2 & 13,8 & 8,7 & 0,04 & 3,4 & 7,7 & 1,8 & 17,2 & 38,0 & 5,1 & 34,4 \\
\hline 1998 & 7,9 & 2,9 & 0,0 & 15,5 & 0,2 & 11,5 & 9,1 & 0,01 & 2,8 & 9,7 & 1,7 & 17,2 & 42,2 & 4,8 & 31,5 \\
\hline
\end{tabular}

A Escandinávia, por sua vez, continua na vanguarda, no que diz respeito às tecnologias ambientalmente amigáveis e a região é a única que não utiliza mais o cloro elementar no branqueamento da celulose. Embora, como se verá adiante, algumas companhias de outras regiōes argumentem que os investimentos em celulose TCF trazem um custo injustificado e desnecessário, provocando uma queda na competitividade, é importante considerar que uma legislação mais rigorosa pode ser 0 incentivo para o desenvolvimento ou aplicação de soluções técnicas para a eliminação da polvição (Wyman, 1995).

Sob este ponto de vista, a indústria escandinava cria para si vantagens competitivas, pois a tecnologia é ao mesmo tempo um insumo e um produto do exercício de capacidades tecnológicas (Canuto, 1993).

Por outro lado, os ambientalistas ainda consideram o branqueamento ECF um processo agressivo ao meio-ambiente e o Greenpeace considera que apenas "metade do caminho" foi percorrido em direção a um método de produção ambientalmente adequado. 
O Greenpeace afirma que a indústria de papel e celulose é o segundo maior consumidor de cloro e a maior fonte de descargas tóxicas de organoclorados nas águas - cerca de 2 milhōes de ton./ano. Estas descargas seriam causadas pela utilização de gás cloro, dióxido de cloro ou hipoclorito de sódio. Além disso, as indústrias de celulose também lançam organoclorados no ar e diretamente na terra, por intermédio do lodo produzido nas fábricas.

O grupo argumenta que o branqueamento livre de cloro é o interesse de longo prazo da indústria e a eliminação do cloro significa mudar processos, não fechar fábricas ou eliminar empregos. A conversão requer um investimento de capital, mas uma fábrica poderia recuperar este custo em poucos anos através da redução de gastos em produtos químicos, energia, tratamento de água e disposição de lodo.

O Greenpeace ressalta ainda que a eliminação do cloro e seus subprodutos altamente corrosivos também permite que uma indústria opere com um "closed-loop system", economizando água e produtos químicos.

Finalmente, o Greenpeace argumenta que a utilização de dióxido de cloro ainda resulta na produção e lançamento de grandes quantidades de organoclorados, embora menos que quando se utiliza o cloro elementar. A redução seria de ordem de $80 \%$, mas, mesmo que todas as empresas produtoras de celulose do mundo convertessem para branqueamento com dióxido de cloro e fossem equipadas com aparelhos de controle do polvição no estado-da-arte, continuariam lançando, no mínimo, 140.000 ton./ano de organoclorados nas águas, além de lançamentos adicionais no ar, solo e nos produtos por ela fabricados.

De outro lado, a posição favorável ao processo ECF pode ser encontrada num documento, disponível no site da International Paper $^{13}$, e que contesta a visão dos ambientalistas, particularmente a do Greenpeace e dá uma idéia dos argumentos da indústria na escolha do processo ECF.

\footnotetext{
${ }^{13}$ http://www.internationalpaper.com/our_world/ecf_frame.html
} 
Para a International Paper, é impossível detectar dioxina tanto no processo ECF quanto no processo TCF, de sorte que o processo TCF não é o único método de branqueamento que protege o meio-ambiente. Segundo ela, não é possível detectar dioxinas no processo ECF, mesmo quando se utilizam aparelhos capazes de detectá-la em partes por quintilhão.

Além disso, as empresas de papel e celulose não são as maiores fontes de dioxina. Fontes como incineradores municipais e hospitalares, caminhōes a diesel, automóveis produzem muito mais dioxina que o conjunto de todas as empresas de papel e celulose nos EUA.

A adoção do processo TCF iria requerer o corte de mais árvores, uma vez que este processo requer de 5 a $11 \%$ a mais de fibras para produzir a mesma quantidade de polpa ECF. Ademais, o processo TCF aumentaria a polvição do ar e o uso de energia, pois ele gera $12 \%$ a mais de emissões de dióxido de carbono e aumenta em $10 \%$ o consumo de combustível fóssil.

Assim, como em termos ambientais, a celulose ECF seria igual à TCF, a conversão para branqueamento totalmente livre de cloro significaria um investimento desnecessário e a quantia envolvida faria com que as empresas menos eficientes fossem fechadas, custando muitos empregos.

Finalmente, de acordo com todas as consideraçōes feitas neste capítulo, nota-se, então, que as mudanças de atitudes dos consumidores em relação às práticas ambientais das empresas, o estabelecimento de esquemas de certificação, a tendência a uma maior utilização de fibras recicladas e a crescente restrição ao uso do cloro elementar no processo de branqueamento da celulose, acabam por estabelecer uma nova best practice no mercado internacional deste produto, definindo um novo padrão internacional de concorrência que, como visto no capítulo 3, atua de forma a pressionar todos os competidores no sentido de incorporar o progresso técnico, por intermédio de inovações - radicais ou incrementais - , sob o risco de não serem capazes de manter sua participação no mercado. No caso do Brasil, isto será evidenciado no capítulo 6 . 


\section{EVOLUÇÃO DA INDÚSTRIA BRASILEIRA DE CELULOSE E A INSERÇÃO DO BRASIL NO COMÉRCIO EXTERNO DESTE PRODUTO}

Este capítulo analisa como as alteraçōes no cenário internacional, consideradas no capítulo anterior, e as políticas governamentais afetaram a evolução da indústria brasileira de celulose, em especial o seu segmento exportador (item 5.1). Em seguida, avalia-se a participação do Brasil no comércio exterior de celulose (item 5.2). Esta participação está, por sua vez, intimamente associada com a evolução da indústria em estudo.

\subsection{Evolução da indústria brasileira de celulose}

Conforme já discutido no capítulo 3 do presente trabalho, a política pública pode cumprir um papel estratégico na criação de vantagens competitivas para as empresas. Ela pode criar barreiras à entrada de determinados players no mercado ou facilitar a permanência de outros por intermédio de financiamentos de longo prazo, restriçōes para as importaçōes ou planos de investimentos articulados com a iniciativa privada. Além disso, o governo pode influenciar no número de empresas existentes no mercado, estabelecendo condiçōes para que somente aquelas que obedeçam a certos requisitos sejam beneficiadas por determinadas políticas de incentivo.

Deste modo, o estudo da evolução da indústria brasileira de celulose tem como principal propósito demonstrar como a política pública, levada a cabo em boa parte pelo Banco Nacional de Desenvolvimento Econômico e Social (BNDES), contribuiu 
para criação e organização do setor exportador de celulose brasileiro, tal qual ele se apresenta hoje.

Em primeiro lugar, é importante notar que o capital e o empresariado da indústria de papel têm suas raízes nas atividades de importação e comércio de papéis realizados por imigrantes. As principais empresas iniciaram suas atividades a partir da comercialização de papel importado, passando por atividades gráficas até evoluírem para a fabricação de papel. Note-se que, entre 1885 e 1925, são instaladas no país a Fábrica de Papel Paulista Salto, a Companhia Melhoramentos e a Companhia Fabricadora de Papel (que deu origem ao grupo Klabin), a fábrica de papelão Simão e Companhia (que originou o grupo Simão, adquirido, posteriormente, pela VCP), a Indústria de Papelão Limeira S.A. (que originou o grupo Ripasa), entre outros. Nesta época, a pasta de madeira e a celulose eram quase que totalmente importadas e a atividade florestal era completamente desvinculada da indústria do papel (Soto, 1992).

De acordo com Paladino (1985, p. 257):

"A maior parte da matéria-prima utilizada nas fábricas de papel era importada. Os países da Escandinávia e a América do Norte já haviam estruturado sua produção de celulose e eram os grandes exportadores mundiais dessa matéria-prima. Outra parcela da matéria-prima era suprida pelos papéis velhos e aparas. $E$, finalmente, algumas pequenas fábricas produziam sua própria matéria-prima utilizando-se de diferentes tipos de vegetais regionais. "

Desde o seu nascimento até hoje, a indústria de papel e celulose sempre contou com o apoio fundamental do governo para seu desenvolvimento e conformação de sua estrutura.

No final da década de 20, a indústria é atingida pela crise de 1929, a qual teve efeitos devastadores sobre os preços do café. Uma vez que parte significativa da economia brasileira dependia do desempenho deste produto, vários setores foram afetados, como a indústria de papel.

Diante da crise de superprodução de café (nosso principal gerador de divisas naquela época) e das grandes dificuldades financeiras atravessadas por muitas 
empresas, o governo proibiu - até 1937 - a importação de máquinas para a instalação de novas fábricas de papel e criou um fundo especial para socorrer as empresas em dificuldades. O resultado deste processo foi a concentração de capacidade de produção nas maiores empresas existentes.

Por outro lado, as dificuldades no balanço de pagamentos e a elevaçāo do preço da celulose importada causada pela desvalorização da moeda nacional fizeram aparecer as condiçōes para o surgimento de um segmento nacional produtor de pastas no país. Note-se que "em 1933 ○ Estado concedeu isençāo de impostos de importação e taxas alfandegárias às máquinas, acessórios e todos os insumos necessários para as empresas organizadas com o fim de produzir celulose" (Suzigan citado por Soto, 1992).

Desta forma, as fábricas de papel obedeceram à lógica geral do modelo de substituição de importaçōes, sendo criadas para atender faixas de demanda que não podiam ser atendidas por importaçōes - caso dos papéis de qualidade inferior, destinados a embrulhos e embalagens simples - e para fabricar papéis que, embora passíveis de importação, pressionavam de modo negativo o saldo da balança comercial, tais como os papéis de imprimir e escrever. Somente num segundo momento, quando a produção nacional de papéis passou a demandar uma quantidade de celulose que justificava a instalação de fábricas é que começaram a surgir as primeiras unidades, próximas aos locais onde havia a matéria-prima (BNDES, 1991).

Em 1934, o grupo Klabin adquiriu do Banco do Estado do Paraná a fazenda Monte Alegre e iniciou a implantação de uma fábrica de papel imprensa que também produzia pasta mecânica e celulose semi-branqueada, dando origem ao processo de integração vertical na indústria. Inaugurada em 1946, ela era a maior fábrica de papel e celulose do país.

Para Mendonça Jorge (1992, p. 27), este empreendimento traça uma linha divisória no desenvolvimento da indústria de papel e celulose no país,

"Em primeiro lugar, porque trata-se do primeiro projeto significativo de uma fábrica de papel integrada (produção conjunta de celulose e papel) e, sobretudo, utilizando recursos florestais nacionais. Em segundo lugar, porque é o primeiro projeto onde aparece uma relação explícita entre o 
Estado e a iniciativa privada, através de uma política pública deliberada de apoio ao desenvolvimento do setor."

É importante frisar, porém, que o Brasil era um dos poucos países tropicais a possuir uma grande reserva nativa de uma espécie de conífera (a Araucaria augustifolia ou pinheiro do Paraná) muito semelhante às utilizadas nos países onde se desenvolveu a tecnologia da fabricação de celulose.

Conforme Paladino (1985, p. 258),

"A tecnologia mundial de produção da matéria-prima [para o papel] pastas químicas e a mecânica - era baseada, até meados do século XX, fundamentalmente nas espécies Coníferas, as resinosas dotadas de fibra longa. Portanto, além de dominar essa tecnologia, os países que desejassem produzir a matéria-prima teriam de possuir ou investir em terras, florestas e usinas processadoras de pasta. Além disso, deveriam ser capazes de competir ao nível dos preços com as pastas importadas."

No ano de 1950, o Brasil era praticamente auto-suficiente em produção de papel, exceto em papel imprensa. No entanto, importava mais de $70 \%$ da celulose de que necessitava.

Não obstante, no início da década de 50 começaram a surgir preocupações quanto à disponibilidade de matéria-prima para suprir a demanda mundial de celulose, pois as florestas de coníferas das regiões temperadas não seriam suficientes. Frente a isto, os países desenvolvidos voltaram-se com interesse para 0 aproveitamento de novas espécies florestais tropicais e temperadas, adaptando novas técnicas de produção e proporcionando ao Brasil a possibilidade de lançar-se como grande produtor de celulose (Paladino, 1985).

A produção brasileira de celulose de fibra curta passou de 1.590 toneladas em 1950 para 51.900 toneladas em 1956. Este aumento de produção baseou-se fundamentalmente no eucalipto. O governo de São Paulo possuía reservas que foram plantadas desde 0 início do século para alimentar as caldeiras das locomotivas e fornecer dormentes para vias férreas. Quando, no pós-guerra, as locomotivas passaram a usar óleo diesel e tração elétrica tais reservas foram 
aproveitadas. Assim, a importação de celulose, que era de cerca de $73,7 \%$ do consumo aparente em 1950 reduziu-se a 28,8\% em 1960 (Soto, 1992 e Paladino, 1985).

Em 1955, a Cia. Suzano iniciou, em fase experimental, a produção de celulose de fibra curta de eucalipto e em 1961 foi produzido no Brasil, pela primeira vez no mundo, o primeiro papel feito integralmente com celulose de fibra curta.

O primeiro programa governamental de investimentos específicos para o setor de celulose e papel surgiu na segunda metade da década de 50 , inserido no Plano de Metas. Tal plano fixava, dentre outras coisas, a auto-suficiência do país na produção de celulose, mas, em 1959 as metas iniciais foram revistas para menos ${ }^{14}$.

Neste período algumas empresas de capital estrangeiro entraram no setor, juntando-se à Rigesa, subsidiária da West Virginia, Pulp and Paper Company, fundada em 1953. Em 1958 foi constituída a Manville, subsidiária da Manville Corporation. Neste mesmo ano também apareceu a Champion Papel e Celulose Ltda., subsidiária da Champion Papers Incorporation, que iniciou suas atividades em 1960, produzindo exclusivamente celulose de fibra curta. Esta última foi a primeira a exportar papel fabricado integralmente com essa celulose (Soto, 1992).

Até meados da década de $60,0 \mathrm{BNDE}^{15}$ priorizava o setor de transportes, a expansão dos entrepostos de armazenagem e a geração de energia elétrica. Mesmo assim, em 1955 o Banco aprovou a concessão de financiamento à Celulose e Papel Fluminense S.A., seu primeiro passo em direção a um maior apoio ao setor. Entre 1955 e 1965 o financiamento ao setor era esporádico e ocasional (BNDES, 1991).

Em 1960, o país já produzia mais de $70 \%$ de seu consumo aparente de celulose, baseando-se fundamentalmente na produção de celulose de fibra curta. Nesse período, surgiram os primeiros excedentes exportáveis. No entanto, o país continuava deficitário na produção de celulose de fibra longa.

\footnotetext{
${ }_{14}$ De acordo com Paladino (1985, p. 280, rodapé), as metas foram revistas devido a: (1) atraso nos projetos de produção de papel jornal, (2) montante excessivo de investimentos para a exploraçáo das reservas florestais; (3) pressão demasiada sobre o Balanço de Pagamentos e (4) conveniências de comércio exterior.
} 
Em 1961, quatro empresas produziam exclusivamente celulose para o mercado: Champion, Cambará, Celulose Brasileira e Sacraft.

A partir da segunda metade da década de 60, o BNDE muda de atitude em relação ao setor de papel e celulose. Passa agora a adotar uma postura de fomento, graças a três fatores fundamentais (BNDES, 1991):

1. a tarefa original do Banco era a de reorganizar e aparelhar a infraestrutura do país e isto foi feito de 1952 a 1964. Numa etapa posterior o Banco passou a fomentar indústrias;

2. a partir de pesquisas realizadas no final da década de 50, o Brasil conseguiu produzir, a partir do eucalipto, celulose de fibra curta de boa qualidade para a produção de papel de imprimir e escrever, proporcionando o surgimento de condições para o país competir no mercado internacional; e,

3. a realização de um estudo, contratado pela Associação Nacional dos Fabricantes de Papel e Celulose (ANFPC) e financiado pelo BNDE, que analisou profundamente as empresas do setor de papel e celulose no Brasil, fornecendo aos analistas do Banco informaçōes confiáveis sobre o setor.

Este estudo teve uma grande influência na política de financiamento do BNDE e, por conseguinte, no desenvolvimento do setor. $O$ trabalho alertou o Banco para a necessidade de estabelecer critérios operacionais relativos ao dimensionamento das novas fábricas e ampliação das já existentes a serem apoiadas pelo BNDE. Apontava para a necessidade de se realizar novos investimentos direcionados à implantação de fábricas de celulose capazes de atingir escalas de produção capazes de gerar excedentes para exportação. O suprimento interno insatisfatório de celulose, aliado às dificuldades de produção de celulose de boa qualidade em locais distantes

15 O BNDE foi criado em 1952 e " $\mathrm{S}$ " foi adicionado à sigla somente em 1982 quando o governo instituiu o Finsocial e repassou recursos desse fundo para o Banco, com a finalidade de financiar projetos sociais (BNDES, 1991). 
dos maciços florestais fez com que surgissem muitas unidades de pequeno e médio porte produzindo celulose de qualidade inferior (BNDES, 1991).

Em 1966, surgiu a primeira empresa de grande porte para a produção de celulose de mercado para exportação. Trata-se da Borregaard S.A., subsidiária de uma firma norveguesa, e que foi implantada com uma capacidade de 500 ton./dia de celulose de fibra curta.

Em 1967, por meio da Resolução 276, o Conselho de Administração do BNDE decide conceder prioridade aos projetos de implantação ou ampliação de capacidade para produção de celulose e papel.

Além disso, na segunda metade da década de 60 o setor de papel e celulose é grandemente influenciado por duas medidas de política governamental: o Decreto Lei 5.106/66 e a Decisão 196/68 do BNDE.

Em meados da década de 60, foi promulgado o Decreto-Lei 5.106/66 para viabilizar a implantação de maciços florestais pelas empresas e, assim, cumprir as determinações do Código Florestal, promulgado em 1965.

Este decreto-lei regulamentou os incentivos fiscais, previstos no Código Florestal de 1965, destinados a gerar recursos para investimentos em reflorestamentos. Assim, o referido decreto-lei permitiu às pessoas físicas abaterem da renda bruta as importâncias efetivamente aplicadas nesta atividade no ano-base da tributação e às pessoas jurídicas abater até $50 \%$ do Imposto de Renda devido (Bacha, 1991).

Os resultados da regulamentação dos incentivos fiscais foi uma grande expansão da área reflorestada nos anos seguintes, como se observa na tabela 3.

A Decisão 196/68 do BNDE, por sua vez, estabeleceu que, a partir de então, os incentivos financeiros do Banco seriam direcionados para projetos que obedecessem a determinadas escalas mínimas de produção que, no caso da celulose, era de cerca de 100 ton./dia. Adicionalmente, o Banco passou a exigir que as empresas demonstrassem a capacidade de suprir a si próprias com, no mínimo, 50\% das suas necessidades de madeira.

Segundo um documento do próprio Banco, 
"Ao propor que só apoiaria projetos de celulose com capacidade de mais de $100 \mathrm{t} /$ dia, o Banco estava adotando uma atitude pioneira: evitar desperdícios de matérias-primas e energia. Em outras palavras, redução de custos e maior eficiência no processo produtivo. (...) o licor negro (a lixívia), subproduto da fabricação de celulose, além de muito polvente, era matéria-prima recuperável sob a forma de energia e de produtos químicos. (...) Em projetos de menos de $100 \mathrm{t} /$ dia, o subproduto, além de poluir, era desperdiçado, pois nāo justificava a instalação da caldeira de recuperação do licor negro" (BNDES, 1991, p. $11)$.

Tabela 3 - Área aprovada para reflorestamento com recursos dos incentivos fiscais no período de 1967 - 1977

\begin{tabular}{cccc}
\hline Ano & Pinus & Eucalyptus & Araucaria \\
\hline 1967 & 18.159 & 13.877 & 1.729 \\
1968 & 60.899 & 30.057 & 7.330 \\
1969 & 96.798 & 53.800 & 7.670 \\
1970 & 119.913 & 83.609 & 12.029 \\
1971 & 98.053 & 129.053 & 8.080 \\
1972 & 101.059 & 172.441 & 7.756 \\
1973 & 86.181 & 161.132 & 7.828 \\
1974 & 83.245 & 188.336 & 7.530 \\
1975 & 94.222 & 222.718 & 6.618 \\
1976 & 87.001 & 262.337 & 4.845 \\
1977 & 99.277 & 194.352 & 758 \\
\hline
\end{tabular}

FONTE: IBDF/DR

A importância desta medida pode ser compreendida quando se observa que o estudo encomendado pela ANFPC indicava que, em 1967, apenas seis fábricas de celulose no país tinham capacidade maior que 100 ton./dia.

Estas duas medidas foram responsáveis pela criação do que se transformaria no segmento exportador de celulose de mercado. Somente no ano de 1967 houve o surgimento de três importantes players: A Cia. Florestal Monte Dourado, que adquiriu as empresas proprietárias da área de Jari com a finalidade de implementar um projeto de reflorestamento e posterior fábrica de celulose; a Aracruz 
Florestal, que surgiu como uma empresa de prestação de serviços na área de reflorestamento; e a Florestas Rio Doce, controlada pela Cia. Vale do Rio Doce (Soto, 1992).

A partir de 1968, graças a prioridade dada pelo Banco aos projetos no setor de papel e celulose, todos os grupos líderes obtiveram financiamentos do BNDE.

Basta dizer que neste ano 10,7\% das operações aprovadas pelo Banco destinaram-se ao setor. Este grande aumento é explicado pelo apoio ao projeto da empresa Borregaard, o qual teve uma grande importância para a evolução posterior de todo o setor. A dimensão do projeto (500 ton./dia) mostrava, em primeiro lugar, que o mercado mundial passava a apostar na evolução futura do mercado de fibra curta de eucalipto e, em segundo lugar, evidenciava a necessidade de apropriação das economias de escala como fonte principal da competitividade internacional (BNDES, 1991).

Como o projeto representaria cerca de $10 \%$ do valor total da pauta de exportações brasileira no ano de 1967, o BNDE decidiu apoiá-lo, inclusive participando acionariamente do projeto. Isto é, graças ao projeto Borregaard, o Banco iniciou uma política acionária direta em determinados projetos.

No início da década de 70, graças à pressões do BNDE, a Resolução 11/72 do Conselho de Desenvolvimento Industrial (CDI) fixou novas escalas mínimas para que os projetos industriais de produção de celulose recebessem incentivos oficiais. O CDI passou a considerar, para fins de concessão de incentivos, escalas mínimas de 500 ton./dia para a produção de celulose e com expansão prevista para 1.000 ton./dia.

A elevação, em cerca de dez vezes, da escala mínima exigida tinha como principal objetivo criar as condiçōes para o surgimento de um segmento exportador de celulose de fibra curta.

Não obstante, frente às pressões do empresariado, o CDI acabou por permitir que as empresas pudessem alcançar a escala mínima exigida em duas etapas. A primeira, no entanto, deveria atingir um mínimo de 500 ton./dia. 
A Resolução 11/72 constituiu-se num indicativo das intençōes do BNDE. Tratava-se de buscar uma maior eficiência e redução de custos por meio da apropriação das economias de escala, bem como explorar de forma mais intensa as vantagens comparativas brasileiras na produção de celulose de eucalipto (BNDES, 1991).

A crise do petróleo em 1973 só veio reforçar este posicionamento. Frente a brutal elevação dos preços das matérias-primas no mercado internacional, o país, grande importador desses produtos, passou a enfrentar enormes déficits em conta corrente.

A estratégia governamental baseou-se, então, em "completar" o processo de substituição de importaçōes, privilegiando a produção de matérias-primas e bens de capital. Para tanto, o BNDE passou a dispor dos recursos do PIS-Pasep.

No início de 1974, o Conselho do BNDE aprovou o Plano de Ação para o período 1974 - 1978 o qual estabelecia que os projetos que tivessem como objetivo a exportação teriam estímulo prioritário.

Quanto ao setor de papel e celulose, o Plano estabelecia o seguinte (BNDES, 1991, p. 23):

"(...) a meta específica do setor deve levar em conta não só o atendimento do consumo interno, como também a participação mais expressiva do País no mercado internacional.

Nesse sentido, pretende o BNDE dar apoio a projetos de grande porte que concorram para que a economia brasileira atinja um nível de produção de celulose superior a 2,5 milhōes de toneladas em 1978, formando, ao mesmo tempo, a massa crítica que garanta uma capacidade de produção superior a 3 milhōes de toneladas em 1980."

Assim, em 1974, inserido na estratégia do II Plano Nacional de Desenvolvimento (PND), foi elaborado o I Programa Nacional de Papel e Celulose (I PNPC).

O objetivo era alcançar a auto-suficiência tanto em papel quanto em celulose, prevendo para esta última, a geração de excedentes exportáveis.

De acordo com Soto (1992, p. 193), 
"O plano não somente agrupou as medidas de políticas vigentes desde finais dos 60 , como também as complementou e articulou formalmente. Precisou objetivos, definiu metas de produção e exportação, e aperfeiçoou seus mecanismos operacionais. $O$ 'pacote' de políticas contidas no I PNPC, articulou medidas de política agrícola com industriais; a política de financiamento com medidas de fomento às exportaçōes, medidas para o fortalecimento de grandes grupos empresariais nacionais com uma política de atração do capital externo de risco.

As políticas abrangem os segmentos de reflorestamento, produção de celulose e papel, de celulose de mercado e de máquinas e equipamentos."

Elaborado num momento de euforia da economia brasileira e de alta no preço da celulose no mercado internacional, o plano previa a instalação de treze grandes plantas até 1980, baseando-se num modelo tripartite com igual participação do Estado, capital privado nacional e capital privado estrangeiro. Contudo, somente cinco projetos chegaram a ser instalados e coube ao Estado a responsabilidade pela maior parte do investimento (Paladino, 1985).

Assim, novamente o governo, por meio do então BNDE, desempenhou um papel importante na execução de investimentos no setor de papel e celulose.

Conforme Paladino (1985, p. 292),

"[...] o traço característico do desenvolvimento do setor, na segunda metade da década de 70 , foi menos o aumento da participação do capital estrangeiro e mais a participação do Estado nos grandes projetos de produção de celulose.

Isso, entretanto, não permite concluir que ao nível do controle empresarial desses grandes projetos a presença do Estado tenha sido proporcional ao seu aporte de capital, devido as peculiares conformaçōes do capital acionário e dos dispêndios em infra-estrutura."

O BNDE proporcionou uma série de vantagens para as empresas do setor, tais como crédito subsidiado de longo prazo, participação direta no capital das empresas e auxílio à capitalização das empresas privadas nacionais por intermédio de programas especiais. Assim, as empresas líderes receberam financiamento direto subsidiado, participação acionária da FIBASE (posteriormente BNDESPAR) em até 50\% 
do capital, crédito FINAME para aquisição de equipamentos fabricados no país e aval para importação de equipamentos, além de financiamento a acionistas (Soto, 1992).

Tal participação, no entanto, era feita por intermédio da aquisição de ações preferenciais unicamente, pois a filosofia da FIBASE era a de não interferir na administração dos negócios privados. Além do mais, o Banco venderia sua participação, preferencialmente aos acionistas controladores do empreendimento tão logo o projeto amadurecesse. Isto, contudo, não evitou que o Banco fosse levado a tornar-se o controlador e administrador de certas empresas que passaram por dificuldades técnicas de implementação ou insucesso gerencial (BNDES, 1991).

Da exposição acima observa-se, portanto, que o Estado, nas décadas de 60 e 70, por intermédio de sua política de incentivos, determinou várias das condições básicas da oferta do setor de papel e celulose, tais como a tecnologia utilizada, a escala mínima de operação e a integração da parte industrial como o fornecimento da matéria-prima.

$\mathrm{Na}$ década de 70, começaram a operar três grandes empresas produtoras de celulose de mercado: a Borregaard entra em operação em 1972; a Celulose Nipo-Brasileira (CENIBRA) é fundada em 1973 e inicia as operações em 1977; a Aracruz Celulose inicia suas operações em 1978 com uma capacidade de produção que representava, naquela época, $25 \%$ da capacidade nacional de produção de celulose de fibra curta. Além disso, a Cia. Monte Dourado iniciou o processo para a importação do Japão de uma fábrica para a produção de celulose de fibra curta.

É importante ressaltar que o sucesso do BNDES em incentivar a ampliação da indústria brasileira de celulose, principalmente das empresas que elaboram celulose de mercado, deve-se, em parte, a mudanças internacionais ocorridas nesta atividade e que levaram, a partir da década de 60 , várias empresas internacionais a transferirem, para países em desenvolvimento, parte da produção de celulose de que necessitavam ${ }^{16}$. Os incentivos dados pelo BNDES, junto a outros fatores, levaram essas

\footnotetext{
${ }^{16}$ Aspecto esse abordado no item 4.1.
} 
empresas a optarem pelo Brasil no estabelecimento de suas subsidiárias ou de joint ventures com parceiros nacionais.

Na década de 80, a indústria brasileira de celulose alcançou sua maturidade e se consolidou operando com equipamentos compatíveis com a tecnologia mundial e integrados com a produção florestal. A indústria brasileira já era, nessa época, auto-suficiente na produção de matéria-prima florestal plantada e, assim, adaptada a esse tipo de pressão ambiental.

A crise econômica geral que marcou este período não impediu que o BNDES continuasse a financiar investimentos no complexo florestal. Na segunda metade da década iniciou-se um novo ciclo de investimentos na modernização e ampliação de capacidade produtiva na indústria. O segundo Programa Nacional de Papel e Celulose (II PNPC) previa investimentos de cerca de US\$ 9,6 bilhöes para o período de 1987 a 1995, dos quais dois terços destinavam-se para a ampliação da produção de celulose. Ao contrário do I PNPC, lançado em 1974, o segundo plano foi uma iniciativa dos produtores e não do governo. Além disso, incluiu tão somente uma programação de investimentos produtivos sem contemplar um conjunto articulado de medidas como aconteceu na década de 70. Na verdade, o principal objetivo do II PNPC era obter linhas de financiamento de longo prazo do BNDES para viabilizar um novo ciclo de investimentos (Soto, 1992). O início da década de 90 marca uma fase de grandes desembolsos do BNDES ao setor (ver gráfico 3).

Desta forma, o período de 1985 a 1995 marcou o segundo ciclo de investimentos no setor. Foi dentro do II PNPC que se viabilizou a duplicação da capacidade da Aracruz e o projeto Bahia Sul, onde o BNDES participa com capital de risco. Neste período, coube a cada empresa definir o tipo de produção a ser elaborada e que poderia, ou não, adaptar-se às pressōes ambientais comentadas no capítulo anterior. 
Gráfico 3 -Desembolsos do BNDES para o setor de celulose e papel em relação aos desembolsos totais do Banco (valores em \%). 1985 -

1994

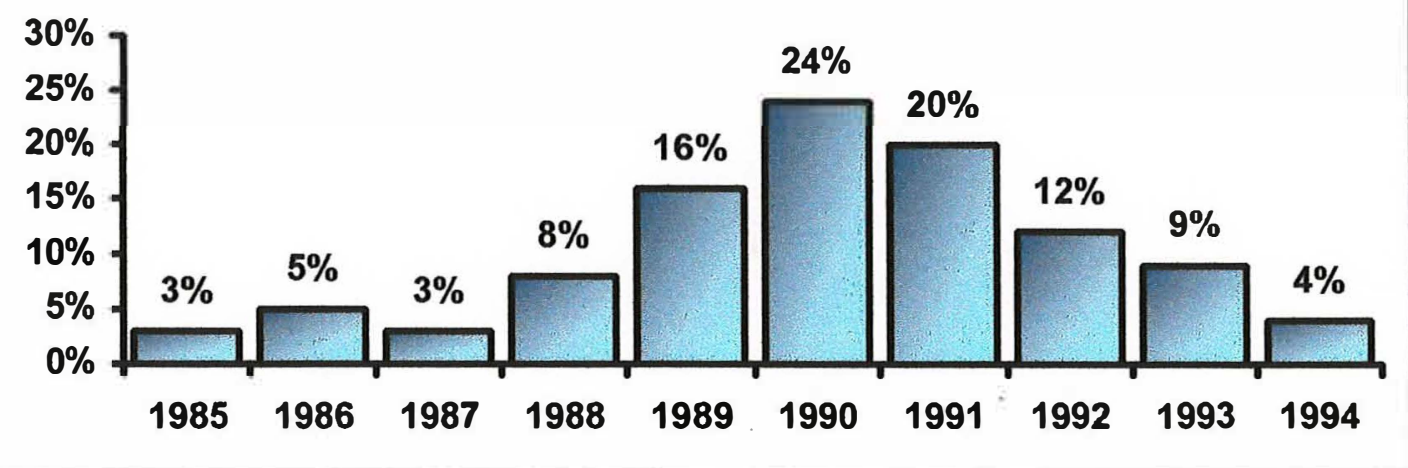

FONTE: Macedo et al. (1995)

Como uma síntese de todo este processo de evolução, o gráfico 4 mostra a evolução da produção brasileira de celulose. Segundo a FAO, em 1961, o país produzia 304.200 toneladas. Em 1970 a produção saltou para 810.700 toneladas. Já em 1980, a produção chegou a 3.089 .000 toneladas. Em 1990, foram 4.307.000 toneladas e em 1998, 6.774.000 toneladas.

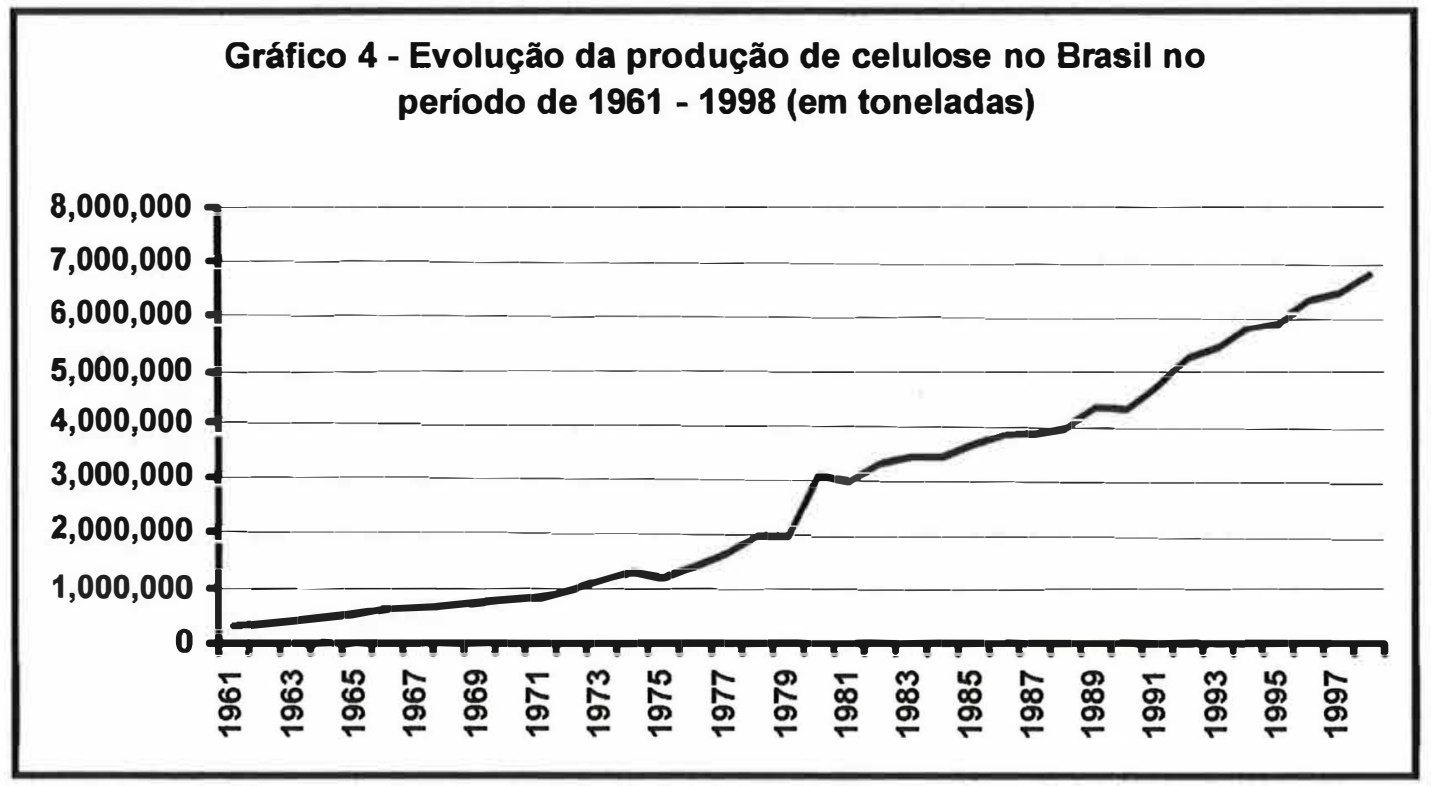

FONTE: http//:unw.fao.org 
Isto significa que a produção cresceu $166,50 \%$ entre 1961 e 1970, $281,03 \%$ no período 1970 - 1980, 39,43\% no terceiro período e, finalmente, $57,3 \%$ entre 1990 e 1998. Cabe ainda ressaltar que o crescimento da produção mundial nestes períodos correspondeu a $65,66 \%, 23,43 \%, 23,24 \%$ e $2,95 \%$, respectivamente, de forma que a produção brasileira de celulose vem sempre crescendo em ritmo muito superior ao mundial.

\subsection{A participação do Brasil no comércio externo de celulose}

Conforme assinalado no item anterior, o apoio oficial ao setor de papel e celulose no Brasil teve como um de seus objetivos a geração de excedentes exportáveis. No presente item, avaliam-se os resultados obtidos nesse sentido e o cenário internacional em que se inserem nossas exportações de celulose.

\section{EVOLUÇĀO DAS EXPORTAÇŌES BRASILEIRAS DE CELULOSE}

Os resultados das políticas de incentivo à indústria brasileira exportadora de celulose pode ser avaliado por seu desempenho exportador. As exportações brasileiras deram um salto considerável a partir de 1978 e o viés exportador do segmento de celulose de mercado pode ser percebido pela evolução das exportações que passaram de 39.600 toneladas em 1970 para 2.526.100 toneladas em 1998 (Gráfico 5). 


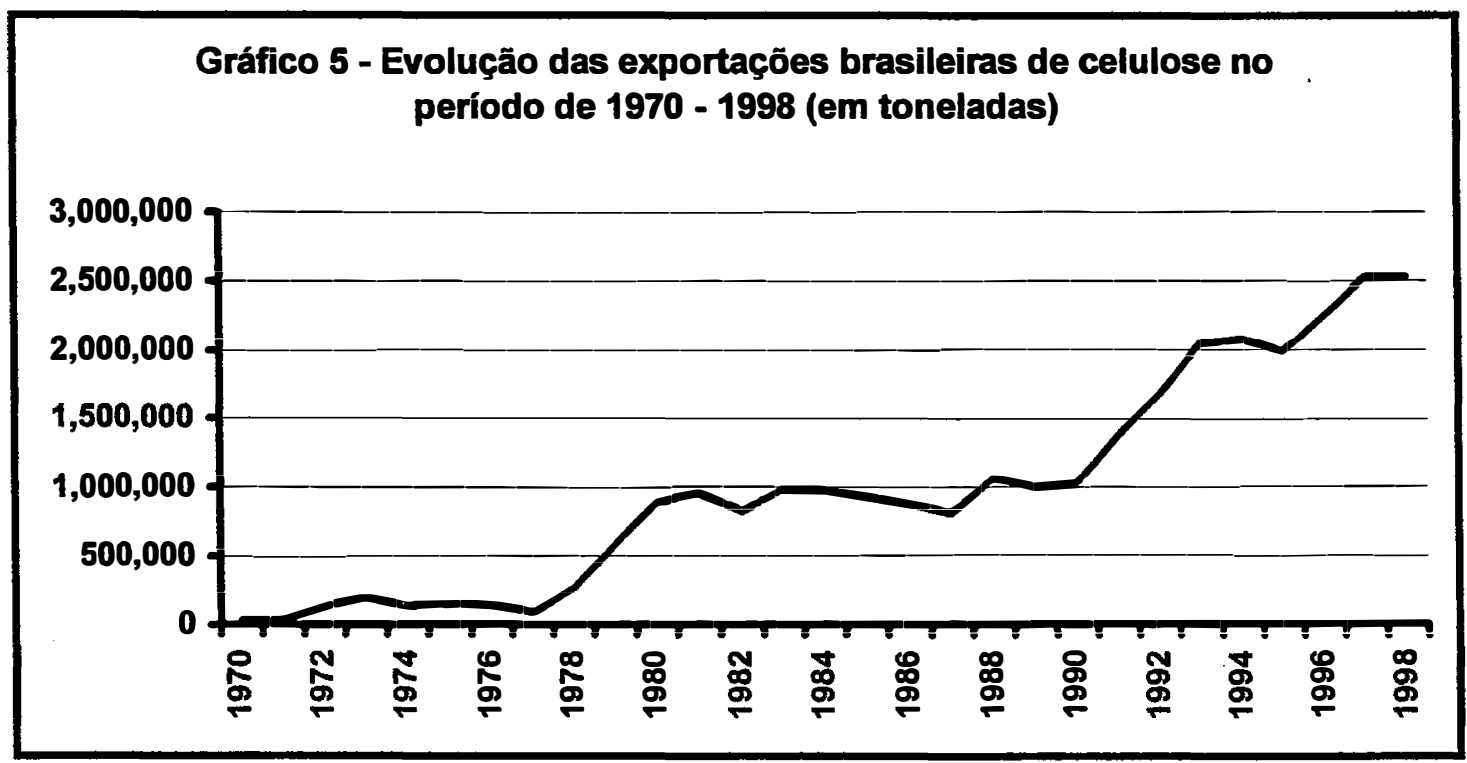

FONTE: http://www.fao.org

No panorama mundial, o Brasil tornou-se o maior produtor de celulose de fibra curta (hardwood pulp) do mundo e também o maior exportador (Tabela 4).

Tabela 4 - Principais produtores e exportadores de celulose de eucalipto no mundo em 1997

\begin{tabular}{lcc}
\hline PAIS & PRODUÇÃO (\%) & EXPORTAÇAO (\%) \\
\hline Brasil & 50 & 45 \\
Portugal & 19 & 20 \\
Espanha & 15 & 17 \\
Chile & 5 & 5 \\
África do Sul & 5 & 4 \\
Outros & 6 & 9 \\
\hline
\end{tabular}

FONTE: Valença \& Mattos (1999a)

Considerando-se o total de celulose produzido (fibra longa e fibra curta), o país é o sétimo maior produtor de celulose no mundo. No entanto, a produção de celulose de fibra longa (softwood pulp) é, na sua maioria, feita por companhias integradas, destinando-se, basicamente, para o mercado interno.

No mercado externo, a concorrência em nível das empresas é mostrada na Tabela 5, refletindo a divisão de mercado mostrada na Tabela 4. 
Tabela 5 - Maiores concorrentes das empresas brasileiras

\begin{tabular}{c|l|l|l|l}
\hline Empresa & Aracruz & Cenibra & VCP & Riocell \\
\hline \multirow{4}{*}{$\begin{array}{c}\text { Maiores } \\
\text { concorrentes }\end{array}$} & Cenibra (Brasil) & Aracruz (Brasil) & Aracruz (Brasil) & Aracruz (Brasil) \\
& Bahtucel (Portugal) & Portucel (Portugal) & Ence (Espanha) & Ence (Espanha) \\
& BCP (Brasil) & Bahia Sul (Brasil) & Celbi (Espanha) & Portucel (Prasil) \\
& VCP (Brasil) & Cenibra (Brasil) & Bahia Sul (Brasil) \\
\hline
\end{tabular}

FONTE: Dados da pesquisa

MERCADOS COMPRADORES DA CELULOSE BRASILEIRA

Quanto aos compradores, os maiores importadores de celulose no mundo, considerando-se o percentual médio de suas importações no período de 1980 a 1998, são os EUA, a Alemanha, o Japão, a Itália, o Reino Unido, a França e a Coréia do Sul (gráfico 6).

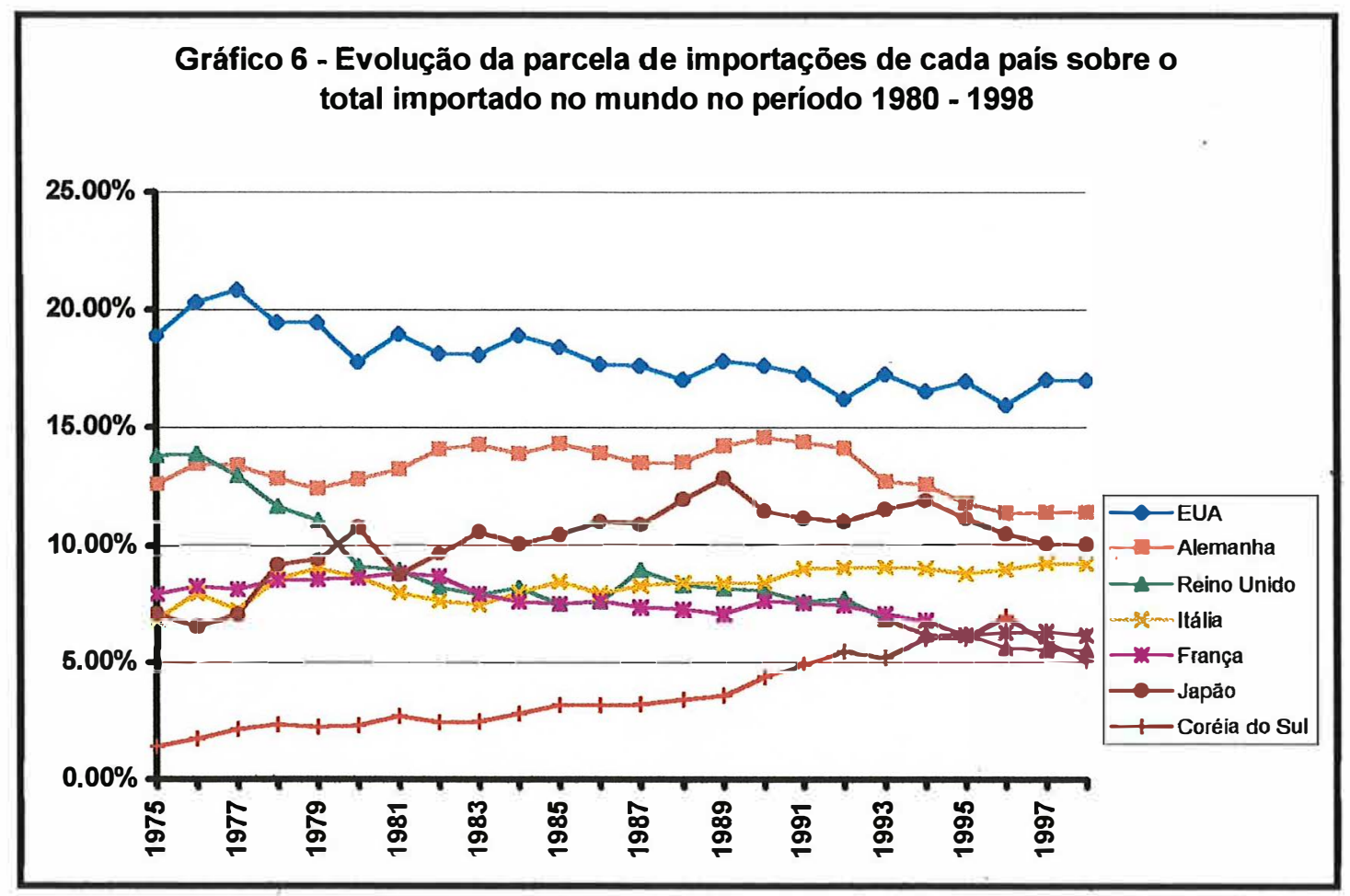

FONTE: hHtp://www.fao.org

A tabela 6 demonstra o destino das exportações de celulose do Brasil. Como seria de se esperar, nossos maiores compradores são aqueles citados acima. No 
entanto, os Países Baixos (Bélgica e Luxemburgo), embora não sejam grandes importadores em termos mundiais, são um importante mercado para o Brasil. De fato, juntando-se a eles, EUA e Japão, observar-se-á que mais de $50 \%$ das exportações brasileiras do produto no período 1989 - 1999 foram destinadas a estes países.

TABELA 6 - Destino das exportaçōes brasileiras de celulose (em mil toneladas) e participação percentual de cada país no total exportado pelo Brasil no periodo $1989-1999$

\begin{tabular}{|c|c|c|c|c|c|c|c|c|c|c|c|c|}
\hline \multirow[t]{2}{*}{ Ano } & \multicolumn{2}{|c|}{ EUA } & \multicolumn{2}{|c|}{$\begin{array}{c}\text { Bélgica e } \\
\text { Luxemburgo }\end{array}$} & \multicolumn{2}{|c|}{ Jopáo } & \multicolumn{2}{|c|}{ Reino Unido } & \multicolumn{2}{|c|}{ Coréia do Sul } & \multicolumn{2}{|c|}{ Outros países } \\
\hline & Volume & $\begin{array}{l}\% \text { no } \\
\text { total }\end{array}$ & Volume & $\begin{array}{l}\% \text { no } \\
\text { total }\end{array}$ & Volume & $\begin{array}{l}\% \text { no } \\
\text { total }\end{array}$ & Volume & $\begin{array}{l}\% \text { no } \\
\text { total }\end{array}$ & Volume & $\begin{array}{l}\% \text { no } \\
\text { total }\end{array}$ & Volume & $\begin{array}{l}\% \text { no } \\
\text { total }\end{array}$ \\
\hline 1989 & 280 & 27,94 & 264 & 26,32 & 212 & $2 d, 16$ & 45 & 4,44 & 17 & 1,73 & 182 & 18,15 \\
\hline 1990 & 331 & 31,88 & 276 & 26,54 & 207 & 19,95 & 51 & 4,92 & 33 & 3,17 & 149 & 14,34 \\
\hline 1991 & 440 & 31,84 & 344 & 24,85 & 249 & 17,99 & 76 & 5,48 & 72 & 5,20 & 225 & 16,25 \\
\hline 1992 & 476 & 28,35 & 436 & 26,00 & 241 & 14,35 & 104 & 6,20 & 107 & 6,39 & 360 & 21,43 \\
\hline 1993 & 575 & 23,88 & $530^{\circ}$ & 21,98 & 353 & 14,66 & 124 & 5,13 & 149 & 6,18 & 726 & 30,10 \\
\hline 1994 & 564 & 27,19 & 460 & 22,20 & 343 & 16,54 & 119 & 5,74 & 114 & 5,50 & 480 & 23,13 \\
\hline 1995 & 592 & 29,82 & 458 & 23,11 & 328 & 16,55 & 126 & 6,36 & 96 & 4,86 & 412 & 20,75 \\
\hline 1996 & 582 & 25,98 & 459 & 20,51 & 362 & 16,18 & 166 & 7,41 & 204 & 9,11 & 496 & 22,12 \\
\hline 1997 & 605 & 24,17 & 367 & 14,66 & 470 & 18,75 & 212 & 8,45 & 134 & 5,33 & 795 & 31,72 \\
\hline 1998 & 682 & 24,30 & 441 & $15,7 i$ & 422 & 15,03 & 228 & 8,13 & 136 & 4,86 & 942 & 33,56 \\
\hline 1999 & 810 & 26,04 & 442 & 14,22 & 427 & 13,72 & 226 & 7,25 & 161 & 5,18 & 1071 & 34,44 \\
\hline
\end{tabular}

FONTE: SECEX

Os outros mercados importantes, tais como ltália, França e Alemanha, absorveram algo em torno de $15 \%$ das exportações de celulose do Brasil.

Por outro lado, é interessante observar a recente diversificação de mercados para a celulose brasileira nos últimos anos. Em 1990, por exemplo, os oito maiores compradores absorviam juntos quase $95 \%$ das exportações. Mais recentemente, nos últimos três anos, nota-se que as exportações brasileiras alcançaram um maior número de países, embora a demanda pela celulose brasileira ainda seja fortemente determinada por um número reduzido de compradores.

Do ponto de vista das empresas individuais, os maiores países compradores são indicados na tabela 7. 
Tabela 7 - Maiores compradores da celulose brasileira por empresa

\begin{tabular}{c|llll}
\hline Empresa & Aracruz & Cenibra* & VCP & Riocell \\
\hline \multirow{4}{*}{ Países } & EUA & Japáo & EUA & Coréia \\
compradores & Alemanho & Europa & Alemanha & Itália \\
& Reino Unido & EUA & Áustria & França \\
& França & Ásia & Itália & Alemanha \\
& Áustria & América Latina & & Argentina \\
\hline
\end{tabular}

FONTE: Dados da pesquisa

NOTA: A Cenibra não forneceu, individualmente, os países compradores para as regiōes mostradas no tabela.

As tabelas 8 e 9 mostram as principais características dos principais compradores da celulose brasileira. A partir dos dados ali contidos pode-se observar que os EUA, nosso maior comprador, é capaz de produzir praticamente toda a celulose que consome, no entanto, dado o tamanho de sua economia, tanto suas exportações de celulose quanto suas importações têm uma importância bastante significativa nos fluxos de comércio do produto. $O$ mesmo acontece com papel e papelão, pois o país possui a maior capacidade de produção do planeta, a qual é capaz de suprir quase a totalidade de seu consumo aparente de papel e papelão.

Quanto a Bélgica-Luxemburgo, a produção de celulose equivale a metade de seu consumo aparente. Na produção de papel e papelão, embora o país tenha dobrado sua capacidade de produção entre 1985 e 1998, o elevado consumo per capita destes itens, aliado a ainda pequena capacidade instalada, faz com que 0 país produza apenas algo em torno de $55 \%$ de seu consumo aparente de papel e papelāo.

O Japão, por sua vez, produz pouco mais que $3 / 4$ de seu consumo aparente de celulose, mas, da mesma forma que os EUA, o tamanho relativo de sua economia faz com ele se torne um grande importador. Não obstante, ao contrário deste último, o país não é um grande player no mercado internacional de papel e papelão.

No que diz respeito ao Reino Unido, há uma grande dependência da celulose importada uma vez que somente $1 / 4$ do consumo aparente é produzido internamente. $O$ mesmo acontece com papel e papelão, cuja produção supre apenas pouco mais da metade do consumo aparente. 


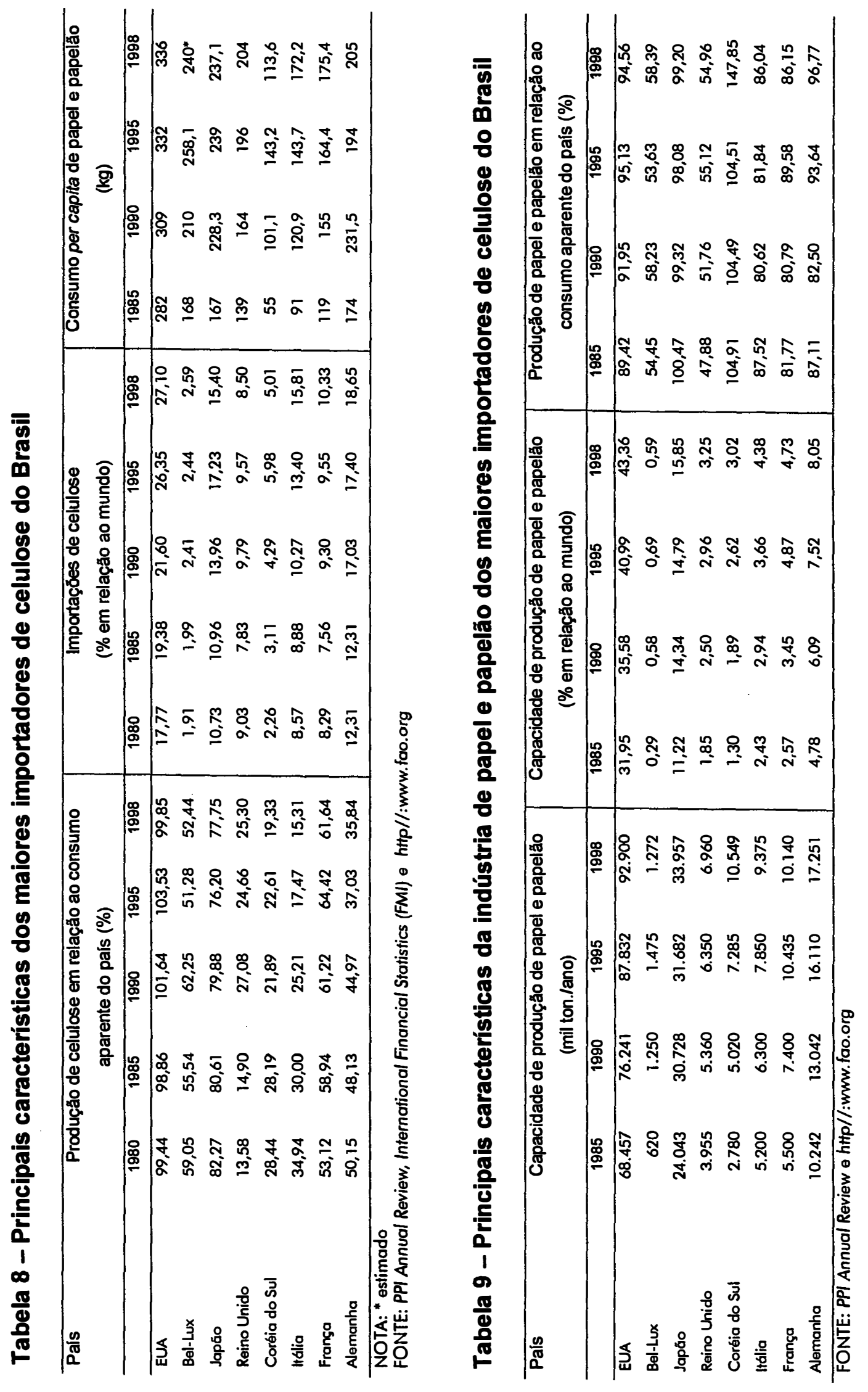


Outros países bastante dependentes da celulose importada são a Coréia do Sul, a Itália a França e a Alemanha. Destes, apenas a França vem diminuindo suas necessidades. Os demais apresentam um volume de produção cada vez menor em relação a seu consumo. A Coréia do Sul, por exemplo, é um grande exportador de papel e papelão e praticamente quadruplicou sua capacidade instalada de produção entre 1985 e 1998. Aliado a isto, o forte crescimento da sua economia fez com que o consumo per capita destes insumos praticamente dobrassem no período.

A Alemanha continua grandemente dependente de importaçōes de celulose e, dado o tamanho de sua economia, ela torna-se um dos maiores importadores do mundo. De modo semelhante aos EUA, o país apresenta uma grande capacidade de produção de papel e papelão (cerca de $8 \%$ da capacidade mundial) e também é um grande player neste mercado, sendo responsável por $8 \%$ do total exportado e, ao mesmo tempo, por algo em torno de $10 \%$ do total importado.

\section{OS PRINCIPAIS CONCORRENTES DO BRASIL NO COMÉRCIO EXTERIOR DE CELULOSE}

No âmbito mundial, destacam-se, como grandes produtores - e, portanto, concorrentes do Brasil - , a América do Norte, a Comunidade Européia, a Escandinávia, a Península lbérica, além de países como a África do Sul e Chile.

De acordo com BNDES (1993, p. 29),

"(...) os líderes mundiais ainda são as economias desenvolvidas. A proximidade dos principais mercados consumidores (Europa, América do Norte e Japão) confere às empresas que operam nestes países vantagens competitivas estruturais, tais como: custos de comercialização e distribuição menores, integração com redes de distribuição e maior possibilidade de interação com o mercado final (o que permite a adoção de estratégias do tipo full satisfaction). Outras vantagens competitivas estão associadas a melhores condiçōes de infra-estrutura física e científico-tecnológica, maior interação com fabricantes de equipamentos e possibilidades de se favorecer de políticas protecionistas que venham a ser adotadas."

A América do Norte é o maior mercado produtor e consumidor. Nos EUA, a indústria de papel e celulose é vinculada à indústria de construção civil e indústria madeireira, de sorte que a produção de celulose é um subproduto da madeira 
serrada, cujos preços chegam a ser até cinco vezes maiores que da madeira para celulose. Este país, no entanto, sofre pressōes de custo crescentes. Na costa oeste, sobressaem a inexistência de madeira, as pressōes ambientais e a queda no rendimento das florestas mais novas. No Sul, há o problema do custo elevado das terras e da exaustão das florestas nativas. O Canadá, por sua vez, passou a enfrentar os problemas de escassez potencial de recursos florestais de alta qualidade e pressão dos ambientalistas para que as florestas públicas não sejam exploradas para fins industriais (BNDES, 1993).

Não obstante, EUA e Canadá juntos, detinham, como pode-se depreender da Tabela 10, mais de $46 \%$ do market share relativo às exportaçōes mundiais. Estes dois países, aliados aos países escandinavos, controlam o mercado mundial por intermédio do cartel NORSCAN.

Os países escandinavos têm grandes vantagens competitivas, por conta de seu grande potencial financeiro, liderança tecnológica, maior valor agregado dos produtos e liderança de mercado, especialmente na distribuição. Além disso, a forte associação com os fabricantes de equipamentos proporcionou às empresas tornarem-se líderes na produção de tecnologias mais amigáveis do ponto de vista ambiental (BNDES, 1993).

Porém, conforme BNDES (1993, p. 31),

"Nos anos setenta e como [sic] maior intensidade nos anos oitenta, a indústria escandinava passou a sofrer uma crescente competição no mercado europeu de países como os EUA, Canadá, Brasil, Portugal e África do Sul. Todos estes produtores apresentavam custos de produção mais baixos e passaram a pressionar aquela indústria. A perda de competitividade da celulose produzida naqueles países levou a uma reação das empresas escandinavas. A principal estratégia foi a verticalização em direção à produção de papel, que se deu através da integração das plantas existentes e de processos vigorosos de reestruturação patrimonial, através da aquisição de empresas e pela fusão e/ou criaçāo de joint ventures. Ao mesmo tempo, a indústria procurou estabelecer negócios nos países que emergiram no cenário internacional, tais como Brasil, Chile e Portugal."

Os demais players têm suas características principais delineadas na

Tabela 10. 


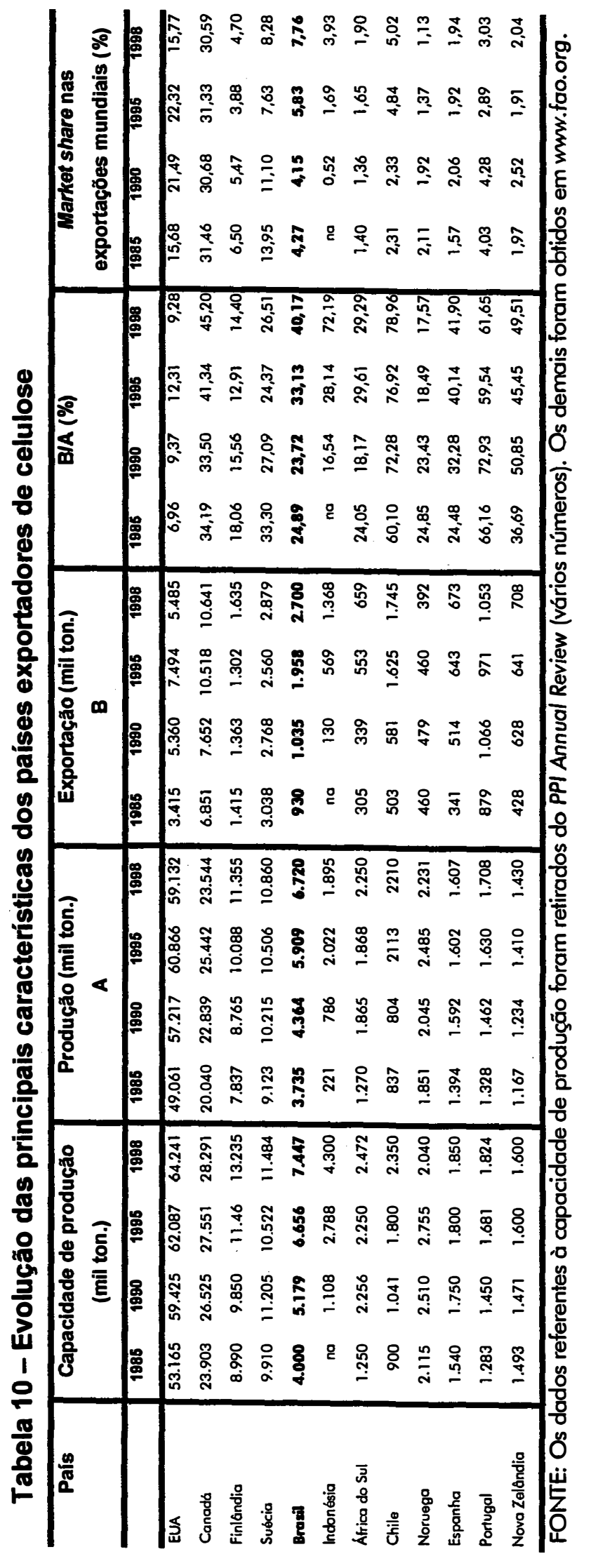




\section{A ORGANIZAÇÃO ATUAL DA INDÚSTRIA BRAȘILEIRA DE CELULOSE}

Este capítulo examina a estrutura, conduta e desempenho da indústria brasileira de celulose observando como esses componentes foram afetados pelas alteraçōes nas condiçōes básicas de demanda e oferta no contexto mundial (examinadas no capítulo 4) e pelas políticas públicas brasileiras (examinadas no capítulo 5). Atenção especial é dada à avaliação dos impactos ambientais sobre a conduta e o desempenho das empresas brasileiras exportadoras de celulose.

\subsection{A estrutura da indústria brasileira de celulose}

Conforme já dito, um de nossos objetivos é determinar as mudanças na conduta da indústria brasileira exportadora de celulose frente a mudanças nas condiçōes básicas de demanda, particularmente no que diz respeito às exigências ambientais. Não obstante, as estratégias adotadas pelas empresas guardam relação direta com as características do mercado no qual elas estão inseridas.

Portanto, faz-se necessário o conhecimento destas características para uma melhor compreensão das possibilidades e limites das estratégias (conduta) das empresas.

De acordo com a figura 1, no capítulo 3, os aspectos importantes para a análise da estrutura de mercado são o número de vendedores e compradores, a 
diferenciação do produto, as barreiras à entrada, a integração vertical e a diversificação da produção.

\section{CONCENTRAÇĀo}

Primeiramente, é importante notar que "a competição na indústria de celulose se dá pela associação de preços com qualidade do produto. As escalas de produção das novas plantas são cada vez maiores, exigindo vultosos investimentos que, associados à disponibilidade de matéria-prima florestal, constituem-se nas principais barreiras à entrada" (Macedo et al., 1995, p. 70).

Não obstante, o número de empresas participantes do mercado foi em grande parte influenciado pela política de escalas mínimas do BNDES, de forma que o setor de celulose já nasceu oligopolizado. Convém lembrar que a intenção primeira do governo era criar um segmento exportador de celulose de mercado e, para tanto, era necessário um volume de produção que capacitasse as empresas nacionais a enfrentar a concorrência extema.

Os maiores produtores brasileiros de celulose são mostrados na tabela 11. Da tabela pode-se observar que a razão de concentração das quatro maiores empresas é $C R_{4}=0,548$.

Tabela 11 - Principais produtores brasileiros de celulose - 1997

\begin{tabular}{lccc}
\hline \multicolumn{1}{c}{ Empresa } & Produção (mil ton) & \% do total & \% acumulado \\
\hline 1. Aracruz & 1058 & 17,6 & 17,6 \\
2. Grupo Klabin & 914 & 15,2 & 32,8 \\
3. Cenibra & 720 & 11,9 & 44,7 \\
4. VCP (Notorantim) & 607 & 10,1 & 54,8 \\
5. Bahia Sul & 503 & 8,3 & 63,1 \\
6. Suzano & 421 & 7,0 & 70,1 \\
7. Champion & 315 & 5,2 & 75,3 \\
8. Ripasa & 296 & 4,9 & 80,2 \\
9. Igaras & 286 & 4,7 & 84,9 \\
10. Rigesa Celulose & 184 & 3,1 & 88,0 \\
11. Jari Celulose & 131 & 2,2 & 90,2 \\
12. Outros & 597 & 9,9 & 100,0 \\
\hline
\end{tabular}

FONTE: CITICORP (1998) 
A produção de celulose de mercado é concentrada em sete grandes companhias, a saber, Aracruz, Cenibra, Bahia Sul, Jari Celulose, VCP e Riocell (Grupo Klabin). De acordo com o BNDES (1999b), seis delas são responsáveis pela totalidade das exportações brasileiras, como mostra o gráfico 7.

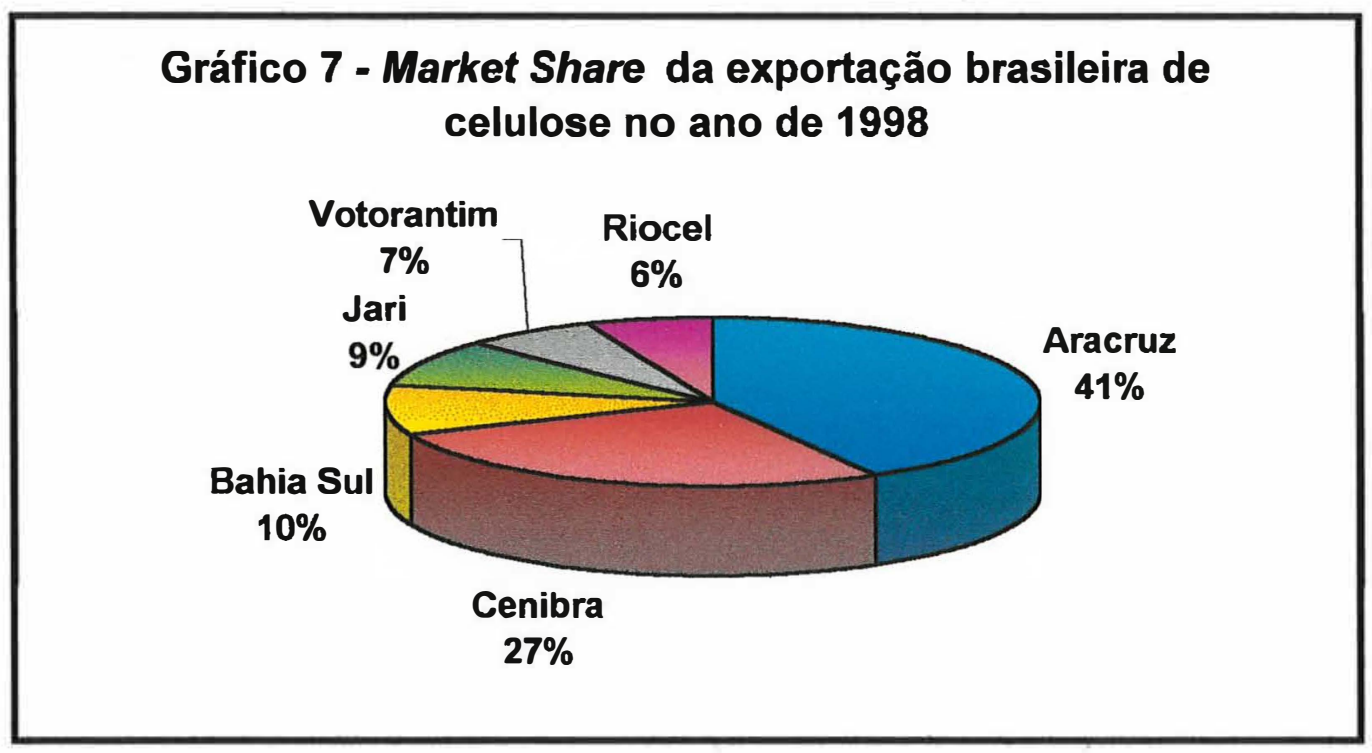

FONTE: BNDES (Valença \& Mattos, 1999b)

As principais características das empresas exportadoras de celulose de mercado são mostradas no quadro 3. 


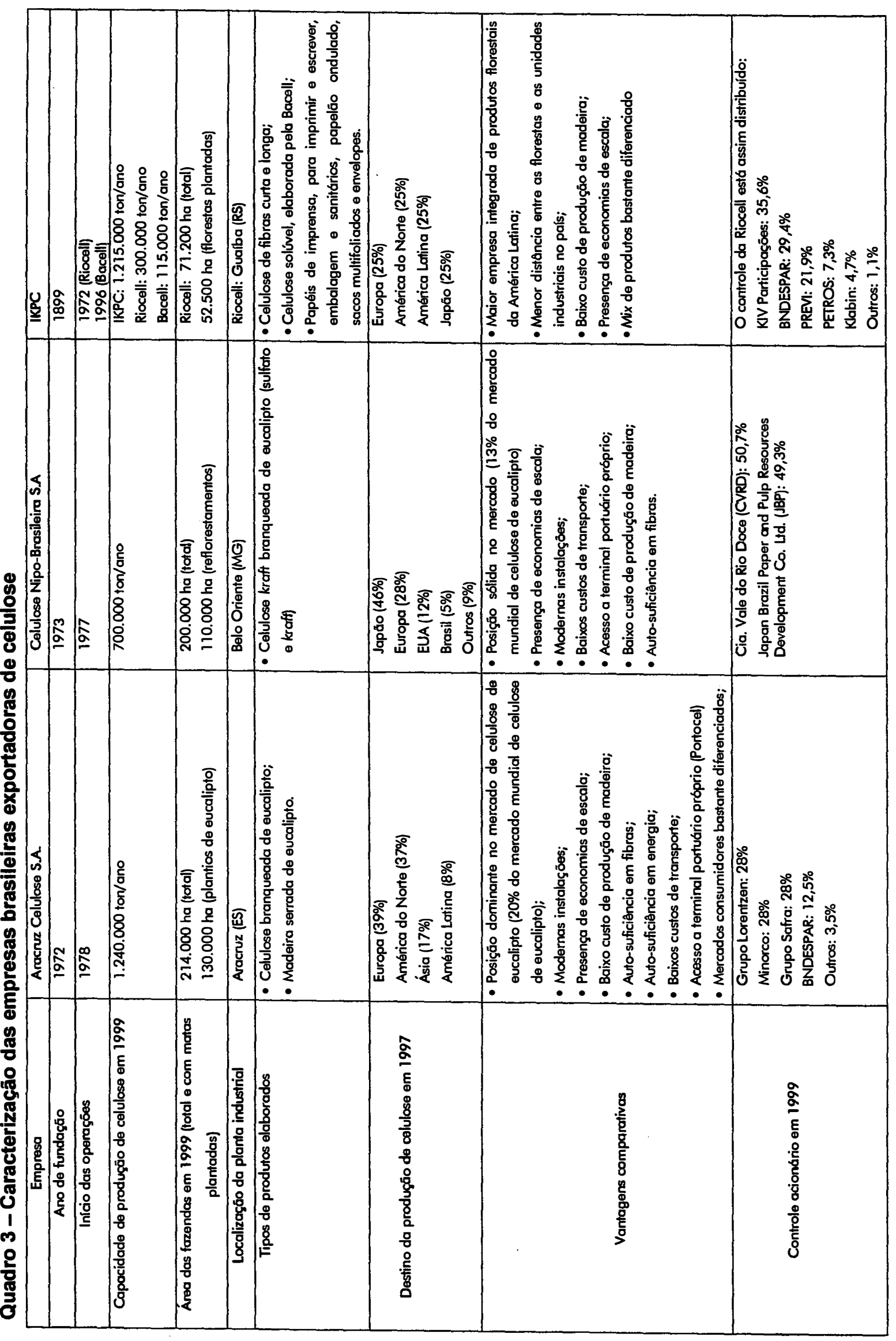




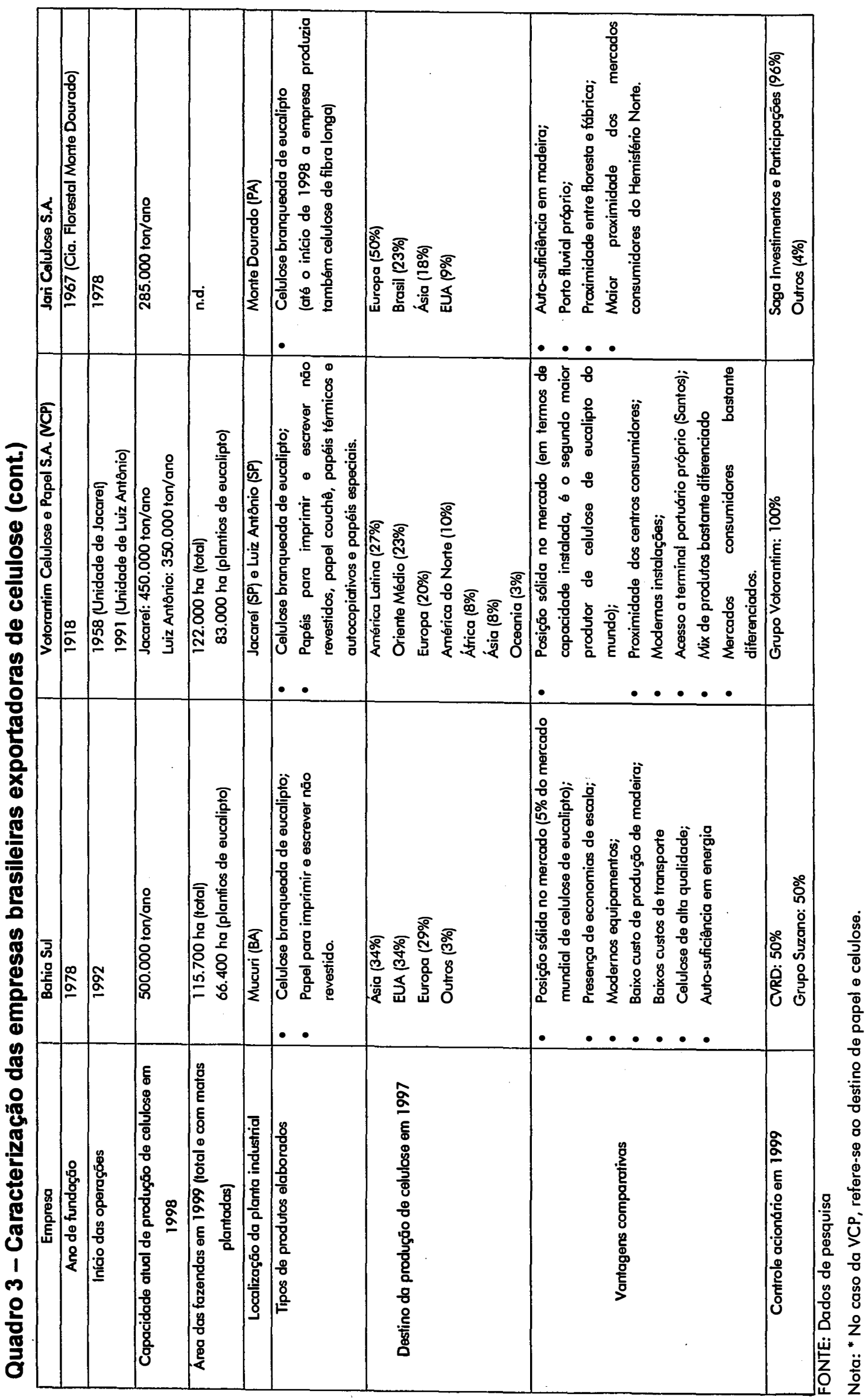


Além destas empresas, existem outros participantes potenciais no mercado, pois o Grupo Odebrecht, associado à Stora-Enso, está desenvolvendo o projeto Veracruz, com uma capacidade de produção de $750 \mathrm{mil}$ ton/ano para entrar em operação em 2001 no extremo sul da Bahia. Ao mesmo tempo, a Celmar, jointventure formada pela Cia. Vale do Rio Doce - CVRD (42,5\%), Ripasa (42,5\%) e Nissho Iwai (15\%), com capacidade para 500 mil ton/ano também planeja entrar em operação em 2001 no Maranhão. Outras intençōes de investimentos em celulose de mercado são a Norcell (associação dos grupos Klabin e Copene) e a Champion, no Mato Grosso do Sul, com fábricas planejadas para $420 \mathrm{mil}$ e $750 \mathrm{mil} \mathrm{t/ano,} \mathrm{respectivamente,} \mathrm{as}$ quais não possuem ainda data prevista para início de operação (Macedo \& Mattos, 1996; Mattos \& Valença, 1999).

\section{DIFERENCIAÇĀO DO PRODUTO}

Já no que diz respeito à questão da diferenciação de produto, as empresas vêm tentando responder às pressōes ambientais por meio da obtenção de certificados de aceitação internacional, baseados num adequado manejo florestal e na utilização de processos de branqueamento da celulose que não utilizam o gás cloro (cloro elementar). Tais estratégias, bem como o contexto em que elas estão inseridas, serão melhor explorados adiante.

Não obstante, as empresas também procuram diferenciar seu produto pela qualidade e prestação de serviços de assistência técnica, além de buscar a diminuição dos custos para a celulose entregue ao cliente. Para tanto, a estrutura de comercialização e a escala de produção são os fatores-chave (BNDES, 1996, p. 4).

\section{INTEGRAÇĀO VERTICAL E BARREIRAS À ENTRADA}

Por outro lado, um dos fatores importantes para a análise da estrutura da indústria brasileira de celulose é a questão da integração vertical. Conforme visto anteriormente, Porter (1991) considera que quando existem vantagens econômicas na integração vertical para trás, esta acaba por constituir-se em uma barreira à entrada, 
pois os novos competidores devem entrar no mercado também de forma integrada, a fim de evitarem dificuldades na aquisição de insumos de produção.

No caso brasileiro, como já dito, para incentivar o reflorestamento, o governo promulgou o DL 5.106/66, permitindo que as pessoas físicas pudessem obter descontos no Imposto de Renda, abatendo da renda bruta as importâncias efetivamente aplicadas em reflorestamento. Para as pessoas jurídicas o mesmo decreto permitia abater até $50 \%$ do Imposto de Renda devido com os gastos efetivamente realizados com reflorestamento.

Em 1970, no entanto, o governo proporcionou uma alternativa ao DL 5.106/66 para as pessoas jurídicas: 0 DL 1.134/70 permitiu o abatimento das despesas com reflorestamento no Imposto de Renda antes de se efetivarem (respeitado o limite de $50 \%$ e incluindo-se outros abatimentos), além disso, permitiu a conjugação de dois ou mais investidores num mesmo projeto de reflorestamento. $O$ objetivo de tal decreto era acelerar o processo de reflorestamento, possibilitando às empresas abater do Imposto de Renda a quantia que desejavam investir antes de gastarem (Bacha, 1991).

Por conseguinte, sob o estímulo desta legislação, entre 1966 e 1970 surgiram inúmeras pequenas e médias empresas de reflorestamento, movidas muito mais pelo objetivo de recuperar parcelas do Imposto de Renda do que com fins produtivos (Soto, 1992).

Até 1974 houve uma expansão desordenada de empresas florestais "independentes", isto é, não vinculadas à indústria, que executaram um grande número de pequenos projetos dispersos por todo o país. A partir deste ano são realizados projetos de reflorestamento de grande escala, sob a responsabilidade direta do setor de papel e celulose (Soto, 1992).

Conforme assinala Bacha (1991, p. 150),

"De 1966 a 1976, os incentivos fiscais para o reflorestamento foram concedidos sem impor restrições de áreas. Isto gerou o problema de criar áreas reflorestadas em lugares inapropriados ao uso industrial. Em 1975 foram criados os distritos florestais, que são áreas selecionadas para 0 reflorestamento, considerando sua aptidão agrícola e a localização das indústrias. Pelo Decreto-Lei $n^{\circ} 1.503$ e o Decreto $n^{\circ} 79.046$, no final de 
1976, ficou estabelecido que os recursos fiscais para o reflorestamento só seriam concedidos para áreas selecionadas, como os distritos florestais."

A partir daí, as atividades florestais vão gradativamente sendo subordinadas aos interesses industriais, num processo que se completa na década de 80. De acordo com a análise de Soto (1992, p. 169-170), a venda de florestas implantadas por reflorestadores independentes deveu-se a vários mecanismos:

(a) barreiras que impediram a entrada dos reflorestadores independentes na produção de celulose e papel;

(b) proibição oficial das exportações de madeira de eucalipto e pinus;

(c) ausência de controles oficiais dos preços da madeira que proporcionassem níveis de renda adequados aos reflorestadores ${ }^{17}$;

(d) o controle oligopsônico do mercado de madeira, responsável pelo aviltamento dos preços, na medida que as empresas compradoras passaram a utilizar seus estoques para regular os preços; $\mathrm{e}$,

(e) a criação de um mercado de títulos, no qual os benefícios obtidos num primeiro instante pelo investidor que optava pelas deduções no imposto de renda eram posteriormente transferidos para as empresas industriais, que adquiriam tais títulos por preços substancialmente inferiores aos de mercado, proporcionando a aquisição de ativos florestais em condições extremamente vantajosas.

A conseqüência disto foi que os reflorestadores independentes tiveram que escolher entre vender suas áreas florestais às empresas produtoras de papel e celulose, sob as condiçōes destas últimas, ou simplesmente abandonar as florestas localizadas em áreas onde os preços da madeira não compensavam os custos de transporte.

\footnotetext{
17 Os produtores, por meio da Associação Nacional dos Fabricantes de Papel e Celulose (ANFPC), conseguiram que a madeira nunca estivesse relacionada entre os produtos sujeitos aos controles oficiais de preços enquanto que a celulose tinha preços oficiaimente controlados. Assim, de um lado, os produtores conseguiam negociar seus preços junto ao governo, garantindo sua lucratividade e, de outro, os reflorestadores independentes enfrentavam um mercado oligopsônico para a madeira, de tal sorte que não eram capazes de obter níveis de renda satisfatórios.
} 
Desta forma, uma parcela bastante importante dos recursos repassados aos reflorestadores independentes acabou por ser transferida aos setores consumidores de madeira, graças, sobretudo, ao seu poder de mercado. Assim, das 900 empresas reflorestadoras independentes no início da década de 70, restavam apenas 50 no início da década de $90^{18}$.

Durante a década de 80 , as principais empresas industriais dedicaram-se muito mais ao melhoramento tecnológico e aumento da produtividade nos reflorestamentos adquiridos de terceiros do que a um aumento na área plantada. $E$ ́ importante também notar que a reformulação de projetos (reforma de plantios) permitia o reconhecimento oficial de mudança de administração, de forma a habilitar os novos proprietários a receber, novamente, incentivos fiscais. Tal fato acabava por estimular ainda mais as empresas de papel e celulose a adquirir florestas implantadas por terceiros.

Com base na análise acima, Soto (1992, p. 176 - 7) acaba por concluir que

\begin{abstract}
"A principal responsabilidade pelo barateamento dos custos de produção da madeira está na forma como foi desenhado e executado o programa de incentivos fiscais ao reflorestamento, muito mais do que as tão frisadas 'vantagens naturais' excepcionais do país. Os baixos custos da madeira explicam boa parte da enorme lucratividade dos empreendimentos industriais e das vantagens competitivas do setor a nivel internacional."
\end{abstract}

De qualquer forma, frente a esta situação, qualquer empresa que tencione entrar no mercado deverá fazê-lo de forma integrada, pois, de outra forma, não irá dispor de matéria-prima para operar. Esta situação é, ao mesmo tempo, mais uma barreira que as empresas entrantes deverão superar e uma vantagem competitiva das empresas que já atuam no mercado, frente aos concorrentes internacionais. Além do mais, as empresas já estabelecidas, graças aos mecanismos de subsídio acima comentados, possuem, conforme já assinalado por Porter (1991), vantagens de custos

\footnotetext{
${ }^{18}$ Segundo relato de Luiz C. Ramires, proprietário de uma empresa reflorestadora, citado em Soto (1992, p. 171)
} 
impossiveis de serem igualadas, independentemente da escala com que os novos entrantes venham a operar.

\section{DIVERSIFICAÇĀO DA PRODUÇĀO}

Por outro lado, a integração para a frente, diversificando os produtos elaborados, poderia ser uma estratégia a ser adotada pelas empresas produtoras de celulose de mercado. No entanto, ao se observar a tabela 12, nota-se que, de todas as empresas exportadoras de celulose de mercado, a Aracruz e a Cenibra não estão envolvidas na produção de papel. As demais empresas pertencem a grupos que já atuam neste segmento.

Tabela 12 - Segmentos de atuação dos principais grupos envolvidos na produção de celulose de mercado

\begin{tabular}{|c|c|c|c|c|c|c|c|c|}
\hline & \multirow{2}{*}{$\begin{array}{c}\text { CeLULOSe } \\
\text { CELULOSE DE } \\
\text { MERCADo }\end{array}$} & \multicolumn{6}{|c|}{ PAPÉS } & \multirow{2}{*}{$\begin{array}{c}\text { MADEIRA } \\
\text { SóLIDOS DE } \\
\text { MADEIRA }\end{array}$} \\
\hline & & INPRENSA & $\begin{array}{l}\text { IIPRIIIAR E } \\
\text { ESCREVER }\end{array}$ & EMBALAGEM & SANTTÁRIO & CARTĀO & ESPECIAIS & \\
\hline $\begin{array}{l}\text { Aracruz } \\
\text { Cenibra } \\
\text { Bahia Sul } \\
\text { Jari } \\
\text { VCP } \\
\text { Klabin } \\
\text { Suzano }\end{array}$ & $\begin{array}{c}* * * \\
* * * \\
* * * \\
* * * \\
* * * \\
\square \\
\square\end{array}$ & $\Xi$ & $\begin{array}{c}* * * \\
\square \\
\square * *\end{array}$ & $* * *$ & $\begin{array}{c}* * * \\
\square\end{array}$ & $\begin{array}{c}\square \\
* * * \\
* * *\end{array}$ & $\begin{array}{c}* * * \\
\square\end{array}$ & $\square$ \\
\hline
\end{tabular}

FONTE: Adaptado de Mattos \& Valença (1999)

NOTA: ${ }^{* * *}$ Atividade principal

口 Atividade secundária

No final de dezembro de 1999, a Jari foi adquirida pela Saga Investimentos e participaçōes, holding do Grupo Orsa que já atua no segmento de papel ondulado.

Especificamente no caso da Aracruz Celulose, é interessante, recorrer à análise de Soto (1992) para tentar explicar o porquê da não integração na produção de papel.

De acordo com ele, o projeto Aracruz foi concebido no início da década de 70, mas somente em 1975, com a participação maciça do BNDES, é que ele se tornou viável. O sistema BNDES utilizou-se de todas as suas modalidades operacionais de financiamento para tornar o projeto exeqüível. No entanto, a determinação oficial 
em criar um segmento produtor de celulose de mercado no país e particularmente da empresa Aracruz, implicava na entrada de novos grupos empresariais no complexo produtor de papel e celulose. Além disso, a execução do projeto significava promover um tratamento discriminatório na distribuição dos recursos públicos entre as empresas do setor.

Para um observador do setor, a Aracruz surgiu não como uma ampliação produtiva de um grupo nacional. Ela foi constituída por empresários de outros setores que, a partir do acesso aos recursos do BNDES, ameaçaram a posição hegemônica dos grandes produtores tradicionais. Estes sentiam-se ameaçados, pois o próximo passo poderia ser a produção de papel pela Aracruz, o que, dada sua capacidade produtiva, colocaria os demais fabricantes numa posição de grande inferioridade.

Esta ameaça tornou-se real a partir de negociações mantidas entre a Aracruz e a International Paper, líder mundial na produção de papel. Porém, nas palavras de Soto (1992, p. 228):

"Com os preços internacionais da celulose em alta os interesses do Estado apontavam para a exportação de celulose. Esta tinha condições de competitividade internacional inatingíveis pelo papel, que enfrentava maior concorrência. Por isso o Estado fez uso do seu controle acionário na empresa para impedir sua associação com a IP. A não entrada da Aracruz no mercado de papéis é um trunfo através do qual o Estado conseguiu que a ANFPC diminuisse suas resistências à iniciativa de criar um segmento de celulose de mercado. $O$ Estado até conseguiu seu apoio formal, apesar de que as empresas tradicionais continuaram em desvantagem na distribuição de benefícios públicos, em especial no financiamento do BNDES. Basta lembrar que a Aracruz recebeu no período 1970 - 1990 um financiamento total maior que a soma do recebido pelos quatro grupos líderes da indústria integrada, cujos interesses controlavam a ANFPC" (grifo nosso).

Não obstante, atualmente a Aracruz está investindo na área de madeira sólida, buscando usos alternativos para suas florestas de eucalipto como forma de diluir os riscos do negócio de celulose, pois o mercado de madeiras duras desfruta de ciclos favoráveis exatamente quando o mercado de celulose está em baixa. 
Inicialmente, o empreendimento, constituído no primeiro semestre de 1997, era uma joint venture entre a Aracruz (60\%) e a Gutchess (40\%), com o nome de Tecflor Industrial. No entanto, frente à crise asiática, a empresa norte-americana saiu da parceria e a Aracruz acabou comprando a parte do sócio, garantindo, porém, o suporte tecnológico (Hasse, 1999).

A Aracruz Produtos de Madeira S.A. é um investimento de US\$50 milhōes e sua capacidade anual de produção é de $75.000 \mathrm{~m}^{3}$ anuais, com cerca de $45 \%$ do volume destinado ao mercado internacional. Além disso, a empresa irá fornecer cavacos para a produção de celulose e de energia elétrica na serraria.

De outro lado, no que diz respeito a Cenibra, a própria forma pela qual foi constituída a empresa não deixa transparecer que exista algum interesse na integração para a frente, diversificando os produtos elaborados. A Cenibra é fruto de uma joint venture entre a Companhia Vale do Rio Doce (CVRD) e da Japan Brazil Paper and Pulp (JBP), na qual a CRVD detém $50,7 \%$ da empresa e o consórcio japonês, $49,3 \%$.

A Japan Brazil Paper and Pulp Resources Development Co., Ltd. - JBP foi criada em Tóquio, em 1971, com a participação das onze maiores empresas produtoras de papel e celulose do Japão, lideradas pela Oji Paper e pela Itochu, com a participação do governo japonês através do Overseas Economic Cooperation Fund (OECF). O objetivo inicial era importar cavacos de madeira para abastecer suas fábricas. Posteriormente, viabilizada a implantação da fábrica de celulose em Minas Gerais, assinou acordo com a CVRD para a criação da CENIBRA.

Por conta deste acordo, a JBP tem o direito de comprar $50 \%$ da capacidade nominal anual de produção e tem a opção de adquirir outros $20 \%$. Este acordo foi estendido por um período adicional de quinze anos em outubro de 1993. Por conta disso, a empresa é basicamente voltada para o mercado externo, e mais de $90 \%$ de sua produção é exportada.

Resta, finalmente, a Jari Celulose, originada da nacionalização da Cia. . Florestal Monte Dourado, de propriedade do empresário norte-americano Daniel Ludwig. O projeto Jari tinha como metas, na área florestal, a implantação de 200 mil 
ha de gmelina, eucalipto e pinus, os quais seriam utilizados na fabricação de celulose. Originalmente também estava nos planos a produção de 200.000 ton./ano de papel de imprensa (Mendonça Jorge, 1992).

O início de implantação do projeto, porém, foi marcado por uma série de dificuldades, algumas técnicas, outras políticas.

No âmbito técnico, a vulnerabilidade da gmelina a vários tipos de pragas tropicais, os problemas quanto ao direito de propriedade das terras, o problema social, fruto da aglomeração urbana formada à beira do Jari, e as dificuldades para a resolução da questão energética foram os maiores problemas.

No campo político o empreendimento era, inicialmente, considerado um caso de segurança nacional, mas a plantação de pinus na floresta Amazônica acabou por angariar críticas de ecologistas no mundo inteiro. Por outro lado, setores nacionalistas das Forças Armadas consideravam o projeto uma ameaça à soberania, dado o seu tamanho (Tavares, 1999).

Diante destes obstáculos, o então ministro do Planejamento, Delfim Netto, articulou a venda do empreendimento a um grupo de 23 empresários brasileiros.

Apesar da nacionalização, realizada no início de 1982, os problemas financeiros da empresa não foram resolvidos. No período de 1982 a 1996, a empresa apresentou lucro contábil somente no ano de 1994 e desde 1996, quando os controladores decidiram sair do negócio de celulose, a empresa interrompeu o fluxo de pagamentos das dívidas contraídas pela Jari Celulose.

Recentemente, no final de dezembro de 1999, a Saga Investimentos e Participações, holding para novos negócios do Grupo Orsa, assumiu o controle da empresa e deverá enfrentar um grande desafio. A empresa atravessa, no momento, uma situação bastante crítica em relação aos demais players. Seus custos de produção são elevados: o rendimento médio das florestas foi de 25,5 st/ha/ano em 1997, contra um valor superior a $40 \mathrm{st} / \mathrm{ha} / \mathrm{ano}$ de outras empresas. Os altos custos de energia foram agravados por um incêndio na unidade de geração de energia elétrica que provocou a paralisação da produção de celulose por seis meses em 1997. Além disso, em 1996, o 
grupo vendeu sua unidade produtora de cavacos de madeira para a Champion, comprometendo suas perspectivas de ampliação, num momento em que a escala de produção é um de seus principais gargalos. A situação é tal que a dívida total da empresa, cerca de US\$ 350 milhōes, é maior que seu Patrimônio Líquido, da ordem de aproximadamente US\$ 278 milhões.

Frente a todas estas dificuldades, e dado o fato de que agora ela pertence a um grupo que tem como principal atividade a produção de papel ondulado, não se espera, ao menos no curto prazo, que a Jari Celulose, rebatizada de "Complexo Jari", invista na produção de papel.

\subsection{Aspectos gerais da conduta da indústria brasileira de celulose}

De acordo com o que já foi dito anteriormente, a conduta das empresas depende da intensidade da rivalidade entre os concorrentes, a qual é uma conseqüência de fatores como o número de participantes, a dinâmica de crescimento na indústria, o grau de diferenciação do produto, a existência de barreiras à entrada ou à saída e a forma como se processa o aumento de capacidade na indústria (Porter, 1991).

Os fatores acima afetam aspectos da conduta, tais como estratégias de fusōes e aquisiçōes, política de preços, política de investimentos, pesquisa e desenvolvimento e propaganda.

Naturalmente, espera-se que quanto menor o número de participantes em um mercado, maior tende a ser a rivalidade existente entre eles, embora políticas de coordenação possam ser adotadas.

\section{FUSŌES E AQUISIÇŌES NA INDÚSTRIA}

No caso da celulose, a fusão de empresas obedece a uma tendência no mercado mundial, que será dominado, cada vez mais, por mega conglomerados ditando os preços de compra e venda do produto. A título de exemplo, a International 
Paper, após sua fusão com a Union, passou a ter um faturamento da ordem de US\$20 bilhões ao ano, enquanto a Aracruz fatura algo em torno de US\$500 milhões por ano.

Do ponto de vista das empresas brasileiras, está em discussão uma possível fusão da Aracruz, Cenibra e Bahia Sul, haja vista que as duas últimas possuem proprietários em comum. O projeto, conhecido como " $\mathrm{ABC}$ ", resultaria numa empresa com uma capacidade de produção da ordem de mais de 2,4 milhões de toneladas/ano de celulose, que representa um faturamento potencial de US\$1,4 bilhão, considerandose o preço da tonelada de celulose em janeiro de 2000.

Embora o BNDES já tenha se manifestado favorável à fusão, estando disposto, inclusive, a apoiar financeiramente 0 projeto, 0 processo enfrenta algumas dificuldades. Devido à sua capacidade de produção, a Aracruz exige controlar o projeto. Por outro lado, a Cia. Vale do Rio Doce (CVRD), que possui participações na Cenibra e Bahia Sul, teria a alternativa de buscar, primariamente, a fusão entre a Cenibra e a Bahia Sul, para então proceder à fusão com a Aracruz. A fusão conta com o apoio da Suzano, sócia da CVRD na Bahia Sul, no entanto, a CVRD enfrenta dificuldades em convencer os sócios japoneses da Cenibra a se associar à Bahia Sul, por conta das dificuldades financeiras desta última. Diante deste impasse, a CVRD manifestou sua intenção em comprar a parte japonesa da Cenibra.

\section{POLÍTICA DE PREÇOS}

A política de preços, por sua vez, também é afetada pelo número de participantes, bem como pela dinâmica de crescimento da indústria.

Como já assinalado por Porter (1991), quando o crescimento do mercado é lento, o processo de concorrência reduz-se à simples busca por uma parcela do mercado. Deste modo, nas fases de baixa demanda os preços são bastante pressionados, pois o aumento da concorrência no mercado internacional leva as empresas a tentar ganhar, ou simplesmente manter, parcelas do mercado utilizando-se, de forma intensa, da concorrência por intermédio dos preços.

No entanto, como adverte o BNDES (1993, p. 6), 
"(...) embora tendencialmente os custos de produção brasileiros sejam inferiores aos demais concorrentes, isto não é suficiente para garantir uma posição confortável em um período de forte excesso de oferta, como a vivenciada em 1991/93. Os estoques das empresas brasileiras se elevaram a níveis inesperados, demonstrando uma grande dificuldade de deslocar do mercado a produção de outras empresas."

Como agravante deste processo cíclico dos preços, há o fato de que as barreiras de saída na indústria são elevadas, pois a contraface da obtenção de grandes economias de escala é a existência de ativos bastante especializados, os quais apresentam valores baixos de liquidação. As empresas somente saem do mercado quando o seu grau de obsolescência tecnológica é tal que os custos de modernização superam o investimento em novas unidades.

Desta forma, surge um incentivo a mais para fusões e aquisições. Uma das principais razões para os processos de fusão e aquisição é o controle de capacidade e, conseqüente controle de preços. Uma grande companhia controla um grande número de unidades de produção e, desta forma, pode ter um controle maior sobre a oferta enquanto que as pequenas companhias podem, mais facilmente, decidir aumentar sua produção. Assim, a consolidação tem por objetivo reduzir o caráter cíclico da indústria, tornando o mercado mais previsível. De fato, acionistas e bancos de investimento estão preocupados pelo fato da indústria de papel como um todo não ter sido capaz de cobrir seu custo de capital ao longo da década passada, afastando os investidores. Neste sentido, fusões e aquisições contribuem para aumentar o valor acionário da empresa ou grupo controlador ${ }^{19}$ (Kenny, 1998).

Um número menor de participantes em um mercado aumenta a possibilidade de acordos para o estabelecimento de preços. A este respeito, é reveladora a afirmação do então presidente da Cenibra, a qual, mesmo tendo sido feita em 1985, é importante para determinar a conduta das empresas, quando do estabelecimento de preço: 
"(...) cada fabricante deve procurar racionalizar e economizar em quaisquer custos. $E$ a indústria nacional deve evitar uma concorrência inútil entre si nos vários mercados. Ao contrário (frisa) todos deverão procurar fórmulas cooperativas que promovam o lucro de cada um, e o lucro do setor a nível nacional" (Celulose e Papel, citado por Soto, 1992, p. 216).

No mercado internacional a situação não é diferente. No final da década de 70, quando o Brasil ampliava sua participação no mercado mundial de celulose, um grande produtor de papel e celulose sueco afirmava:

"As grandes quantidades de celulose brasileira trarão uma grande responsabilidade para as fábricas que deverão se introduzir no mercado, de tal maneira que não $\circ$ prejudiquem. Esperamos que os brasileiros sejam cuidadosos, quando entrarem na Europa, e isto depende das companhias. Se elas não tiverem cuidado, arruinarão o mercado para nós, para elas mesmas e para outras futuras fábricas brasileiras. Se nossos custos de produção são calculados de maneira normal, achamos que vocês, brasileiros, deveriam ter 0 mesmo interesse que temos em manter um preço adequado para celulose (...). Se o Brasil for para a Europa com preços baixos para sua celulose, tentando quebrar as regras do mercado, isto afetará todo o negócio de celulose" (Gazeta Mercantil, citado por Paladino, 1985, p. 249).

As afirmativas indicam que as empresas brasileiras seguem os preços mundiais da celulose (ditados pelo cartel NORSCAN), devido nõo só ao fato da produção brasileira ser pequena no mercado mundial ${ }^{20}$, mas também para "manter um preço adequado para celulose", de forma a garantir a rentabilidade do negócio de celulose ao longo do tempo. Ademais, a ausência, ou reduzida, diferenciação do produto, combinada com o fato de que a celulose representa um produto de primeira necessidade para o comprador, pode fazer com que este último seja bastante sensível em relação aos preços, de forma que uma guerra de preços deixaria todos os vendedores em pior situação.

\footnotetext{
${ }^{19}$ De acordo com Luiz Kaufmann (Aracruz), entre 1987 e 1996, os produtores de papel e celulose náo foram capazes de ganhar seu custo de capital, destruindo em torno de US\$ 27 bilhöes em valor acionário (Kenny, 1998).
} 
Além disso, observando-se o destino das exportaçōes das empresas brasileiras, pode-se também inferir que elas atuam de forma a "evitar uma concorrência inútil", procurando atuar em mercados diferentes. Tal como visto no quadro 4, a Aracruz exporta $39 \%$ de sua produção para a Europa e 37\% para a América do Norte. A Cenibra exporta mais de $70 \%$ de sua produção para o Japão (46\%) e Europa (28\%). A Bahia Sul tem na Ásia (34\%), Estados Unidos (34\%) e Europa (29\%) seus principais mercados. A VCP, por sua vez, atende principalmente a América Latina (27\%), o Oriente Médio (23\%) e a Europa (20\%). Finalmente, a Jari vende metade de sua produção para a Europa, enquanto que $23 \%$ da celulose que produz é destinada ao mercado interno.

É importante notar que, segundo dados da FAO, no período que vai de 1990 a 1998, a Europa foi responsável, em média, por, aproximadamente, 48\% das importações mundiais de celulose, enquanto que a América do Norte e a Ásia, responderam por, aproximadamente, $18 \%$ e $28 \%$, respectivamente, dessas importações. Desta forma, o fato de todas as empresas exportarem para a Europa não significa, necessariamente, que haja uma concorrência direta entre elas, devido ao grande mercado constituído por esse continente. Nos demais mercados, porém, fica clara a atuação de cada empresa em frentes diferentes.

\section{POLÍTICA DE INVESTIMENTOS}

Outro aspecto que envolve a conduta das empresas é a forma como ela implementa sua política de investimentos. Se, por um lado, a busca por economias de escala é cada vez maior, por conta da crescente concorrência no mercado mundial, e atua como uma barreira à entrada de novos players, por outro ela incentiva o processo de fusões e de estabelecimento de parcerias.

Assim, no ramo de celulose de mercado, as principais estratégias das empresas vão em direção ao aumento da capacidade produtiva, modernização industrial com crescente preocupação em minimizar os impactos ambientais da

20 O Brasil detinha, em 1998, cerca de apenas 3,49\% da capacidade de produçāo de celulose no mundo, segundo dados da PPI. Além disso, o preço de referência para a celulose no mundo é baseado no preço da celulose de fibra longa. 
produção, processos de reestruturação produtiva e reorganização societária por meio de fusões e incorporações, busca de produtos que propiciem um maior valor agregado e captação de recursos financeiros nos mercados internacionais.

Embora o país conte com empresas de grande porte, como a Aracruz e a CENIBRA, por exemplo, o tamanho médio das empresas no Brasil ainda é muito pequeno quando comparado aos demais países, conforme indicado no gráfico 8 .

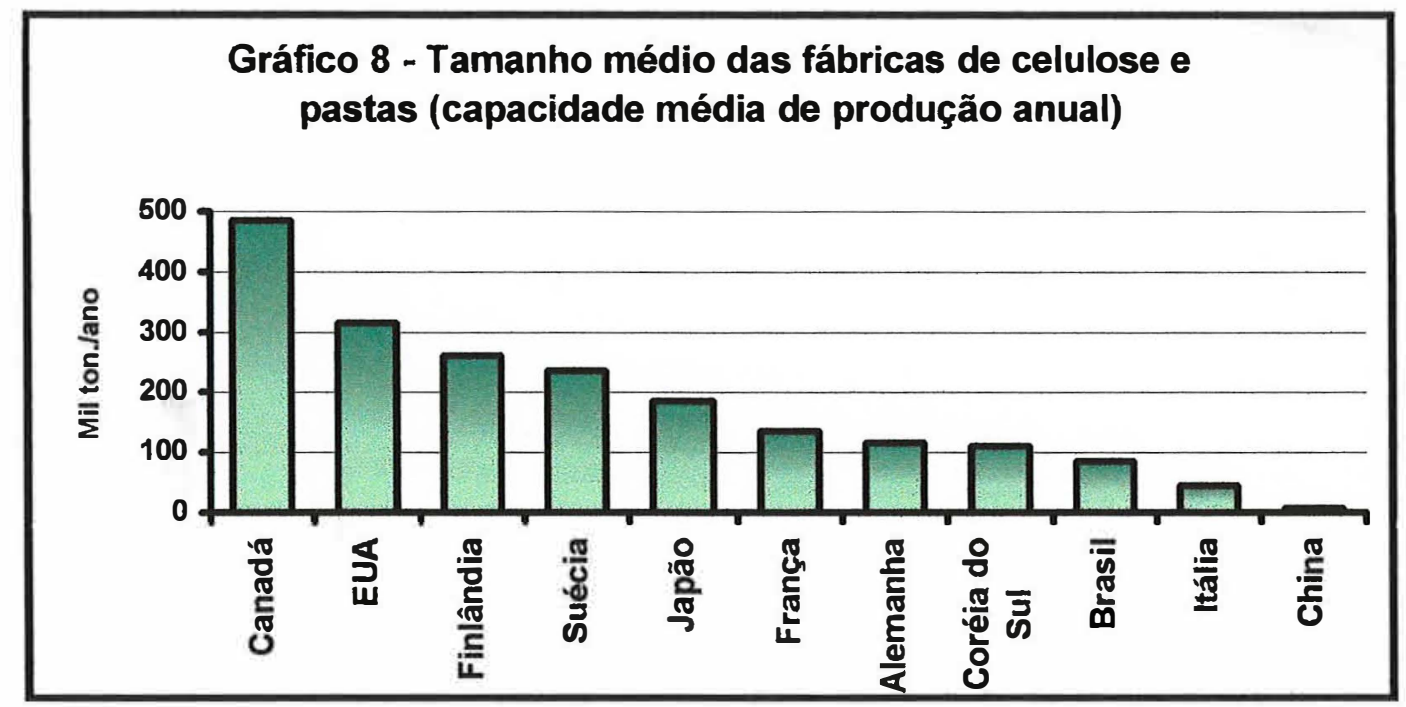

FONTE: Mattos \& Valença (1999)

A título de comparação, a fusão da sueca Stora com a finlandesa Enso, aprovada no final de 1998, representa uma capacidade de produção conjunta de 16 milhões de ton/ano de celulose, o que representa 10 milhões de toneladas a mais que toda a produção brasileira de 1997, de acordo com as estimativas da BRACELPA. Isto significa dizer que a Aracruz, maior fabricante brasileiro e detentora de $20 \%$ do mercado mundial de celulose de eucalipto, produz o equivalente a $8 \%$ da produção da Stora-Enso (D'Alessio, 1999)

Conseqüentemente, os investimentos no setor requerem um volume cada vez maior de recursos, buscando a ampliação da escala de produção e elevação do padrão ambiental, o qual vem se transformando num importante elemento de 
diferenciação do produto. Desta forma, a própria necessidade de investir grandes volumes de capital é uma barreira importante à entrada.

De acordo com dados do BNDES, admitindo-se uma taxa de crescimento da demanda mundial de celulose de eucalipto de 3,5\% a.a. nos próximos 8 anos, as exportaçōes brasileiras precisam aumentar de 792 mil toneladas apenas para manter 0 market share do país no comércio mundial (Macedo et al., 1998)

Não obstante, graças ao crescimento da demanda internacional e a conseqüente recuperação dos preços da celulose no mercado internacional, aliada à desvalorização do real, o setor passou a se preparar, nos últimos anos, para um novo ciclo de investimentos. O Quadro 4 mostra os principais projetos de investimentos do setor.

\section{Quadro 4 - Principais projetos de investimento em produção de celulose no Brasil - situação em 1999}

\begin{tabular}{|c|c|c|c|}
\hline Empresa & Projeto & $\begin{array}{l}\text { Investimento } \\
\text { (US\$) }\end{array}$ & Estágio \\
\hline Aracruz & $\begin{array}{l}\text { Aumento da capacidade de produção em } \\
700 \text { mil toneladas por ano }\end{array}$ & 700 milhöes & $\begin{array}{l}\text { Avançado - com previsão de término } \\
\text { em } 2000\end{array}$ \\
\hline VCP & $\begin{array}{l}\text { Aumento da capacidade de produção em } \\
400 \text { mil toneladas por ano }\end{array}$ & 500 milhões & $\begin{array}{l}\text { Avançado - com previsão de término } \\
\text { em } 2000\end{array}$ \\
\hline Cenibra & $\begin{array}{l}\text { Aumento da capacidade de produção em } \\
200 \text { mil toneladas por ano }\end{array}$ & 170 milhōes & $\begin{array}{l}\text { Avançado - com previsão de término } \\
\text { em } 2000\end{array}$ \\
\hline Veracel & $\begin{array}{l}\text { Construção de fábrica para produção de } \\
750 \text { mil toneladas por ano }\end{array}$ & 1,5 bilhão & Depende da entrada de novo sócio \\
\hline Riocell & $\begin{array}{l}\text { Aumento da capacidade instalada em } 70 \\
\text { mil toneladas e mudança na linha de } \\
\text { produção }\end{array}$ & 100 milhões & Depende de financiamento \\
\hline Bahia Sul & $\begin{array}{l}\text { Aumento da capacidade de produçáo entre } \\
500 \text { e } 750 \text { mil toneladas por ano }\end{array}$ & 800 milhöes & Fase inicial de estudos \\
\hline Celmar & $\begin{array}{l}\text { Construção de fábrica para produção de } \\
750 \text { mil toneladas por ano }\end{array}$ & 1,5 bilhão & Indefinido \\
\hline
\end{tabular}

FONTE: Adaptado de Grinbaum (1999)

Do quadro acima pode-se notar que, dada a procura por economias de escala cada vez maiores, causadas pelo processo de concorrência no mercado mundial, os aumentos de capacidade na indústria são feitos em grande escala. Isto se deve à 
tentativa de operar com custos cada vez menores e consequentemente com preços mais competitivos.

Não obstante, como já dito, o aumento de capacidade deve levar em conta as expectativas quanto a evolução futura da demanda e também a reação das empresas rivais, pois aumentos excessivos de oferta podem levar a indústria a enfrentar períodos de supercapacidade, com impacto nos preços. Dado que uma fábrica de celulose leva em média três anos para entrar em operação, os investimentos em aumento de capacidade sempre enfrentam riscos de eventuais mudanças nas condições futuras de mercado.

Por outro lado, as empresas procuram atuar de forma preemptiva, a fim de obter vantagens de ser o primeiro a se mover. Tais vantagens podem significar, por exemplo, a capacidade de capturar lucros extraordinários nas fases de alta de preços antes de seus competidores.

\section{POLITICA DE PESQUISA E DESENVOLVIMENTO}

Um outro aspecto importante, que define a conduta das empresas, é sua política de pesquisa e desenvolvimento. É importante frisar, como faz Paladino (1985), que não existe atualmente uma tecnologia alternativa para a produção de celulose e papel que seja capaz de assegurar uma rentabilidade competitiva para o investimento. A tecnologia disponível, portanto, exige que os produtores tenham acesso às suas próprias reservas florestais ou disponham de madeira a custos baixos, além de abundância de água e disponibilidade de energia a custos baixos.

Ainda de acordo com a autora, uma vez que esta tecnologia de produção foi desenvolvida pelos europeus e americanos, a primeira e principal forma pela qual ela foi transferida foi por meio da importação de máquinas e equipamentos destes países para as fábricas brasileiras de papel. Em 1935, porém, é instalada a primeira máquina de papel produzida no Brasil, feita pela Indústria Mecânica Cavallari, sob licença de fabricação da inglesa Millspaugh Ltd. Até a década de 50, quando outras fábricas de máquinas e equipamentos passaram a atuar no mercado, a Cavallari dominou a produção nacional. No entanto, quando outras fábricas entram no mercado, 
- fazem a partir de contratos de licença junto aos grandes produtores mundiais, ou através de subsidiárias destes, de forma que nunca existiu um processo nacional de geração de tecnologia para a produção de papel e celulose no país.

Em 1964, foi criada a Agência Especial de Financiamento Industrial (FINAME), cujo objetivo era financiar a compra de máquinas e equipamentos fabricados no país. Em seguida, na segunda metade da década de 60 , entrou em operação uma filial da alemã Voith S/A. A partir daí, as empresas nacionais não tiveram mais condições de acompanhar a evolução tecnológica no setor e passaram a prestar serviços de assistência técnica ou a reformar equipamentos.

Conforme apontado por um estudo do BNDES (1993), os primeiros grandes projetos na área de celulose, tais como a Borregaard (1968), a Aracruz (1974), a Cenibra (1975) e a Monte Dourado (1982), recorreram a máquinas e equipamentos estrangeiros. Especificamente no caso desta última, a fábrica inteira, sem ser desmontada, foi transportada do Japão até as margens do Rio Jari.

Daí em diante, movidas pelo crescimento do setor de papel e celulose no país, várias fábricas estrangeiras de equipamentos foram se instalando no país. De acordo com Higashi (1993, p. 94 -5),

"No país estão instaladas ou atuam as filiais das líderes mundiais (Voith S/A, Kamyr do Brasil, Beloit-Rauma Industrial Ltda., Sunds Defribator, Confab Industrial S/A, DFV - Automação e Robótica S/A e Unicontrol) de bens de capital de pasta e papel que fornecem aos usuários nacionais máquinas e equipamentos modernos e eficientes de padrão internacional. Mas, pela declarada insuficiência de escala de produção os preços dos equipamentos fabricados no Brasil são $35 \%$ a $45 \%$ superiores ao produzido no exterior. Ademais, os centros e laboratórios de pesquisa e desenvolvimento de tecnologias dessas filiais situam-se na matriz, geralmente no País de origem, de modo que os esforços de pesquisa e desenvolvimento da tecnologia incorporada nas máquinas e equipamentos, de pontos críticos para produção de papel e celulose, nunca foram e nem estão sendo desenvolvidos no País. Como conseqüência, no Brasil efetivamente está ausente o núcleo de progresso técnico o que significa o conhecimento do processo produtivo ao nível de 'know how', e ainda, o relacionamento das empresas de bens de capital com as empresas da indústria brasileira do papel é de caráter apenas mercantil." 
Desta forma, dada a pequena dimensão relativa da pesquisa tecnológica industrial dentro do país, no que se refere a bens de capital e processos de produção, os padrões técnicos da indústria brasileira acabam por ser definidos a partir daqueles gerados pelos grupos mundiais de ponta no setor. A indústria nacional de celulose apenas adapta a tecnologia e os equipamentos ao tipo de matéria-prima aqui utilizada.

É na área florestal, contudo, que o país mais avançou em termos de desenvolvimento tecnológico. Para Soto (1992, p. 180), "o processo inovativo crucial na evolução da indústria nacional de celulose e papel, foi a fabricação de papel integralmente feito com celulose de fibra curta originada do eucalipto. Esse é o único processo de inovação tecnológica registrado na indústria impulsionado pela iniciativa das empresas nacionais produtoras de celulose e papel" (grifo nosso).

Ainda de acordo com esse autor, (1992, p. 154), o processo inovativo constituiu em ter encontrado respostas tecnológicas em duas frentes principais: na parte agrícola, a questão era descobrir como obter uniformidade nas plantações de eucalipto através de trabalhos na área de reprodução vegetativa; na parte industrial, a intenção era obter tramas de fibra curta mais resistentes, por meio da realização de alterações importantes na técnica de refino (processo de desagregação das fibras da madeira).

É importante, contudo, perceber que os avanços na área florestal foram obtidos graças a um esforço conjunto da indústria e instituições de pesquisa, dentre as quais se destacaram o Instituto de Pesquisas Florestais (IPEF), a Empresa Brasileira de pesquisa Agropecuária (EMBRAPA), e o Centro Técnico de Celulose e Papel (CTCP), além de universidades tais como a USP-ESALQ, UFPR, UFV e UNICAMP (Mendonça Jorge, 1992).

\subsubsection{AlteraÇões na Conduta devido Às pressões ambientals}

Por outro lado, especificamente no que se refere às pressões ambientais, coube às empresas exportadoras de celulose, num primeiro momento, questionar os 
critérios de certificação, argumentando que eles significariam o estabelecimento de barreiras não-tarifárias às exportações para a $U^{21}$.

Alguns dos argumentos colocados pela indústria brasileira eram os seguintes:

i. a UE teria sido pressionada por ambientalistas e fabricantes de papel e celulose europeus que, com escassos recursos florestais, são forçados a utilizar mais a reciclagem que fibra virgem;

ii. os critérios técnicos acabariam por ser definidos com base em argumentos locais, condizentes com a realidade européia, em detrimento dos globais. A proximidade dos produtores domésticos e os custos financeiros de participação nas negociações para a elaboração dos esquemas de Eco-labelling aumentariam a possibilidade dos países europeus influírem em todo o processo, contemplando seus interesses ambientais, econômicos e comerciais (Castilho, 1994);

iii. a capacidade de absorção dos problemas ambientais de cada país varia de acordo com as suas características naturais, com o nível ou estágio de agressão ao meio ambiente e suas preferências sociais. $O$ estabelecimento de regras únicas não elimina estas diferenças, que são fontes de vantagens comparativas. Assim, se o meio ambiente for considerado um fator de produção, o resultado será uma alocação ineficiente dos recursos (Castilho, 1994);

iv. a exigência de que toda madeira seja originada de florestas sustentáveis é muito vaga para ser operacionalizada, pois ela não é baseada em parâmetros mensuráveis ${ }^{22}$. Ademais, nos parâmetros de

\footnotetext{
${ }^{21}$ É importante frisar que não se trata de uma reação apenas da indústria brasileira. A indústria de papel e papelão do Canadá, por exemplo, também vê o Eco-label como uma barreira não-tarifária contra seus produtos e afirma que os critérios para certificação favorecem os produtos fabricados pelos europeus.

${ }^{22}$ A definição de florestas sustentáveis utilizada pelo Eco-label da UE é baseada numa resoluçāo da Conferência Ministerial Sobre Proteção das Florestas Européias, realizada em Helsinki e que estabeleceu, de forma bastante geral, que manejo florestal sustentável é "o manejo e uso das florestas e recursos florestais (forestland) de modo a
} 
consumo de madeira, os critérios não valorizam apropriadamente 0 manejo sustentado de florestas, valorizando apenas a utilização de fibras recicladas (ABECEL, citado por Castilho, 1994);

v. os critérios desconsideram o balanço de emissões atmosféricas $\left(\mathrm{CO}_{2}\right.$ $\mathrm{x}_{2}$ ) promovido pelas florestas plantadas. Devido aos problemas de chuva ácida na Europa, os níveis aceitáveis de emissão de $\mathrm{SO}_{2}$ são exageradamente baixos para a concessão do Selo Verde. A redução de compostos orgânicos halogenados (AOX) é valorizada, mas não são consideradas na avaliação outras substâncias tóxicas, tais como aquelas responsáveis pelo branqueamento das fibras recicladas (ABECEL, citado por Castilho, 1994); e,

vi. O reaproveitamento do papel não deve ser considerado como redução da emissão de dejetos sólidos, pois esta medida desvaloriza os processos que utilizam fibra virgem. A contagem de "pontos" para - Selo Verde pelas empresas que usam papel reciclado consiste em uma vantagem para os produtores locais frente aos exportadores, em particular, os brasileiros, devido à baixa tradição de reciclagem no país, por fatores econômicos, geográficos e culturais, e ao elevado custo para os fabricantes brasileiros de se utilizarem de fibras recicladas frente a opção de fibras virgens a preços altamente competitivos (ABECEL, citado por Castilho, 1994).

Não obstante, seria falso afirmar que a conduta das empresas brasileiras produtoras de celulose, diante das pressões ambientais, tenha sido sempre apenas reativa. Ao contrário, embora criticando a forma pela qual os critérios foram estabelecidos, as empresas foram levadas, ao menos a partir da segunda metade da década de 80 , a adotar uma conduta pró-ativa. 
É preciso, então, separar a questão dos critérios pelos quais o desempenho ambiental é avaliado das pressões ambientais propriamente ditas, isto é, pode-se criticar a forma pela qual as pressões ambientais foram transformadas em padrões de conduta quantificáveis, mas é inegável a influência da conduta ambiental sobre a preferência do mercado consumidor.

A este respeito, Silva (1995, p. 54) afirma:

"ou a indústria se antecipa aos fatos fazendo da rotina de inovações uma criação contínua de soluções técnicas de respaldo público e privado, ou assiste a contração de mercado, restrições às escolhas dos consumidores, criação de novas barreiras à entrada e continuada queda de preços e lucratividade."

Na verdade, a questão ambiental, do ponto de vista da empresa, possui, basicamente, duas dimensões, uma mais restrita e outra mais ampla. De um ponto de vista mais restrito, a poluição é uma fonte de ineficiência, na medida em que aumenta os custos da empresa.

De acordo com Silva \& Bravo (1994, p. 122),

"A prevenção da poluição vem se destacando entre as empresas como a forma mais eficaz em termos de custo para alcançar a eficiência econômica e ambiental. Muitas delas identificam a poluição como um sinal de ineficiência, já que os resíduos representam desperdício de matérias-primas no processo de produção. Assim, elas são estimuladas a evitar a polvição porque, desta forma, estão poupando matérias-primas, cortando custos de tratamento e destinação final dos resíduos, melhorando a produtividade e, consequentemente, promovendo uma alocação mais eficiente dos seus recursos."

Outrossim, de uma perspectiva mais ampla, parece não haver dúvida que a questão ambiental, mais do que apenas uma questão de custos ou de uma resposta a exigências governamentais, é uma questão estratégica para as empresas. Sua capacidade de resposta às pressōes ambientais pode significar posiçōes na concorrência ou determinar, até mesmo, sua exclusão do mercado (Silva \& Bravo, 1994). Este fato pode ser ilustrado pela Tabela 13. 
Tabela 13 - Importância das preocupações ambientais na decisão de compra dos seus clientes

\begin{tabular}{lcccc}
\hline Situação & Aracruz & Cenibra & VCP & Riocell \\
\hline Determinantes & & $\mathrm{X}$ & $\mathrm{X}$ & \\
Muito importantes & $\mathrm{X}$ & & & $\mathrm{X}$ \\
Importantes & & & & \\
Irrelevantes & & & & \\
\hline FONTE: Dados de pesquisa & &
\end{tabular}

Por outro lado, cabe considerar também que o ambiente concorrencial onde as empresas atuam estabelece uma série de exigências, as quais são hierarquizadas de acordo com o objetivo primário de valorização do capital. Deste modo, quando o gasto ocasionado por investimentos impostos pelas demandas ambientais entram em conflito com este objetivo primário, as questões ambientais serão atendidas apenas em parte (Corazza, 1996).

A Tabela 14 mostra qual a importância das pressões ambientais em relação a outros fatores na definição do comportamento estratégico das empresas. Das quatro empresas que responderam ao questionário, três consideram a adaptação às pressōes ambientais muito importantes em relação aos demais fatores listados acima. Apenas a VCP não atribuiu o mesmo nível de atenção a este quesito. Isto é natural, pois, dada a importância das preocupaçōes ambientais dos maiores compradores da celulose brasileira, as empresas são levadas a dar grande ênfase à adaptação de seus processos de produção. 
Tabela 14 - Importância relativa das pressões ambientais no comportamento estratégico das empresas: 1 = irrelevante; 2 = pouco importante; 3 =importante; 4 = muito importante

\begin{tabular}{l|c|c|c|c}
\hline \multirow{2}{*}{ Fatores } & \multicolumn{4}{c}{ Notas } \\
\cline { 2 - 5 } & Aracruz & Cenibra & VCP & Riocell \\
\hline Busca de novos mercados & 4 & 4 & 4 & 4 \\
\hline Redução de custos & 4 & 4 & 4 & 4 \\
\hline Política cambial & 3 & 4 & 3 & 3 \\
\hline Financiamentos de longo prazo & 3 & 4 & 2 & 4 \\
\hline Taxas de juros interna & 3 & 4 & 2 & 3 \\
\hline Política tributária & 3 & 4 & 3 & 3 \\
\hline Adaptaçáo às pressöes ambientais & 4 & 4 & 3 & 4 \\
\hline
\end{tabular}

FONTE: Dados da pesquisa

Não obstante, deve-se notar que, em primeiro lugar, as empresas também dão grande importância à busca de novos mercados e à redução do custo, dado o fato da celulose constituir-se numa commodity. Em segundo lugar, seria de esperar também que as empresas dispensassem uma grande atenção à política cambial, uma vez que sua receita é diretamente dependente da taxa de câmbio. Finalmente, quanto aos quesitos taxa de juros interna, política tributária e financiamentos de longo prazo, todos eles atuam como fatores importantes na competitividade de qualquer setor, sendo mais importantes ainda naqueles onde 0 mercado relevante é o mercado mundial.

A questão mais importante, contudo, é de fato estabelecer qual é a conduta das empresas frente às pressōes ambientais e isto é feito observando-se a Tabela 15. 
Tabela 15 - Importância das estratégias para enfrentar a questão ambiental: 4 = muito grande; 3 = grande; 2 = pouca; 1 = nenhuma

\begin{tabular}{|c|c|c|c|c|}
\hline \multirow{2}{*}{ Estratégias } & \multicolumn{4}{|c|}{ Notas } \\
\hline & Aracruz & Cenibra & VCP & Riocell \\
\hline Desenvolvimento de novos produtos & 3 & 3 & 3 & 4 \\
\hline $\begin{array}{l}\text { Diferenciação do produto em relação aos } \\
\text { concorrentes }\end{array}$ & 3 & 4 & 4 & 4 \\
\hline $\begin{array}{l}\text { Adequação do produto aos vários } \\
\text { mercados }\end{array}$ & 4 & 4 & 4 & 3 \\
\hline $\begin{array}{l}\text { Associação da empresa, marca ou } \\
\text { produto com práticas ambientais } \\
\text { saudáveis }\end{array}$ & 4 & 4 & 4 & 4 \\
\hline Estabelecimento de preços competitivos & 3 & 4 & 2 & 3 \\
\hline $\begin{array}{l}\text { Ênfase em promoçōes (prazos e/ou } \\
\text { descontos) }\end{array}$ & 2 & 2 & 2 & 2 \\
\hline $\begin{array}{l}\text { Aumento do número de clientes } \\
\text { (geográficos) }\end{array}$ & 2 & 4 & 2 & 3 \\
\hline Busca de mercados menos exigentes & 2 & 2 & 1 & 2 \\
\hline $\begin{array}{l}\text { Busca de parcerias de longo prazo e por } \\
\text { produtos de maior valor agregado }\end{array}$ & 4 & - & - & - \\
\hline
\end{tabular}

A primeira característica que salta aos olhos é 0 fato de que 0 comportamento das empresas é bastante homogêneo. Frente às pressões ambientais, todas elas procuram, de forma bastante intensa, associar sua marca ou produto com práticas ambientais saudáveis. Nota-se também que não existe concorrência via preço. Embora as empresas se esforcem por estabelecer preços competitivos, é pouca a ênfase em prazos e/ou descontos. Há, outrossim, um esforço considerável para diferenciar o produto em relação aos concorrentes, bem como para desenvolver novos produtos, entendidos aqui, como novos processos de fabricação que dão à celulose características diferentes. Além disso, como seria natural, há um grande esforço para a adequação do produto aos vários mercados, pois as empresas não demonstram interesse em procurar mercados menos exigentes. Apenas a Cenibra demonstrou um grande interesse em aumentar o número de clientes em outras regiōes, embora a Riocell também considere importante esta procura. Assim, o que se pode inferir é que tanto a Aracruz quanto a 
VCP parecem ter um nicho de mercado nos países da Europa Ocidental, onde as exigências ambientais são maiores. No caso da Aracruz, a empresa ressaltou seu interesse na manutenção de parcerias de longo prazo.

\section{A CERTIFICAÇĀo}

Não obstante, na parte florestal, as pressões ambientais são dirigidas, basicamente, à utilização de métodos sustentáveis de manejo florestal. No entanto, a definição do que é "manejo florestal sustentável" é algo consideravelmente difícil, conforme atesta Roxo (1999, p. 2):

"[...] ○ manejo de florestas é uma operação [...] que não pode ser avaliada por um único indicador. As florestas apresentam variações significativas em todo o mundo, dependendo do clima, solo, história e cultura do país envolvido. O termo 'floresta' abrange vários ecossistemas diferentes, como a Floresta Amazônica, as florestas setentrionais ou os plantios de eucaliptos ou pinheiros. Existem, ainda, tantas variáveis envolvidas - econômicas, ambientais, sociais - que uma avaliação mais completa é necessária."

Novamente aqui, a conduta das empresas tem caminhado no sentido de adotar sistemas de certificação florestal com o propósito de informar os consumidores sobre a forma com que as florestas são manejadas.

Diante do fato de que, por exemplo, o Eco-Label da UE não apresenta critérios objetivos para definir "manejo florestal sustentável", as empresas vêm aderindo a dois esquemas de certificação florestal considerados como de validade global: o do Forest Stewardship Council (FSC) e a série ISO 14000 (no anexo B há mais detalhes sobre esses esquemas).

Um outro aspecto importante é que, durante os anos 90, vários países desenvolveram sistemas nacionais de manejo ambiental e selos ecológicos. Ante a proliferação destes standards e em uma fase de intensa competitividade comercial, tornava-se necessário criar regras de reconhecimento mútuo destas normas nacionais, tanto da gestão ambiental como do selo ambiental, para criar um padrão internacional 
por parte das empresas e regular o desenvolvimento comercial associado a critérios ambientais (Micheli, 2000).

O FSC é uma organização não-lucrativa fundada em 1993 e está sediada em Oaxaca, México. Ela surgiu a partir de insatisfação de vários grupos ambientais (World-wide Fund for Nature - WWF, Friends of Earth, Greenpeace, entre outros), liderados pelo WWF, com a falta de ação, no âmbito intergovernamental, no que se refere ao desenvolvimento de um esquema de certificação de madeira tropical. Assim, desde 1993, os grupos ambientais insistem na necessidade de certificação de florestas e da madeira pelo esquema FSC, o qual é apresentado pelas organizações ambientais como o único sistema de certificação aceitável para elas, embora estas organizações também contribuam para desenvolver sistemas nacionais ou regionais de certificação (Kiekens, 1997).

Para obter a certificação, o solicitante deverá sujeitar-se a dois tipos de inspeções: a inspeção inicial e, mais tarde, em caso de obtenção da certificação, inspeções anuais para manter a floresta sob certificação. Para a prova de que os padrões de manejo florestal foram alcançados, o movimento ambientalista e o FSC não confiam em governos e administrações florestais. Por conta disto, a certificação é operacionalizada por uma terceira parte, acreditada pelo FSC. Os certificadores acreditados realizam, sob solicitação e condicionadas a pagamento, as inspeções requeridas para a certificação (Kiekens, 1997).

É importante notar, porém, que no esquema FSC não existe um único padrão nacional de performance. Apenas a Suécia, o Reino Unido e a Bolívia têm padrões nacionais já aprovados. Existem, no entanto, trinta países para os quais estes padrões estão sendo desenvolvidos. Nos países onde não existem estes padrões, a certificação é baseada em padrões dos certificadores (Roxo, 1999). O desenvolvimento do padrão de certificação FSC pode ser observado na Tabela 16. 
Tabela 16 - Áreas florestais certificadas pelo FSC

\begin{tabular}{lccc}
\hline País & $\begin{array}{c}\text { Empresas / Proprietários } \\
\text { florestais }\end{array}$ & $\begin{array}{c}\text { Áreas certificadas } \\
\text { (ha) }\end{array}$ & $\begin{array}{c}\text { \% do total da área } \\
\text { certificada }\end{array}$ \\
\hline Suécia & 27 & 9.044 .695 & 51,68 \\
Polônia & 6 & 2.742 .786 & 15,67 \\
Estados Unidos & 55 & 1.595 .331 & 9,11 \\
Reino Unido & 17 & 862.265 & 4,93 \\
África do Sul & 9 & 779.621 & 4,45 \\
Brasil & 9 & 665.558 & 3,80 \\
Bolívia & 7 & 660.133 & 3,77 \\
Outros & 81 & 1.152 .178 & 6,58 \\
\hline TOTAL & 211 & $\mathbf{1 7 . 5 0 2 . 5 6 7}$ & 100,00 \\
\hline FONIE
\end{tabular}

FONTE: $h$ htp: $/ /$ www.fscoax.org

NOTA: Dados atualizados até 31 de março de 2000.

Especificamente no caso do Brasil, existe uma task-force da Associação Brasileira de Celulose e Papel (BRACELPA) que vem se reunindo periodicamente com integrantes do FSC Brasil para estabelecer critérios de certificação para as florestas plantadas. No setor de celulose e papel, a única empresa que é certificada pelo esquema FSC é a Klabin Fabricadora de Papel e Celulose $S / A^{23}$, a qual obteve o selo por intermédio da Rainforest Alliance.

Assim, como o FSC ainda não definiu um padrão de certificação para as florestas plantadas no Brasil, a indústria nacional de celulose vem procurando obter a certificação baseada na série ISO 14000.

Na verdade, como reação à iniciativa do FSC, a indústria canadense de papel e papelão, em associação com a indústria australiana, pressionou a International Standards Organization (ISO) para que esta desenvolvesse um padrão de manejo florestal (Kiekens, 1997).

\footnotetext{
${ }^{23}$ As outras empresas brasileiras certificadas no esquema FSC sāo: W. Faber-Castell; Duratex S.A. - Botucatu, Lençóis Paulistas, \& Agudos; Eucatex S.A. - Salto \& Botucatu e Buri; Floresteca Agroflorestal Ltda.; Flosul Industria e Comércio de Madeiras Ltda.; Mannesmann Florestal Lłda.; Madeireira Itacoatiara Ltda. e Plantar S.A.
} 
A ISO não caminhou nesta direção, ao invés disto, preferiu promover o uso da ISO 14001 relativa aos Sistemas de Gestão Ambiental (SGA's) no setor florestal. Os três princípios base da norma ISO 14001 são o respeito às leis e regulamentos, melhoramento contínuo e treinamento.

Conforme Roxo (1999, p. 6), "embora essas normas não se apliquem especificamente a operações florestais - elas lidam com processos de gestão, não com os tipos de operações -, têm sido bastante usadas por empresas florestais."

De acordo com Micheli (2000, p. 192-3),

"[a família de normas ISO 14000] se nutre da experiência da ISO 9000, pois baseiam-se no conceito de administração da qualidade: estão direcionadas aos requerimentos do cliente, ao controle do processo e à melhora contínua. Sem embargo, aumentam seu campo de interesse: os 'requerimentos do cliente' compreendem também as normas e leis ambientais, e a melhora contínua inclui tanto as expectativas do cliente como as metas autogeradas pela organização. "

A gestão ambiental envolve o conjunto dos aspectos gerenciais de uma organização necessários para desenvolver, alcançar, implementar e manter a política e os objetivos ambientais da organização. Para a ISO, um sistema de gestão ambiental é - conjunto formado pela estrutura organizacional, responsabilidades, práticas, procedimentos, processos e recursos necessários para implementar e manter $\circ$ gerenciamento ambiental (Nahuz, 1995).

Note-se que, diferentemente do esquema FSC, a norma ISO 14001 não requer qualquer outro padrão de performance, além do exigido pela legislação.

Os requisitos exigidos dizem respeito, basicamente, aos procedimentos que a empresa deve adotar para tornar explícita sua política ambiental, estabelecer os responsáveis por sua execução, bem como ○ responsável que irá assegurar que as normas sejam de fato cumpridas. Além disso, a organização deve manter procedimentos de comunicação interna e externa para assegurar que os efeitos ambientais de suas atividades sejam conhecidos e examinados e que toda legislação, regulamentos, códigos e outros requisitos sejam registrados e conhecidos. 
Da mesma forma que no esquema FSC, cabe a um certificador acreditado verificar se a organização está, de fato, implementando um SGA apropriado.

O processo de obtenção da certificação ISO 14001 exige um esforço considerável. No caso da Bahia Sul, por exemplo, "a mobilização para obter a certificação envolveu todos os níveis da empresa, clientes e fornecedores, num trabalho que durou 20 meses e consumiu US\$ 1 milhão. A empresa promoveu treinamentos que somaram 20 mil horas/homem e a normatização de 872 procedimentos internos (Silva, 1997, p. 15).

\section{A MUDANÇA DA PAUTA DE PRODUÇÃO}

Por outro lado, no que se refere ao processo de branqueamento da celulose, conforme já apontado, a descoberta, em meados da década de 80, de que o branqueamento com cloro produzia dioxinas colocou uma grande pressão sobre a indústria de celulose.

Como já explicado no capítulo 4, para solucionar esse problema surgiram duas alternativas: a substituição do cloro elementar pelo dióxido de cloro no branqueamento da celulose, gerando o processo ECF, ou o branqueamento com peróxido de hidrogênio, originando o processo TCF.

No entanto, pelo fato da celulose TCF ter maior custo de produção do que a celulose ECF e aquela não ser livre de críticas quanto a danos ambientais e nem ter diferencial de preço em relação à celulose ECF, as empresas de celulose de todo o mundo passaram a dar preferência à produção de ECF.

$\mathrm{Na}$ verdade, o debate sobre a conveniência ou não da adoção do branqueamento TCF pode ser visto como um embate entre os grupos ambientais, que raciocinam em termos globais, e as empresas que raciocinam com base em sua própria estratégia. Trata-se de um caso típico de um jogo não-cooperativo no qual uma empresa não adota o processo TCF simplesmente porque as demais não o farão.

Seguindo esta lógica, as empresas brasileiras também acabaram por optar pela produção de celulose ECF como alternativa ao branqueamento com gás 
cloro, buscando, desta forma, atender a mercados exigentes quanto a padrões ambientais (Tabela 17).

Tabela 17 - Evolução da distribuição percentual da produção segundo o processo de branqueamento utilizado

\begin{tabular}{c|c|c|c|c|c|c|c|c}
\hline \multirow{2}{*}{ Ano } & \multicolumn{4}{|c|}{ Aracruz } & \multicolumn{4}{c}{ Cenibra } \\
\cline { 2 - 10 } & Standard & ECF & TCF & ACF & standard & ECF & TCF & Outro \\
\hline 1995 & 39,46 & 52,66 & 7,88 & - & n.d. & n.d. & - & - \\
\hline 1996 & 46,00 & 46,00 & 8,00 & - & n.d. & n.d. & - & - \\
\hline 1997 & 33,00 & 56,00 & 11,00 & - & 47,95 & 52,05 & - & - \\
\hline 1998 & 33,00 & 55,00 & 12,00 & - & 48,98 & 51,02 & - & - \\
\hline 1999 & 28,12 & 61,28 & - & 10,60 & 48,69 & 51,31 & - & - \\
\hline \multirow{2}{*}{ Ano } & & \multicolumn{2}{|c|}{ VCP } & & & \multicolumn{2}{|c}{ Riocell } & \\
\cline { 2 - 11 } & Standard & ECF & TCF & VCF & standard & ECF & TCF & Outro \\
\hline 1995 & n.d. & n.d. & n.d. & n.d. & n.d. & n.d. & n.d. & n.d. \\
\hline 1996 & n.d. & n.d. & n.d. & n.d. & n.d. & n.d. & n.d. & n.d. \\
\hline 1997 & 80,79 & 19,21 & - & - & n.d. & n.d. & n.d. & n.d. \\
\hline 1998 & 35,07 & 61,37 & 3,11 & 0,45 & n.d. & n.d. & n.d. & n.d. \\
\hline 1999 & 36,18 & 56,66 & 5,53 & 1,63 & 72,00 & 28,00 & 0,00 & n.d. \\
\hline
\end{tabular}

FONTE: Dados de pesquisa

De outro lado, essas mesmas empresas produzem celulose standard (branqueada com cloro elementar) para atender o mercado interno ou a determinados clientes menos exigentes do ponto de vista ambiental, mas bastante sensíveis em relação a preço.

Fica claro, assim, que as empresas limitam-se a atender às exigências do mercado, porém, buscando, como é natural, colocar um produto com o menor custo possível, pois não há no mercado um diferencial de preços entre a celulose produzida pelos diversos processos de branqueamento. Note-se que, de acordo com a Cenibra, a produção de celulose ECF tem um custo adicional de $14 \%$ em relação à produção de celulose standard.

Outra questão importante, no que se refere à celulose standard, é que as empresas utilizam o cloro elementar em diferentes proporçōes na etapa de 
branqueamento. Enquanto a Riocell utiliza uma proporção de $10 \%$ de gás cloro e $90 \%$ de dióxido de cloro, a Cenibra trabalha numa proporção de $30 \%$ de gás cloro e $70 \%$ de dióxido.

Por outro lado, nos processos ecologicamente mais amigáveis, a questão fundamental é, como já dito no capítulo 4, o alto custo da celulose TCF e a ausência de um prêmio sobre o seu preço em relação ao preço de mercado da celulose ECF. Frente a isto, a VCP, por exemplo, produz uma celulose chamada de VCF. Trata-se de uma variante da celulose ECF com baixíssimo nível de AOX que teve sua produção iniciada em 1998. O mesmo acontece com a Aracruz que iniciou em 1999 a produção de celulose ACF para atender a mercados mais exigentes.

O mesmo se dá com as demais empresas. A Bahia Sul, que já está capacitada a adotar o processo ECF para toda a produção, trabalha atualmente com uma proporção média em tomo de $20 \%$ de celulose standard e $80 \%$ celulose ECF. A Jari, por sua vez, planeja iniciar o. processo de pré-deslignificação com oxigênio em meados de setembro de 2000. A partir daí, toda a produção poderá ser de celulose ECF. Atualmente metade da produção é standard e outra metade é ECF. A Riocell produz atualmente $70 \%$ de celulose standard e $30 \%$ de celulose ECF. A Cenibra produz $40 \%$ de celulose standard e $60 \%$ de celulose ECF. Na Tabela 18 está a capacidade de produção de celulose por tipo das empresas brasileiras exportadoras desse produto.

Tabela 18 - Capacidade de produção por tipo de celulose em 1999 (ton./ano)

\begin{tabular}{lcccc}
\hline Empresa & Standard & ECF & TCF & Outra* \\
\hline Aracruz & 355.000 & 774.000 & - & 134.000 \\
Cenibra & 393.092 & 387.799 & - & - \\
VCP & 213.000 & 284.000 & 24.000 & 24.000 \\
Riocell & 300.000 & 258.000 & - & - \\
\hline
\end{tabular}

FONTE: Dados da pesquisa

NOTA: No caso da Aracruz, o valor refere-se à produção de celulose ACF. No caso da VCP, à produção de celulose VCF.

Finalmente, no que se refere às tecnologias de final de circuito, a redução da carga de AOX pode se dar a partir da queima dos efluentes do processo de branqueamento, juntamente com os do estágio de polpação, numa caldeira de 
recuperação ou no tratamento biológico realizado com sistemas aeróbicos e anaeróbicos. Quanto ao material particulado, o controle é feito por intermédio de filtros e precipitadores eletrostáticos, além da possibilidade de se utilizar também lavadores úmidos de gases. No intuito de controlar as emissões de TRS ${ }^{24}$ utilizam-se sistemas de coleta e incineração dos gases e sistemas de monitoramento das fontes. Os efluentes líquidos são submetidos a até três etapas de tratamento, as quais objetivam remover o material sólido, o material orgânico e reduzir a cor do efluente e sua toxidez (Corazza, 1996).

Não obstante, é importante ressaltar que, de uma forma geral, as empresas estão muito mais preocupadas com os níveis de emissão de efluentes. Isto porque o comprador mais sensível às questöes ambientais exige, muito mais que um determinado padrão de branqueamento, um nível de emissão compatível com padrões mundiais. A Riocell, por exemplo, embora produza celulose standard classifica-se entre as empresas que não possuem um nível detectável de dioxinas.

\subsection{O desempenho da indústria brasileira exportadora de celulose}

O desempenho da indústria brasileira de celulose pode ser avaliado pela sua competitividade. Como foi ressaltado no capítulo 3, o critério mais adequado utiliza-se do conceito de "competitividade autêntica" ou "competitividade-eficiência" para analisar a indústria. Este conceito, ao contrário da competitividade-preço, é uma avaliação ex ante das condições de produção, refletindo, portanto, o potencial competitivo de um participante de determinado mercado, de sorte que a competitividade é vista como conseqüência da escolha adequada das técnicas de produção, capazes de alcançar, ou superar, os níveis de eficiência observados em um mercado particular.

Considerando todo o processo produtivo da celulose (da fase florestal à fase industrial) e as pressōes ambientais incidentes sobre as empresas pôdè-se verificar

\footnotetext{
${ }^{24}$ Compostos reduzidos de enxofre, responsáveis, como já assinalado, pelo mau cheiro nas redondezas das fábricas.
} 
que, no âmbito florestal, os padrões de referência internacionalmente aceitos para o manejo sustentável das florestas são o selo do Forest Stewardship Council (FSC) e os sistemas de gestão ambiental da norma ISO 14001. No entanto, como ainda não há no país um padrão de certificação definido para florestas plantadas no escopo do esquema FSC, as empresas brasileiras exportadoras de celulose vêm caminhando na direção da adequação à norma ISO.

Observando-se a Tabela 19, constata-se que apenas a VCP e a Jari ainda não possuem o certificado ISO 14001. No entanto, a VCP iniciará o processo de certificação a partir do segundo semestre de 2000 e a Jari estará recebendo em maio deste mesmo ano a visita do Bureau Veritas Quality International (BVQI) para a certificação da floresta, partindo, em seguida, para a adequação da parte industrial.

Tabela 19 - Empresas brasileiras exportadoras de celulose certificadas no padrão ISO 14001 e data de obtenção do certificado

\begin{tabular}{l|c}
\hline Empresa & Data de obtenção do certificado ISO \\
& $\mathbf{1 4 0 0 1}$ \\
\hline Aracruz & Out/1999 \\
Cenibra & Out/1997 \\
Bahia Sul & Set/1996 \\
Riocell & Jul/1999 \\
\hline
\end{tabular}

FONTE: Dados de pesquisa

A indústria brasileira de celulose utiliza apenas fibras de madeira plantada e tem alta produtividade em suas florestas. De acordo com Bacha \& Silva (1999), não só a área com matas plantadas no Brasil passou de 1,66 milhão de hectares em 1970 para 5,4 milhões em 1995 (sendo que a maior expansão ocorreu no período de 1970 a 1980), mas ocorreu também um significativo crescimento da produtividade desta atividade. A produtividade da eucaliptocultura cresceu $129 \%$ entre 1968 e 1988, passando de 17,5 para 40,0 estéreos/ha/ano ${ }^{25}$.

Para os autores,

${ }^{25}$ Conforme Antonangelo (1996), citado por Bacha \& Silva (1999, p. 30) 
"O aumento da produtividade da silvicultura brasileira foi devido, em grande parte, ao grande esforço nacional de pesquisa com essa atividade, em especial com as exóticas. Essas pesquisas foram viabilizadas, em parte, pelo PIFFR [Programa de Incentivos Fiscais ao Florestamento e Reflorestamento], pois 1\% dos recursos alocados como incentivos fiscais ao reflorestamento/florestamento foi utilizado para financiar a pesquisa silvicultural. Além disso, a diminuição do espaçamento entre as árvores também contribuiu, no período 1970 a 1985, para o incremento da produtividade" Bacha \& Silva (1999, p. 30).

A alta produtividade alcançada pelas florestas plantadas no Brasil diminui a necessidade de área plantada. Segundo dados da Jaakko Pöyry, a área requerida para uma fábrica de celulose com capacidade de produção de 500.000 ton./ano, seria de 80.000 ha no Brasil, 800.000 ha na Escandinávia e 1.600.000 ha em British Columbia (Canadá) ${ }^{26}$.

No Brasil, a inovação tecnológica na área florestal é bem mais ampla que a gerada na área industrial. A explicação para essa diferença pode ser obtida da análise de Higashi (1993). Para ele, as empresas foram fortemente condicionadas a adotar uma estratégia tecnológica ofensiva na área florestal, procurando obter alta produtividade, aliada à uniformidade nas florestas. Além disso, pesaram também a extinção dos incentivos fiscais no final da década de 80 e a necessidade de se desenvolver tecnologias específicas para a reforma de florestas. De outro lado, os elevados custos e os grandes riscos envolvidos fizeram com que a estratégia na área industrial fosse defensiva, de forma que as firmas líderes na fabricação de celulose e papel não possuem capacidade de inovação radical no que se refere a processos e produto, ficando, assim, dependentes das firmas de equipamentos industriais. $\mathrm{Na}$ área industrial, portanto, a maioria das empresas líderes possui somente capacidade de operação e adaptação das tecnologias industriais, gerando, assim, processos de inovação incremental.

Por outro lado, quanto aos principais parâmetros que medem o desempenho ambiental das plantas de celulose, pode-se verificar na Tabela 20 que,

${ }^{26}$ Citado em BNDES (s.d., p. 7) 
hoje, a indústria brasileira de celulose possui um desempenho extremamente competitivo em relação aos demais players no mercado mundial.

Tabela 20 - Desempenho ambiental típico das plantas de celulose química (kg/tsa)

\begin{tabular}{l|rcc|cc}
\hline \multirow{2}{*}{\multicolumn{1}{c|}{ Região }} & \multicolumn{3}{|c|}{ Efluentes líquidos } & \multicolumn{2}{c}{ Emissões atmosféricas } \\
\cline { 2 - 6 } & \multicolumn{1}{|c|}{$\mathrm{SS}$} & $\mathrm{DQO}$ & $\mathrm{AOX}$ & $\mathrm{MP}$ & $\mathrm{SO}_{2}$ \\
\hline África & $8-13$ & $45-90$ & $1,1-3,0$ & $8-15$ & $4-7$ \\
Ásia & $5-24$ & $70-150$ & $2,1-6,6$ & $2-23$ & $3-10$ \\
América Latina & $5-12$ & $50-76$ & $1,1-4,1$ & $9-21$ & $3-4$ \\
América do Norte & $3-6$ & $40-50$ & $2,1-4,3$ & $4-9$ & 2 \\
Europa & $4-13$ & $38-90$ & $0,5-4,4$ & $1-24$ & $1-7$ \\
Oceania & $4-6$ & $40-50$ & 2,1 & 9 & 2 \\
\hline Brasil & $3-8$ & $4-69$ & $0,1-0,6$ & $2-4$ & $0,3-3$ \\
\hline
\end{tabular}

FONTE: BNDES (s.d.)

NOTA: SS (sólidos em suspensão); DQO (demanda química de oxigênio); AOX (compostos orgânicos halogenados); (MP (material particulado); $\mathrm{SO}_{2}$ (dióxido de enxofre)

Não obstante, o custo financeiro envolvido no processo de adequação aos padrões ambientais mundiais é considerável. Segundo dados de Silva (1997), estima-se, inclusive no BNDES, que $10 \%$ do investimento total numa planta de celulose e papel vão para o meio ambiente. No caso da Aracruz, por exemplo, incluindo-se os investimentos na área florestal, o controle ambiental consumiu um valor próximo a US\$ 231 milhões, desde a implantação da fábrica, em 1967. Só o "Projeto F" (Free), implementado em 1992, envolveu um investimento de cerca de US\$ 100 milhões. A Riocell, por sua vez, já investiu mais de US\$ 41 milhōes no controle de emissões aéreas, efluentes hídricos, resíduos sólidos industriais e controle da qualidade ambiental. Só a construção de uma estação de tratamento de efluentes hídricos custou mais de US\$19 milhões. A Bahia Sul, de outro lado, já incorporou, desde a início das operações o que existe de mais moderno em tecnologia de controle ambiental. A empresa já investiu mais de US\$ 90 milhões na área ambiental (US\$ 70 milhōes na indústria e US\$20 milhões em florestas). 
Assim, o resultado de todo o esforço da indústria brasileira de celulose para alcançar a best practice internacional vem se refletindo de forma positiva no seu desempenho.

O gráfico 9 demonstra a evolução do market share do Brasil nas exportaçōes mundiais de celulose. Neste gráfico pode-se delimitar dois períodos nos quais a participação brasileira no mercado mundial de celulose cresceu. $O$ primeiro, que vai de 1977 a 1981, contempla a entrada em operação da Cenibra em 1977 e da Aracruz em 1978. O start up da Bahia Sul, em 1982, também contribui para manter a participação brasileira em torno de $4 \%$ do mercado mundial na primeira metade da década de 80.

O segundo salto da participação do Brasil nas exportaçōes mundiais de celulose se dá no período compreendido entre 1987 e 1993. Durante este período, entrou em operação a "fábrica B" da Aracruz Celulose, elevando a sua capacidade de produção para mais de um milhão de ton./ano de celulose de eucalipto. Neste segundo salto, são também importantes a duplicação da capacidade de produção da Cenibra, concluída no final de 1985, que elevou sua capacidade de produção para 700.000 ton./ano e a expansão da capacidade da Aracruz, no final de 1997, elevando sua capacidade de produção de 1.040 .000 para 1.240 .000 ton./ano, além do aumento, neste mesmo ano, da capacidade de produção da Votorantim (VCP), que passou de 550.000 para 800.000 ton./ano. Isto tudo fez com que o Brasil aumentasse em dois pontos percentuais sua participação no comércio mundial de celulose, passando a deter um market share de mais ou menos $6 \%$ das exportaçōes mundiais de celulose. 


\section{Gráfico 9 - Market share do Brasil na exportação de celulose no mundo}

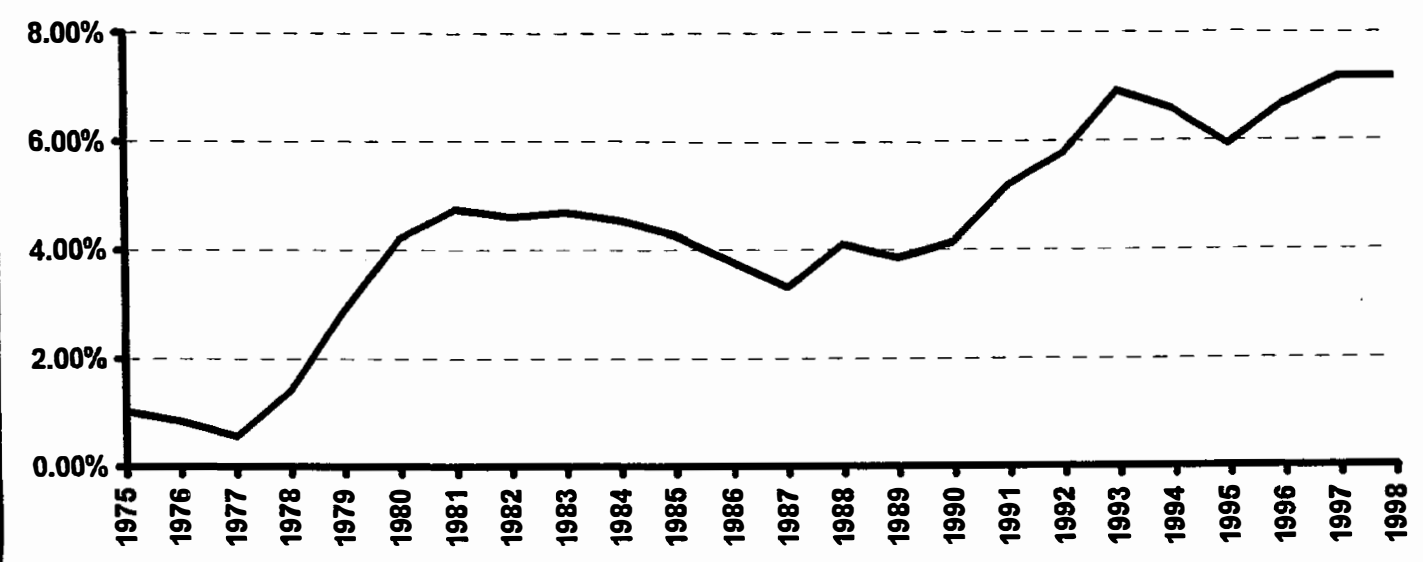

FONTE: http://www.fao.org

Note-se ainda que, quando se consideram as exportações para países específicos, o Brasil vem conseguindo não só manter seus mercados tradicionais, como, até mesmo, aumentar sua participação nos mesmos, conforme demonstra a Tabela 21. 


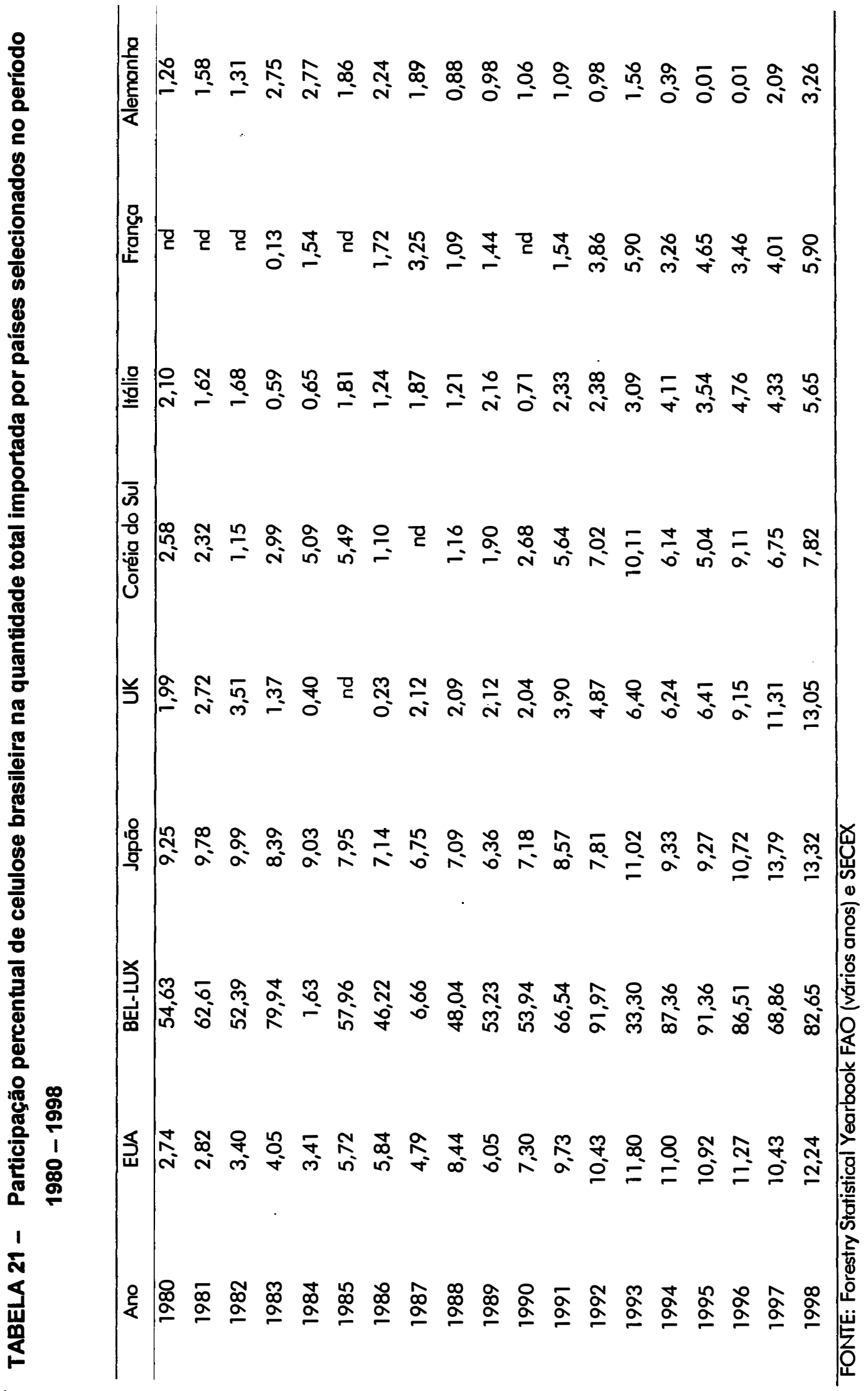


É importante, contudo, ressaltar que o desempenho relativo em termos de quantidade exportada não se reflete, necessariamente, sobre o lucro das empresas exportadoras.

Conforme mostra a tabela 4 do capítulo 5, embora o país seja o líder mundial na exportação de celulose de eucalipto, exportando mais que o dobro que $\circ$ segundo colocado, o preço deste tipo de celulose é fixado a partir do preço da celulose de fibra longa.

Assim, a pequena dimensão da produção brasileira em relação ao mundo e o processo de formação de preços a partir do cartel NORSCAN, fazem com que $\circ$ desempenho financeiro das empresas brasileiras seja fortemente influenciado não só pelo nível de preços internacional como também pela taxa de câmbio.

Em termos mais recentes, a década de 90 apresenta uma grande volatilidade dos preços da celulose. $\mathrm{O}$ Gráfico 10 mostra o comportamento dos preços praticados na Suécia e referem-se à celulose de fibra longa. No entanto, como já assinalado, a celulose de fibra curta costuma acompanhar, embora não de forma perfeita, as variações nos preços da celulose de fibra longa. 


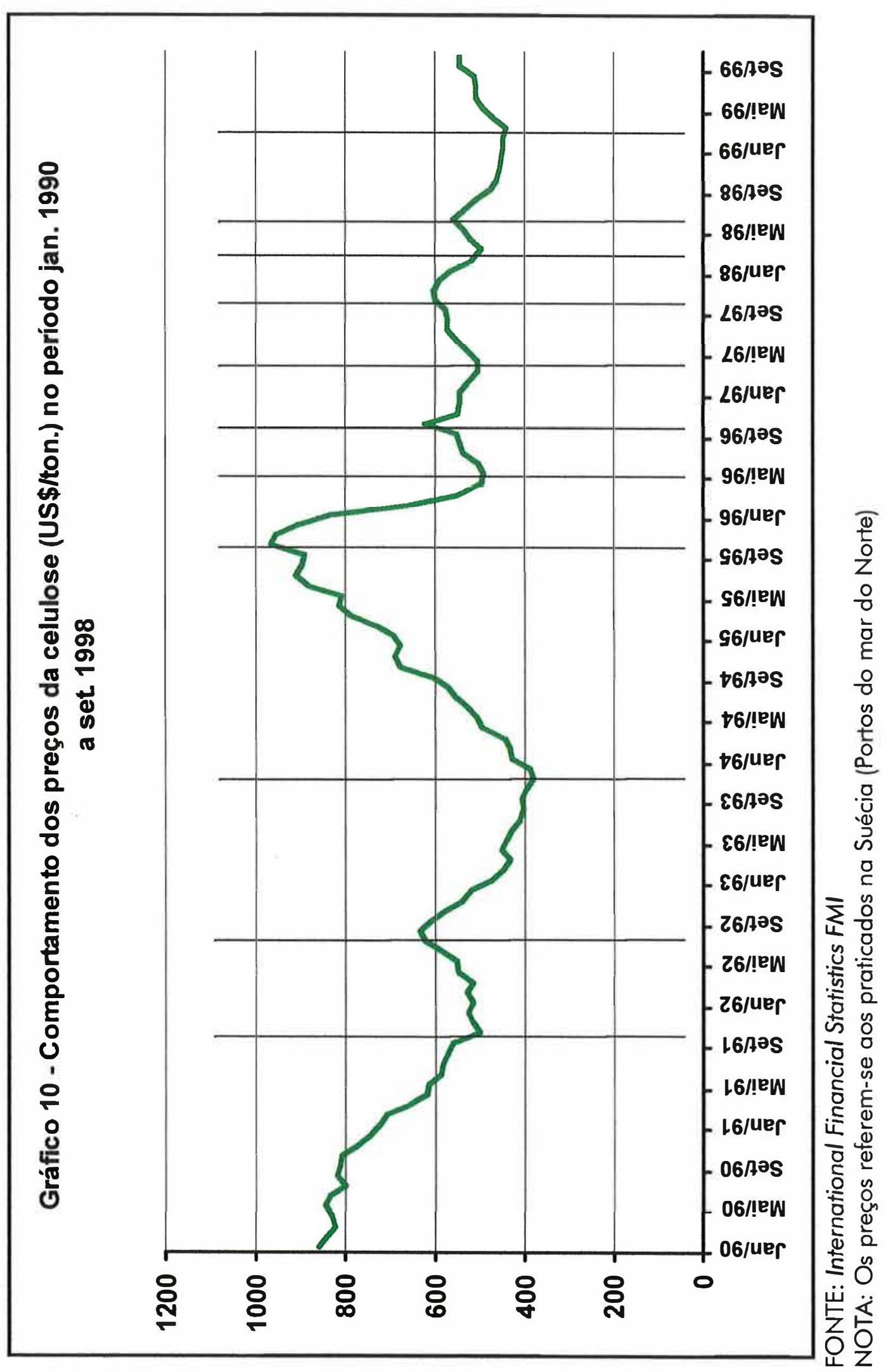


No que se refere aos preços da celulose de fibra curta, o início da década de 90 é marcado por uma queda dos preços internacionais que dura até o terceiro trimestre de 1991. Após um breve período de estabilidade, seguido de uma recuperação, os preços voltam a cair no último trimestre de 1992 até o final de 1993. Em termos gerais, o preço médio da celulose caiu de US\$ 818/t no último trimestre de 1989 para US\$ 319/t no mesmo período em 1993 (Bulhões, 1995).

O ano de 1994 marca o início de um período de recuperação. O reaquecimento das economias dos EUA e Europa - principais consumidores -, aliados à desestruturação da ex-URSS, fornecedora de madeira a baixos preços para os países escandinavos, e à diminuição dos abates de florestas nativas no Canadá, EUA e Escandinávia provocaram escassez da principal matéria-prima florestal para a fabricação da celulose. Além disso, a expansão dos mercados asiáticos também pressionou os preços (Bulhões, 1995).

A tendência de alta nas cotaçōes manteve-se quase durante todo o ano de 1995. A partir de novembro deste ano, porém, os preços internacionais de celulose passam a apresentar quedas acentuadas, reflexo do desaquecimento das economias dos países europeus e ao excesso de oferta de celulose no mercado internacional.

A partir do segundo trimestre de 1996, o mercado passa a experimentar um comportamento bastante errático dos preços de celulose. Por meio do Gráfico 10, pode-se observar que a partir deste ano a duração dos ciclos de preço vem diminuindo consideravelmente. Em anos recentes, observaram-se ciclos curtos, com duração inferior a doze meses, contrariando a experiência anterior dos produtores, acostumados com intervalos maiores entre um período de depressão de preços e outro.

No primeiro trimestre de 1997 o setor sentia ainda os efeitos da crise do período anterior e a situação só melhora no segundo trimestre. Os níveis dos estoques NORSCAN, próximos a 1,6 milhão de toneladas ${ }^{27}$ e a paralisação de algumas plantas

\footnotetext{
${ }^{27}$ Os estoques NORSCAN referem-se aos estoques da América do Norte e Escandinávia. O mercado mundial tem nestes estoques um parâmetro para os níveis de preços. O estoque "de equilíbrio" é de 1,5 milhão de toneladas. Estoques muito acima deste patamar levam a queda dos preços e estoques próximos a este nível levam a uma alta dos preços.
} 
industriais reduziram a oferta mundial de celulose, contribuindo para a sustentação dos preços. O aumento da demanda por parte dos EUA e Europa no segundo semestre deixou os produtores mais otimistas, no entanto, a crise asiática no último trimestre fez com que os preços fossem reduzidos (Gonçalves, 1998).

É importante notar que os países do Sudeste Asiático ${ }^{28}$ consomem $20 \%$ da celulose produzida no mundo e mesmo com a crescente oferta de celulose por parte da Indonésia, a região importou no ano de 1996 o equivalente a $22 \%$ de seu consumo. Por conta disso, o mercado de celulose foi o que mais imediato sentiu o impacto da crise asiática (Macedo \& Valença, 1998).

Para os produtores brasileiros, a crise trouxe aspectos positivos e negativos:

\begin{abstract}
"No curto prazo, o efeito da crise foi negativo, pressionando os preços no mercado de celulose. Com a desvalorização das moedas de países da Ásia, os produtores asiáticos passaram a ofertar celulose a preços mais baixos. Além disso, o consumo de celulose diminuiu devido à redução do nível de atividade econômica desses países, havendo um excesso de oferta que provocou queda dos preços." (Gonçalves, 1998, p. 67)
\end{abstract}

Por conta da crise asiática e da forte valorização do dólar americano o mercado de celulose, em 1998, apresentou um excesso de oferta de celulose. Neste ano fábricas foram fechadas nos EUA, Canadá e Europa, deslocando a oferta para a América Latina e Ásia, onde existem maiores vantagens comparativas. Por outro lado, os preços mantiveram-se em alta nos dois primeiros trimestres mas esta tendência foi interrompida novamente no segundo semestre. Neste ano, praticamente todas as empresas tiveram prejuízos. Além da queda dos preços internacionais e do desequilíbrio entre oferta e demanda, os produtores brasileiros enfrentaram um aumento nos custos financeiros por conta das altas taxas de juros internas.

O início de 1999 ainda apresentava preços deprimidos, mas os produtores nacionais beneficiaram-se da mudança na política cambial ocorrida em

${ }^{28}$ China, Japão, Coréia, Indonésia, Taiwan, Hong Kong, Malásia, Singapura e Tailândia. 
janeiro. Não bastasse a desvalorização do real, os preços internacionais voltaram a subir. Estima-se que, entre abril de 1998 e janeiro de 1999, cerca de aproximadamente 1,6 milhão de toneladas saíram do mercado mundial. Destas, cerca de 250 mil eram de celulose de mercado (Raposo, 1999).

As empresas voltaram a ter lucros, e começam a se preparar para mais uma rodada de grandes investimentos no setor. No final de 1999 as empresas estavam bastante otimistas com as perspectivas futuras. A desvalorização do real beneficiou as empresas brasileiras exportadoras de celulose na medida em que a receita de exportações é realizada em dólares e boa parte das despesas são feitas em reais. Ademais, uma série de grandes projetos na Ásia, particularmente das grandes plantas na Indonésia, foram suspensos ou cancelados, provocando um pequeno desequilíbrio entre oferta e demanda de celulose no mundo inteiro. Outro fator que também contribuiu para a recuperação de preços foi o desempenho vigoroso da economia norte-americana e a recuperação econômica da Ásia e Europa.

Os gráficos 11 a 14 mostram a relação entre a cotação da tonelada de celulose e o lucro de quatro empresas do setor. Note-se que, como dito acima, o desempenho de cada uma delas, em termos de resultados financeiros, é afetado diretamente pelas condições do mercado internacional de celulose. Quando os preços caem em reais (devido a variações no câmbio ou no preço internacional), os lucros tendem a cair e vice-versa. Mas essa relação não é necessariamente proporcional. É possível a certas empresas conviverem com preços em queda e manterem estabilidade de lucros, ou estes caírem menos que os preços. Para tanto, reorganizaçōes internas que implicam reduções de custo são necessárias e isto ocorreu nas empresas brasileiras a partir de 1994. 

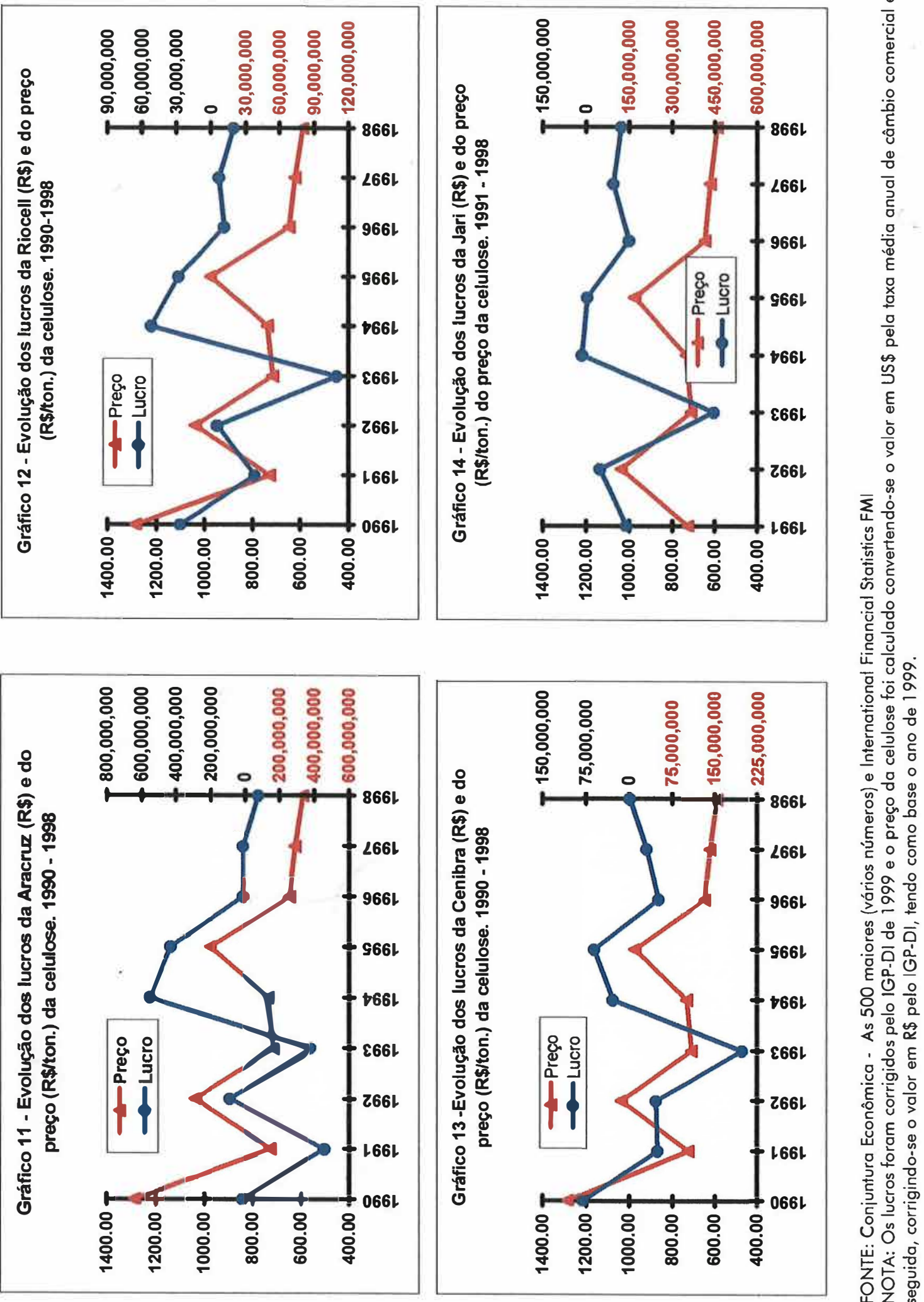


\section{CONCLUSÕES}

Esta dissertação analisou os impactos das pressōes ambientais sobre a conduta e o desempenho da indústria brasileira de celulose, com ênfase na questão da competitividade.

principal argumento apresentado é que as crescentes exigências ambientais impuseram um novo padrão competitivo, obrigando a indústria brasileira de celulose a se adequar a esta nova best practice para não perder espaço no mercado internacional.

Para fundamentar teoricamente as evidências do trabalho, utiliza-se o paradigma estrutura-conduta-desempenho $(E C D)$, associado às teorias de comércio internacional e à discussão de Porter sobre os fatores que condicionam as estratégias das empresas. Enfatizou-se também que a competitividade da indústria é dada por sua capacidade de adequação a uma best practice vigente no mercado internacional.

A metodologia adotada para a realização do trabalho baseou-se na análise tabular e gráfica de dados secundários e primários. Estes últimos oriundos da pesquisa de campo, realizada por intermédio de questionários.

O paradigma ECD estabelece cinco categorias principais de análise utilizadas para estudos no campo da organização industrial: as condições básicas de oferta e demanda, a estrutura do mercado, a conduta das empresas, o desempenho das empresas e as políticas públicas. No entanto, não há uma relação determinística, ao menos no longo prazo, entre estas categorias. 
Deste modo, o trabalho analisou como o surgimento do mercado ambiental influenciou as condiçōes básicas da demanda internacional de celulose. Observou-se que os consumidores passaram a valorizar a fibra reciclada como substituto para a fibra virgem e a modificar seus métodos de compra, os quais passaram a incorporar a exigência de determinados certificados ambientais. Tais certificados, por sua vez, são determinados pela política pública dos países compradores e estabelecem os critérios formais de performance que as empresas brasileiras produtoras de celulose devem alcançar.

Para a celulose, os parâmetros básicos que julgam sua qualidade ambiental estão ligados à utilização sustentável das florestas, ao conteúdo de fibras recicladas, ao uso de cloro no branqueamento, aos padrões de emissões químicas e biológicas e à presença final de compostos halogenados (AOX).

No intuito de clarificar a maneira pela qual a indústria brasileira de celulose respondeu a estas novas exigências ambientais, tratou-se de investigar o processo histórico de evolução desta indústria e sua inserção no comércio internacional de celulose. Num primeiro momento, mostrou-se que o desenvolvimento desta indústria foi, em grande parte, condicionado pelas políticas públicas que objetivaram, desde sempre, torná-la competitiva no mercado mundial. Desta forma, a política pública, levada a cabo em boa parte pelo Banco Nacional de Desenvolvimento Econômico e Social (BNDES) contribuiu, de maneira decisiva, para a criação e organizaçāo do setor exportador de celulose brasileiro, tal qual ele se apresenta hoje.

No início da década de 30 , a proibição da importação de máquinas para instalação de novas fábricas de papel, a criação de um fundo especial para socorrer as empresas em dificuldades e os incentivos fiscais para a importação de máquinas, acessórios e equipamentos necessários à produção de celulose, concedidos dentro do espírito de substituição de importações, dão início a uma série de medidas de política pública de apoio ao setor. Mais tarde, já na década de 50, surgiu, inserido no Plano de Metas, o primeiro programa governamental de investimentos específicos para papel e celulose. 
Na segunda metade da década de 60 , junto com a mudança na atuação do $B N D E$, que decidiu conceder prioridade aos projetos de implantação ou ampliação da capacidade produtiva de celulose e papel, o setor é beneficiado com o Decreto-Lei 5106/66 o qual contribuiu para uma grande expansão da área reflorestada nos anos seguintes. Em 1968, o BNDE estabeleceu que, a partir daquela data, os incentivos financeiros do Banco seriam direcionados para projetos que obedecessem a determinadas escalas mínimas de produção. Além disso, no início da década de 70, por conta de pressões do Banco, o Conselho de Desenvolvimento Industrial (CDI) aumentou a escala mínima exigida para que os projetos industriais de produção de celulose recebessem incentivos oficiais.

Em 1974, dentro da estratégia do II Programa Nacional de Desenvolvimento (PND), elaborou-se o I Programa Nacional de Celulose e Papel (PNPC) com o objetivo de alcançar a auto-suficiência em papel e celulose. Novamente aqui, o BNDE proporcionou uma série de vantagens para estas empresas. Assim, nas décadas de 60 e 70, ○ Estado influenciou diretamente nas condições básicas da oferta de celulose e na estrutura do setor.

Já na década de 80, apesar da crise econômica geral, iniciou-se um segundo ciclo de investimentos na modernização e ampliação da capacidade produtiva no setor, viabilizado, novamente, por linhas de financiamento de longo prazo do BNDES.

Os resultados da política pública orientada para a criação de uma indústria capaz de gerar excedentes exportáveis foram avaliados em seguida, considerando-se a evolução das exportações brasileiras de celulose. Além disso, foram estabelecidas as principais características, tanto dos maiores concorrentes do Brasil, como também dos maiores mercados consumidores de sua celulose. Evidenciou-se que os maiores concorrentes do país, no mercado de celulose de fibra curta, são os países da Península lbérica e que os grandes mercados consumidores da celulose brasileira são os EUA, Bélgica-Luxemburgo e Japão, os quais respondem, historicamente, por mais de $50 \%$ de nossas exportações. Não obstante, há outros mercados importantes, 
como Itália, França e Alemanha, que absorvem juntos algo em torno de $15 \%$ das exportações.

Conforme foi ressaltado, dada a pequena dimensão relativa da produção brasileira de celulose no mercado mundial e por conta de seu reduzido market share, este mercado teria plenas condiçōes de funcionar sem a presença do Brasil. Justamente por conta disso, a capacidade de resposta às pressōes ambientais por parte da indústria brasileira é extremamente importante, uma vez que o país não tem poder de mercado suficiente para impor padrōes de conduta.

Embora ainda existam mercados para os quais a questão ambiental não é relevante, como é o caso do Oriente Médio, a pesquisa de campo demonstrou que as empresas brasileiras dão uma ênfase muito maior à questão da adequação do produto aos vários mercados do que à busca de mercados menos exigentes, até por que os maiores mercados (europeu, norte-americano e asiático) são, em maior ou menor grau, os que apresentam maiores exigências ambientais.

Assim, quanto à conduta das empresas, considerou-se, primeiramente, a questão do estabelecimento de preços da celulose no mercado internacional, mostrando que, dada a ausência, ou reduzida diferenciação do produto, uma guerra de preços no mercado internacional acabaria por deixar todos os vendedores em pior situação. Assim, o preço da celulose brasileira tende a seguir os preços estabelecidos pelo cartel NORSCAN para a celulose de fibra longa, guardadas as diferenças de qualidade. Mostrou-se também que, por conta desta situação, as empresas tendem a buscar economias de escala cada vez maiores, por intermédio de aumentos de capacidade, atendendo-se, por meio de duas estratégias a um mesmo objetivo: redução de custos, com capacidades de produção cada vez maiores, e controle de oferta no mercado mundial.

Além disso, ressaltou-se também a questão da capacidade de inovação da indústria brasileira de celulose, mostrando-se que na área florestal existe potencial para inovações mais profundas, haja vista a criação de um processo de produção de papel totalmente feito com celulose de fibra curta de eucalipto, mas na área industrial existe apenas capacidade para inovaçōes adaptativas, pois a pesquisa e 
desenvolvimento da tecnologia presente nas máquinas e equipamentos é desenvolvida fora do país por empresas multinacionais.

Finalmente, quanto ao desempenho da indústria brasileira exportadora de celulose, o trabalho demonstrou que, na parte florestal, o mercado internacional de celulose considera como a melhor prática a certificação pelo esquema FSC ou pela norma ISO 14001. Na parte industrial, a melhor prática é medida em termos da substituição do cloro elementar no processo de branqueamento e em termos de indicadores relativos aos efluentes líquidos (sólidos em suspensão, demanda química de oxigênio e AOX) e emissōes atmosféricas (material particulado e dióxido de enxofre).

Além disso, o trabalho assumiu que a competitividade no mercado internacional é uma conseqüência da capacidade do país em alcançar ou suplantar a best practice vigente no mercado em que ela atua. Assim, o desempenho exportador é fruto da capacidade das empresas brasileiras exportadoras de celulose em atender às exigências do mercado mundial.

Portanto, foi a adequação das empresas brasileiras a estes padrōes que tornou possível ao país manter sua competitividade no mercado e lograr, até mesmo, aumentar seu market share nas regiōes onde as preocupaçóes ambientais são maiores.

Por fim, cabe salientar as limitações do trabalho. Em primeiro lugar, não se faz uso de técnicas estatísticas mais complexas para estudar relações eventualmente postuladas entre determinadas variáveis. Isto, contudo, além de transcender o escopo desta dissertação, não afeta as conclusōes básicas obtidas. Em segundo lugar, pode-se argumentar que 0 preenchimento de questionários tem sempre um componente subjetivo, de sorte que a mesma questão poderia ser respondida de forma diversa por outra pessoa dentro da mesma empresa. Contudo, novamente aqui, as respostas fornecidas pelos questionários não alteram os resultados básicos obtidos da análise de dados secundários. Além disso, não se pode esquecer que a metodologia aqui adotada tem apresentado resultados bastante satisfatórios para o emprego do paradigma ECD e é impossível acreditar que exista uma metodologia alternativa, capaz de eliminar todos problemas inerentes à investigação científica. 
Neste aspecto, portanto, fica a proposta para a realização de futuros estudos que avancem na questão do desempenho exportador da indústria brasileira de celulose, adotando um enfoque mais quantitativo ao problema, buscando avaliar econometricamente as variáveis que explicam as variaçōes nas exportaçōes brasileiras de celulose. 


\section{ANEXO A}

\section{QUESTIONÁRIO ENVIADO ÀS EMPRESAS BRASILEIRAS EXPORTADORAS DE CELULOSE}

AS INFORMAÇÕES COLHIDAS PELO PRESENTE QUESTIONÁRIO SERÃO UTILIZADAS APENAS PARA FINS DE PESQUISA.

- Por fovor responda o questionário de forma completa o mais rápido possível;

- Caso alguma questão não esteja clara, deixe em branco;

- Após respondido, favor enviar no envelope anexo ou pelo fax 19434 - 5186 aos cuidados de Emerson M. Hilgemberg (mestrado).

1. Nome da empresa:

2. Qual a capacidade de produção por tipo de celulose em 1999? (mil ton./ano)

\begin{tabular}{|l|l|}
\hline \multicolumn{1}{|c|}{ Tipo de celulose } & Capacidade de produção \\
\hline Standard & \\
\hline ECF & \\
\hline TCF & \\
\hline Outras (especificar) & \\
& \\
\hline
\end{tabular}

3. Quais têm sido, em ordem crescente, os cinco maiores países importadores de celulose da empresa nos últimos cinco anos?

1 .

2.

3.

4.

5. 
4. Considerando-se os últimos cinco anos, qual a porcentagem aproximada da produção total que é realizada pelos seguintes processos?

\begin{tabular}{|c|l|l|l|l|}
\hline ANO & standard & ECF & TCF & outras \\
\hline 1995 & & & & \\
\hline 1996 & & & & \\
\hline 1997 & & & & \\
\hline 1998 & & & & \\
\hline 1999 & & & & \\
\hline
\end{tabular}

5. Por favor, indique, em ordem crescente, quais são as cinco empresas com as quais há uma concorrência mais direta no negócio de celulose de mercado mundial.

\begin{tabular}{|l|l|}
\hline \multicolumn{1}{|c|}{ Empresa } & \multicolumn{1}{c|}{ Nacionalidade } \\
\hline 1. & \\
\hline 2. & \\
\hline 3. & \\
\hline 4. & \\
\hline 5. & \\
\hline
\end{tabular}

6. Marque com um $X$ a resposta que melhor indica como sua empresa se situa, em relação aos seus concorrentes, quanto ao nível dos padrões ambientais exigidos por seus consumidores?

(a) Plenamente satisfatório

(b) Satisfatório

(c) Deficiente

(d) Muito deficiente

7. Como a empresa percebe a importância de preocupações ambientais na decisão de compra de seus consumidores?

(a) Determinantes

(b) Muito importantes

(c) Importantes

(d) Irrelevantes 
8. Atribua notas, de 1 a 4 , aos seguintes fatores que motivam o comportamento estratégico de sua empresa

1 = irrelevante; 2 = pouco importante; 3 =importante; 4 = muito importante

\begin{tabular}{|l|l|}
\hline \multicolumn{1}{|c|}{ Fatores } & NOTA \\
\hline a. Busca de novos mercados & \\
\hline b. Redução de custos & \\
\hline c. Política cambial & \\
\hline d. $\quad$ Financiamentos de longo prazo & \\
\hline e. $\quad$ Taxas de juros interna & \\
\hline f. Política tributária & \\
\hline g. Adaptação às pressōes ambientais & \\
\hline h. Outro (especificar) & \\
\hline i. Outro (especificar) & \\
\hline i. Outro (especificar) & \\
\hline
\end{tabular}

9. Frente às pressōes ambientais, atribua uma nota, de acordo com a escala abaixo, para a ênfase da empresa nas seguintes estratégias:

$$
4 \text { = muito grande; } 3 \text { = grande; } 2 \text { = pouca; } 1=\text { nenhuma }
$$

\begin{tabular}{|l|l|}
\hline \multicolumn{1}{|c|}{ Estratégias } & NOTA \\
\hline Desenvolvimento de novos produtos & \\
\hline Diferenciação do produto em relaçāo aos concorrentes & \\
\hline Adequação do produto aos vários mercados & \\
\hline Associação da empresa, marca ou produto com práticas ambientais saudáveis & \\
\hline Estabelecimento de preços competitivos & \\
\hline Ênfase em promoçōes (prazos e/ou descontos) & \\
\hline Aumento do número de clientes (geográficos) & \\
\hline Busca de mercados menos exigentes & \\
\hline Outras (especificar) & \\
& \\
\hline
\end{tabular}


10. Outros esclarecimentos que julgar relevantes:

\section{SUAS INFORMAÇÕES FORAM MUITO ÚTEIS PARA A REALIZAÇÃO DESTA PESQUISA. \\ MUITO OBRIGADO.}




\section{ANEXO B \\ SISTEMAS DE CERTIFICAÇÃO FLORESTAL: FSC E ISO 14001}

\section{O SISTEMA FSC}

O esquema FSC se apoia: (1) numa série de dez princípios $^{29}$ sobre manejo florestal e em critérios aprovados, por votação, pelos membros da organização, (2) na definição de padrōes de performance no nível de cada país, (3) na inspeção independente de florestas e, (4) em um selo que pode ser usado por certos produtos, sujeito a um pagamento e a um controle independente da cadeia de comercialização (marketing chain).

Segundo o FSC (FSC, 1999), seus princípios dizem respeito, basicamente, a:

1. Obediência às leis do país e aos princípios do FSC;

2. Evidências claras do direito ao uso da terra (título de propriedade, contratos de arrendamento, etc);

3. Respeito e reconhecimento dos direitos das populações indígenas (direitos de propriedade, uso e manejo de suas terras e recursos), de sorte que o manejo florestal não ameace, direta ou indiretamente, os recursos ou direitos de posse das populações indígenas;

4. Oportunidades de emprego, treinamento e outros serviços para as comunidades das áreas que estejam dentro ou sejam adjacentes à área de manejo florestal, condições que alcancem ou excedam as leis e regulamentos de saúde e segurança dos empregados e de suas famílias e respeito aos direitos de organização e negociação dos trabalhadores;

\footnotetext{
${ }^{29}$ Kiekens $(1997$, p. 3) ressalta o fato de que estes princípios näo refletem qualquer acordo internacional em termos de manejo florestal sustentóvel e constituem, na sua maioria, em um tipo de consenso no nível do movimento ambiental
} 
5. Encorajamento do uso eficiente dos múltiplos produtos e serviços florestais para assegurar viabilidade econômica e uma ampla gama de benefícios sociais e ambientais;

6. Conservação da biodiversidade e seus valores associados, recursos hídricos, solos e ecossistemas, mantendo-se as funções ecológicas e a integridade da floresta;

7. Elaboração, implementação e atualização constante de um plano de manejo florestal;

8. Monitoramento apropriado, respeitando a escala e intensidade do manejo florestal, com o objetivo de verificar as condições da floresta, rendimento dos produtos florestais, cadeia de custódia ${ }^{30}$, atividades de manejo e seus impactos sociais e ambientais.;

9. Manutenção de "florestas de alto valor de conservação", definidas como tal aquelas que contêm, do ponto de vista global, regional ou nacional, (i) significantes concentrações de biodiversidade, (ii) grandes florestas contidas, ou que contenham, a unidade de manejo, onde populações viáveis da maioria, ou de todas, as espécies naturais existam em padrōes naturais de distribuição e abundância; áreas florestais que estejam em, ou contenham, ecossistemas ameaçados ou em perigo; áreas florestais que forneçam serviços básicos da natureza em situaçōes críticas (proteção a bacias hidrográficas, controle de erosão); áreas florestais fundamentais para satisfazer as necessidades básicas das comunidades locais e/ou críticas para a identidade cultural (áreas de significado cultural, ecológico, religioso), estabelecidas em cooperação com estas comunidades;

\footnotetext{
${ }^{30}$ Segundo o FSC, "cadeia de custódia" é o canal pelo qual os produtos são distribuídos da sua origem na floresta
} para seu uso final. 
10. Nas áreas de florestas que resultem de atividades humanas (plantations) devem ser respeitados os princípios anteriores, bem como os seguintes itens:

10.1. Os objetivos do manejo, incluindo a conservação da floresta e objetivos de restauração, devem ser explicitamente colocados no plano de manejo, e claramente demonstrados na sua implementação;

10.2. O desenho e layout da área plantada deve promover a proteção, restauração e conservação das florestas naturais e não aumentar as pressões sobre elas. Devem ser usados no layout da área plantada corredores de vida selvagem (wildlife corridors), zonas de proteção de margens de rios e mosaicos com plantas de diferentes idades e períodos de rotação. A escala e layout dos blocos plantados deve ser consistente com os padrões encontrados na paisagem natural;

10.3. A diversidade na composição das plantações é preferível;

10.4. A seleção de espécies para o plantio deve ser baseada na sua sustentabilidade e a sua adequação aos objetivos de manejo. As espécies exóticas só devem ser utilizadas quando sua performance é maior que a das espécies nativas, e deve ser cuidadosamente monitorada para detectar mortalidade incomum, doenças ou pragas de insetos e impactos ecológicos adversos;

10.5. Uma proporção do total da área de manejo florestal, em escala apropriada ao tamanho da plantação, deverá ser manejada de forma a restaurar a cobertura florestal natural;

10.6. Medidas devem ser tomadas para manter ou melhorar a estrutura do solo, fertilidade e atividade biológica; 
10.7. Medidas devem ser tomadas para prevenir e minimizar a ocorrência de pestes, doenças, fogo e introduções invasivas de plantas. $O$ manejo da plantação deve fazer todos os esforços para evitar a utilização de pesticidas e fertilizantes químicos, incluindo seu uso em viveiros;

10.8. O monitoramento das plantações deve incluir avaliações regulares dos impactos ecológicos e sociais, tanto on-site quanto off-site.

Por outro lado, o próprio FSC afirma que ele e as organizações certificadoras por ele acreditadas não irão insistir na perfeição quanto a satisfação dos princípios e critérios acima estabelecidos. Contudo, faltas mais graves em qualquer dos princípios individuais irão normalmente desqualificar um candidato para a certificação, ou levarão à perda da certificação (FSC, 1999).

\section{A ISO 14001}

Conforme já visto, uma das diferenças fundamentais entre o esquema FSC e a norma ISO 14001 é o fato desta última não requerer qualquer outro padrão de performance, além do exigido pela legislação.

Cabe à empresa, no entanto, estabelecer um Sistema de Gestão Ambiental (SGA), o qual envolve o conjunto dos aspectos gerenciais de uma organização necessários para desenvolver, alcançar, implementar e manter a política e os objetivos ambientais da organização. Para a ISO, um sistema de gestão ambiental é - conjunto formado pela estrutura organizacional, responsabilidades, práticas, procedimentos, processos e recursos necessários para implementar e manter o gerenciamento ambiental (Nahuz, 1995).

Adicionalmente a organização deve estabelecer e manter procedimentos que especifiquem seus objetivos ambientais e metas derivadas destes objetivos. Aqui também é necessário documentar o plano de ação criado para permitir $\bigcirc$ alcance das metas fixadas, bem como a definição das responsabilidades de gerenciamento do 
mesmo. O importante definir as responsabilidades de gerenciamento no intuito de assegurar-se de que todas as atividades de controle, verificação e testes sejam feitas de forma coordenada e efetiva e registradas de modo que seja possível demonstrar a conformidade com os requisitos do sistema de gerenciamento ambiental e verificar a extensão em que os objetivos e metas planejados foram de fato atingidos.

Finalmente, cabe à organização estabelecer e manter procedimentos para execuçâo de auditorias, conduzidas dentro de um sistema de gerenciamento estruturado e concebidas dentro de um sistema gerencial integrado e direcionado para atingir efeitos ambientais significativos, sempre dentro da filosofia de melhoramento contínuo (Figura 4).

Figura 4 - Melhoramento continuo sob a ISO 14001

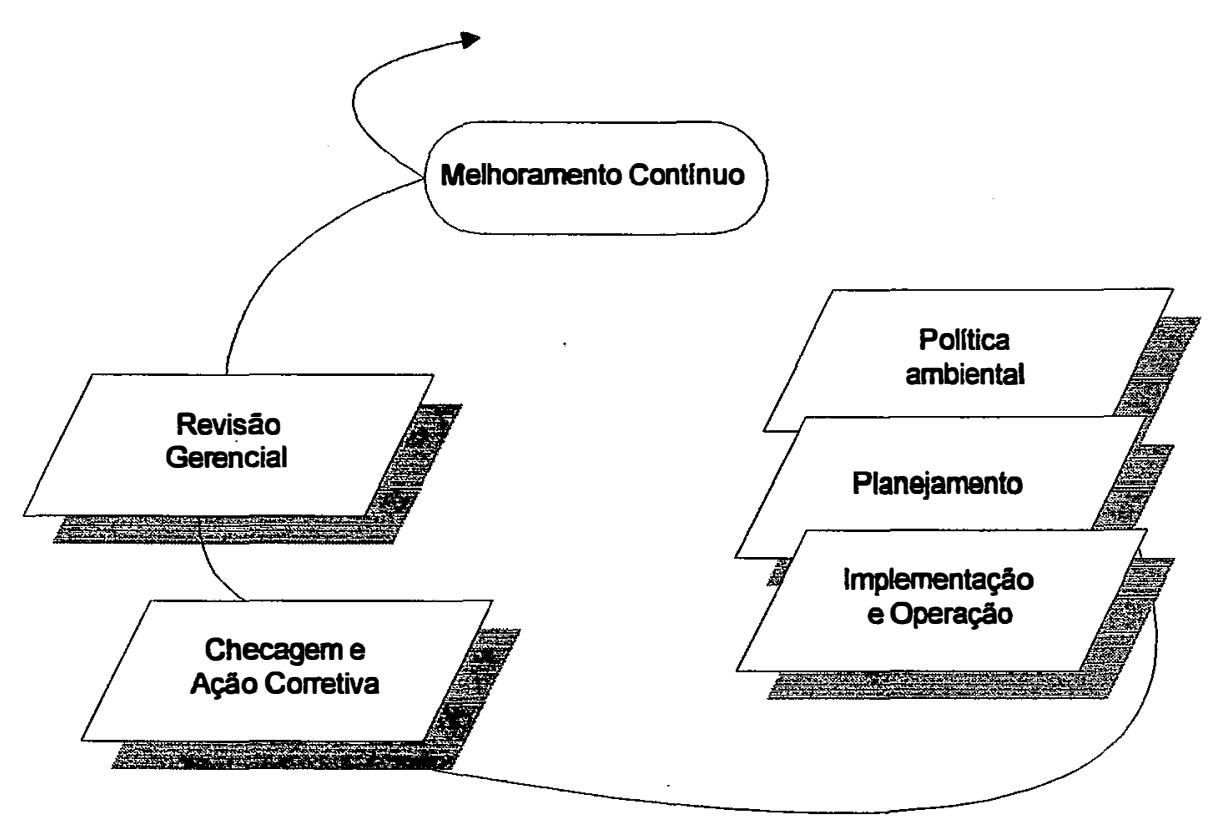

FONTE: Kiekens (1997) 


\section{REFERÊNCIAS BIBLIOGRÁFICAS}

ALLIANCE FOR ENVIRONMENTAL TECHNOLOGY (AET). Trends in World Bleached Chemical Pulp Production: 1990 - 1998. http://www.aet.org/science/aet_trends_1999.html (20 de dezembro de 1999)

ANDRADE, J. C. S et al. Uma análise do processo de formulação das estratégias sócioambientais pelo viés da teoria dos jogos: o caso da Aracruz Celulose S.A. In: 30 Congresso Anual de Celulose e Papel da ABTCP, São Paulo, 1997. Anais. São Paulo: 1997, p. $475-489$.

Annual Review. Pulp \& Paper, vários números

ARACRUZ. hitp//:www.aracruz.com.br (15 de abril de 2000)

BACHA, C. J. C. A expansão da silvicultura no Brasil. Rev. Bras. de Economia, v. 45, n. 1, p 145-168, jan./mar. 1991

BACHA, C. J. C. ; SILVA, M. M. P. Evolução do reflorestamento no Brasil - impactos de políticas públicas e tendências. Piracicaba: IICA/ACA, 1999. 59p. (Relatório do contrato 1302/98)

BAIN, J. S. Industrial organization. 2.ed. New York: John Wiley \& Sons, 1968. 678p.

BEAL, Michael. Clearing up the bleach market. Pulp and Paper International, p.3739, Oct. 1997. 
BNDES. A participação do sistema BNDES na evolução do setor de papel e celulose no Brasil. Rio de janeiro : DERIN/BNDES, 1991. 106p.

- Estudo da competitividade da indústria brasileira. Campinas: IE/UNICAMP, IEI/UFRJ, FDC, FUNCEX, 1993. 76p.

- _- As exigências sociais e ambientais para as novas fábricas de celulose no Brasil. /Apresentado ao Sixth Global Conference on Paper \& the Environment. mimeo

BULHÕES, Myrian S. Os lucros estão de volta. Conjuntura Econômica, p. 39-42, Ago. 1995

CANUTO, O. Aprendizado tecnológico na industrialização tardia. Economia e Sociedade, n. 2, p. $171-189$, ago./1993

CARLTON, B. \& PERLOFF, J. Modern industrial organization. Harper Collins, 1990. 973p.

CASTILHO, M R. Barreiras não-tarifárias: o caso da imposição de restrições ambientais sobre as exportações brasileiras de papel e celulose. Rio de Janeiro, 1994. 106 p. Dissertação (M.S.) - UFRJ

CITICORP. Brazilian pulp and paper industry. New York: 1998. 114p.

CORAZZA, R. I. Inovação tecnológica e demandas ambientais: notas sobre o caso da indústria brasileira de papel e celulose. Campinas, 1996. 151 p. Dissertação (M.S.) - Unicamp

COUTINHO, L. A terceira revolução industrial e tecnológica. Economia e Sociedade, n. 1, p. $69-87$, ago./1997

D'ALESSIO, S. P. Fornecedores apostam na recuperação de preços. Celulose \& Papel, n.66, p. 14-16, 1999.

FAO. Faostat, hHtp//iwuw.apps.fao.org (06 de novembro de 1999) 
FAO. Forestry statistical yearbook (vários anos).

FONSECA, M. G. D. A indústria de papel e celulose no Brasil: um estudo sobre competitividade e meio ambiente. Informações Econômicas, v. 25, n. 10, p. 11 32 , out/1995

FORWARD STEWARDSHIP COUNCIL. FSC principles and criteria. http://www.fscoax.org, (20 de dezembro de 1999).

GARCIA, L. A. F. A organização industrial da moagem de trigo no Brasil. Piracicaba, 1997. 158p. Dissertação (M.S.) - ESALQ/USP

GONÇALVES, Patrícia C. Sob os efeitos da crise asiática. Conjuntura Econômica, p.65-67, Ago. 1998

GREENPEACE. Pulp and paper. http://www.greenpeace.org/ -toxics/reports/gopherreports/chlora3.txt (05 de março de 200))

GRINBAUM, Ricardo. Papel e celulose viram o jogo em 99. Folha de São Paulo, Dinheiro, São Paulo, 3 nov. 1999. p. 1

HAGUENAUER, L. Competitividade: conceitos e medidas: uma resenha da bibliografia recente com ênfase no caso brasileiro. Rio de Janeiro, Texto para Discussão n. 211, IEI/UFRJ, 1989

HASSE, Geraldo. Investida da Aracruz na exportação de madeira. Gazeta Mercantil, São Paulo, 4 ago. 1999 p. C-6.

HIGASHI, H. Y. Estratégias tecnológicas das empresas líderes na indústria brasileira de papel. Campinas, 1993. 196 p. Dissertação (M.S.) - IE/UNICAMP

IMF. International Financial Statistics (compact disc).

INTERNATIONAL PAPER. The ECF vs. TCF pulp bleaching debate: pulp facts, pulp fiction http://mww.internationalpaper.com/our_world/ecf_frame.html (03 de março de 2000) 
KENNY, Jim. More mergers to come in the race to consolidate. Pulp and Paper International, p. 21-28, Set. 1998.

KIEKENS, Jean-Pierre. Certification: international trends and forestry and trade implications. Bruxelas: Environmental Strategies Europe, 1997. 41 p.(Estudo apresentado ao Ministério do Meio Ambiente, dos Recursos Naturais e da Agricultura da Região de Wallonne - Bélgica).

$\mathrm{KOCH}, \mathrm{J} . \mathrm{V}$. Industrial organization and prices. 2.ed. New Jersey: Prentice-Hall, $1980,504 p$.

KRUGMAN, P. R. Industrial organization and international trade. In: Schmalensee, R. \& Willig, R. (Ed.) Handbook of industrial organization. Amsterdam: Elsevier, 1992 cap. 20, p. $1179-1223$

LEIVA, R. Z. Em busca de uma metodologia de avaliação da competitividade internacional em setores industriais. São Paulo, 1994. 205 p. Dissertação (M.S) FEA/USP

MACEDO, A. R. P. ; MATTOS, R. L. G. A trajetória de crescimento dos principais produtores brasileiros de papel e celulose - 1970/94. BNDES Setorial, n. 3, Mar. 1996.

MACEDO, A. R. P.; VALENÇA, A. C. V. ; LEITE, E. T. Celulose de mercado. BNDES Setorial, n. 1, p.68 - 79, Jul. 1995.

MACEDO, A. R. P.; VALENÇA, A. C. V. ; MATTOS, R. L. G. Indústria brasileira de celulose e papel: necessidade de investimentos. Rio de Janeiro: BNDES, Maio 1998. 14p. (Informe Setorial - Produtos Florestais)

MACEDO, A. R. P.; VALENÇA, A. C. V. Reciclagem de papel. BNDES Setorial, n. 2, p.5 - 22, Dez. 1995.

A crise asiática e o setor de celulose e papel no Brasil. Rio de Janeiro: BNDES, Mar. 1998. 5p. (Informe Setorial 14) 
MARION FILHO, J. P. A evolução e a organização recente da indústria de móveis nos estados de Santa Catarina e Rio Grande do Sul. Piracicaba, 1997. 151p. Tese (Doutorado) - ESALQ/USP

MASON, E. S. Price and production policies of large-escale enterprise. The American Economic Review, v.29, n.1p. 61 - 74, mar./1939

MATTOS, R. L. G.; VALENÇA, A. C. V. A reestruturação do setor de papel e celulose. BNDES Setorial, n. 10, p.253 - 268, Set. 1999.

MEDEIROS, V. X. ; FONTES, R. M. O. Competitividade das exportaçōes brasileiras de celulose no mercado internacional. R. Econ. Sociol. Rural, v. 32, n.2, p. 105-121, abr./jun. 1994

MENDONÇA JORGE, Maurício O. Emergência e consolidação do "padrão eucalipto" na indústria brasileira de celulose de mercado. Campinas, 1992. 166p. Dissertação (M.S.) - IE/UNICAMP

MICHELI, Jordy. Fin de siglo: construcción del mercado ambiental global. Comercio exterior, v. 50, n. 3, p. 187-195, mar. 2000

MORAES, M. A. F. D. A indústria de madeira preservada no Brasil: um estudo de sua organização industrial. Piracicaba, 1996. 154p. Dissertação (M.S.) - ESALQ/USP

NAHUZ, M. A. R. Certificação ambiental de produtos. O papel. p. $15-22$, abr./1995.

PALADINO, G. G. Papel, técnica e capital: estudo sobre a evolução e mutação nos processos de trabalho e de produção do papel e análise do desenvolvimento do setor papeleiro no Brasil. Curitiba, 1985. 364 p. Dissertação (M.S.) - UFMG

PIZZOL, S. J. S. \& BACHA, C. J. C. Evolução, estrutura e desafios da indústria de celulose no Brasil. Preços Agrícolas, ano XII, n. 137, p. 3 - 13, mar./1998 
PORCILE, J. G. Tecnologia, transformação industrial e comércio internacional: uma revisão das contribuições neo-schumpterianas, com particular referência para a América Latina. Campinas, 1989. Dissertação (M.S.) - IE/UNICAMP

PORTER, Michael E. Estratégia competitiva: técnicas para análise de indústrias e da concorrência. 6. ed. Rio de Janeiro : Campus, 1991. 362p.

RAPOSO, Márcia. Cortes na produção de celulose reativam preços. Gazeta Mercantil, São Paulo, 24, 25 e 26 abr. 1999. p.C-1.

RÊGO, Elba C. L. Do Gatt à OMC: o que mudou, como funciona e para onde caminha o sistema multilateral de comércio. Revista do BNDES, v. 3, n. 6, p. 3-22, Dez. 1996.

ROXO, Carlos Alberto. Certificação florestal como instrumento de mercado Desenvolvimentos recentes e desafios futuros. /Apresentado à $40^{\circ}$ Sessão do Comitê Consultivo de Produtos de Madeira e Papel, São Paulo, 1999/

SANTOS, D. F. Estrutura, conduta e desempenho do mercado exportador brasileiro de café cru em grão e do café solúvel. Viçosa, 1996. 72p. Dissertação (M.S.) - UFV

SCHERER, F. M. \& ROSS, D. Industrial market structure and economic performance. 3.ed. Boston: Houghton Miffin, 1990. 713p.

SCHWARZER, H. A proposta da CEPAL para a década de 90: a transformação produtiva com eqüidade social. Rev. de Economia, n. 18, p. 27 - 59, 1994

SILVA, Maroni J. A gestão ambiental no setor de celulose e papel. Celulose \& Papel, n. 54, p.11-15, Mar-Abr, 1997.

SILVA, Ricardo ; BRAVO, Maria A. M. Comércio exterior e meio ambiente. Revista do BNDES, v. 1, n. 1, p. 113-128, Jun. 1994. 
SILVA, W. M. Tendências no mercado mundial de celulose: a regulação ambiental e o desenvolvimento tecnológico. Rio de Janeiro, 1995. 136 p. Dissertação (M.S.) UFRRJ

SOTO, B. F. A. Da indústria do papel ao complexo florestal no Brasil: o caminho do corporativismo tradicional ao neocorporativismo. Campinas, 1992. Tese (Doutorado) - UNICAMP

TAVARES, Rita. Grupo Orsa assume controle acionário do Jari. Estado de São Paulo. Economia, São Paulo, 23 dez. 1999 p.B-9

VALENÇA, A. C. V.; MATTOS, R. L. G. Celulose e pastas para fabricação de papel. Rio de Janeiro: BNDES, Jan. 1999a. 10p. (Informes setoriais - Produtos Florestais)

Papel e celulose: comércio exterior. Rio de Janeiro: BNDES, Jul./1999b, 12p. (Informes setoriais - Produtos Florestais)

WEBB, Leslie. Eco-labels stuck on search for common standards. Pulp and Paper International, p.39-43, Nov. 1994.

WYMAN, Vic. Mills look to clean up and to boost profits. Pulp and Paper International, p.42-43, Mar. 1995.

ZAEYEN, A. Estrutura e desempenho do setor de papel e celulose no Brasil. Rio de janeiro, 1986. 199 p. Dissertação (M.S.) - IEI/UFRJ. 